\title{
Taxonomic revision of the Andean genus Eulibitia Roewer, 1912 (Arachnida, Opiliones, Cosmetidae), with the description of five new species
}

\author{
Miguel MEDRANO ${ }^{1, *} \&$ Adriano B. KURY ${ }^{2}$ \\ 1,2 Departamento de Invertebrados, Museu Nacional/UFRJ, Quinta da Boa Vista, \\ São Cristóvão, 20940-040, Rio de Janeiro - RJ, Brazil. \\ *Corresponding author: miangelmed@gmail.com \\ ${ }^{2}$ Email: adrianok@gmail.com \\ ${ }^{1}$ urn:1sid:zoobank.org:author:C7F7D4CF-F9B2-44AF-9F03-86278ADBD4F2 \\ ${ }^{2}$ urn:1sid:zoobank.org:author:60FAE1F8-87F7-4A5F-BE78-BEB25BC4F898
}

\begin{abstract}
The genus Eulibitia was described by Roewer including three species from Colombia and Ecuador: Eulibitia maculata Roewer, 1912, E. annulipes Roewer, 1912 and E. sexpunctata Roewer, 1914. Herein, the genus is revisited and only the type species, Eulibitia maculata Roewer, 1912 is maintained from the previous configuration. Eulibitia sexpunctata is transferred to Ambatoiella MelloLeitão, 1943 and E. annulipes is considered as Cosmetinae incertae sedis. Acromares lateralis Goodnight \& Goodnight, 1943 and Paramessa castanea (Sørensen, 1932) are here considered junior subjective synonyms of Messatana scalaris (Sørensen, 1932) and Eulibitia maculata, respectively. Brachylibitia Mello-Leitão, 1941, currently a junior synonym of Platymessa, is regarded as a synonym of Eulibitia. Platymessa Mello-Leitão, 1941, with two species, and the monotypic genera Messatana Strand, 1942 and Paramessa Mello-Leitão, 1933, are synonymized with Eulibitia Roewer, 1912, yielding the following new combinations: Eulibitia ectroxantha (for Brachylibitia ectroxantha Mello-Leitão, 1941), E. h-inscriptum (for Platymessa h-inscripta Mello-Leitão, 1941) and E. scalaris (for Libitia (Messa) scalaris Sørensen, 1932). Eulibitia is re-diagnosed and five new species are described: E. castor sp. nov., E. pollux sp. nov., E. clytemnestra sp. nov., E. leda sp. nov. and E. helena sp. nov. A key to the nine Eulibitia species is presented; the morphology of Eulibitia is compared with that of Libitia, Libitiella and Ambatoiella.
\end{abstract}

Keywords. Laniatores, Gonyleptoidea, Colombia, Ecuador, Neotropics.

Medrano M. \& Kury A.B. 2017. Taxonomic revision of the Andean genus Eulibitia Roewer, 1912 (Arachnida, Opiliones, Cosmetidae), with the description of five new species. European Journal of Taxonomy 357: 1-55. https://doi.org/10.5852/ejt.2017.357

\section{Introduction}

Opiliones are the third most diverse order of arachnids, comprising more than 6500 species and superseded only by Acari and Araneae (Harvey 2002). With more than 4200 species, Laniatores Thorell, 1876 is 
the most diverse suborder of harvestmen (Kury 2016a), possessing a convoluted and obscure taxonomy (Kury 2003). Gonyleptoidea is by far the largest superfamily of Laniatores, featuring more than 2000 species distributed mainly in the Neotropics. The internal relationships in Gonyleptoidea are rather fluid, with many recent rearrangements (e.g., Kury 2014; Pinto-da-Rocha et al. 2014), but the family Cosmetidae is universally recognized as a clade. Cosmetidae is supported among many other features by having the pedipalpus with a flattened femur, spoon-shaped tibia (Kury \& Pinto-da-Rocha 2007) and a defensive behavior known as leg dabbing (character 46 in Caetano \& Machado 2013, although they only used the species Gryne coccinelloides (Mello-Leitão, 1935) and Vonones sayi (Simon, 1879)).

The German author C.-F. Roewer (e.g., 1912, 1923) created a system of diagnosing genera based on immediately recognizable tarsal counts and the armature of the ocularium, dorsal scutum and free tergites. This has been widely called the "Roewerian system" (starting with Henriksen 1932: 222). All these characters have been repeatedly demonstrated to be variable individually, sexually dimorphic and of dubious interpretation (e.g., Piza 1942; Soares \& Soares 1985; Kury 1990). Roewer ignored most of the potentially useful diagnostic features (e.g., shape of dorsal scutum (DS) outline, spot pattern in DS, armature of basal segments of legs, shape of glans, chaetotaxy of penis ventral plate) in favor of the above cited character sets, resulting in obviously artificial assemblages.

The Roewerian system affected particularly the Cosmetidae because the external morphology in many species is very conservative and there are no suprageneric subdivisions which would turn their 700 species diversity (Kury 2013) into manageable units. The historical subfamilies proposed, Discosomaticinae and Cosmetinae, have been deemed not to be monophyletic groups (see Ferreira \& Kury 2010). The present project attempts to clarify a part of the grim history of the Andean Cosmetidae by revising a group of small Opiliones, here grouped and diagnosed as the genus Eulibitia Roewer, 1912. Additionally, the genus was compared morphologically with species of apparently related genera, such as Libitia Simon, 1879, Libitiella Roewer, 1947, Ambatoiella Mello-Leitão, 1943 and Taito Kury \& Barros, 2014.

\section{Taxonomic background}

The Andean species of Cosmetidae were only summarily described in the Roewerian literature, dating mainly from the early 20th century. The current generic allocations of the species are is most cases unsatisfactory.

The genus Eulibitia was erected by Roewer (1912) for the species E. maculata Roewer, 1912 (from Colombia) and E. annulipes Roewer, 1912 (from the Pacific coast of Ecuador), which share the following characteristics: (1) body flattened and legs strong and short, (2) no sexual dimorphism in chelicerae or legs, (3) scutal areas I-III unarmed and IV-V with a pair of paramedian tubercles, and (4) tarsal counts: 6/>6/6/6. Later, Roewer (1914) described a third species from Ecuador, Eulibita sexpunctata Roewer, 1914.

Sørensen (in Henriksen 1932) created the subgenus Messa, inside Libitia Simon, 1879, grouping the species L. argentina (Sørensen, 1884) and L. paraguayensis (Sørensen, 1884), and described two new ones: L. scalaris and L. castanea, both from Bogotá, Colombia. Nevertheless, the name Messa was not valid until Mello-Leitão's (1933) assignation of type species and description (Kury \& Alonso-Zarazaga 2011). Mello-Leitão (1933) transferred the four species of the subgenus to four different genera, as follows: L. paraguayensis to Metalibitia Roewer, 1912, L. argentina to Paralibitia Roewer, 1912 (currently synonymized with Metalibitia), L. scalaris to Messa Mello-Leitão, 1933 and L. castanea to the newly created Paramessa Mello-Leitão, 1933. Ultimately, Strand (1942) replaced the name Messa with Messatana Strand, 1942 to avoid a conflict with the senior homonym Messa Leach, 1817 (Hymenoptera). 
Goodnight \& Goodnight (1942a) described the genus Acromares Goodnight \& Goodnight, 1942 for the Mexican species A. banksi Goodnight \& Goodnight, 1942, characterized by the presence of two spines in the IV scutal area. In two later papers (Goodnight \& Goodnight 1942b, 1943), they described two more species: A. vittatum Goodnight \& Goodnight, 1942 from Belize and A. lateralis Goodnight \& Goodnight, 1943 from Colombia. However, the Colombian species differs from the others by having two tubercles on the porterior margin of DS instead of scutal area IV, showing no apparent congeneric relation. This is reinforced by the disjointed distribution of this species compared to the other two.

Mello-Leitão (1941) described the monotypic genus Brachylibitia Mello-Leitão, 1941 and the genus Platymessa Mello-Leitão, 1941 with two species P. h-inscripta Mello-Leitão, 1941 and P. nigrolimbata Mello-Leitão, 1941; both genera were described from the Andes of Colombia. In a later work, Roewer (1963) described a third species, P. transversalis Roewer, 1963 from Cajamarca, Peru. Finally, Medrano \& Kury (2016) considered $P$. nigrolimbata as a junior synonym of $P$. h-inscriptum, synonymized Brachylibitia with Platymessa, transferring $B$. ectroxantha to Platymessa and $P$. transversalis to Chusgonosbius Roewer, 1952, yielding the new combinations P. ectroxantha and C. transversalis, rendering Platymessa a monotypic genus.

\section{Material and methods}

Although the taxonomy of Cosmetidae is still unstable, an effort has been made here to provide a diagnosis of Eulibitia comparing it with genera that are morphologically similar (see Discussion). Therefore, a choice of the genera for comparison was made among cosmetids with the following characteristics: (1) small body, not exceeding $5 \mathrm{~mm}$ in length; (2) monomorphic chelicerae; (3) flat body in lateral view, that is, without large tubercles or spines in the scutal areas; and (4) short legs, femur length not exceeding twice the body length.

Abbreviations of depository collections are as follows:

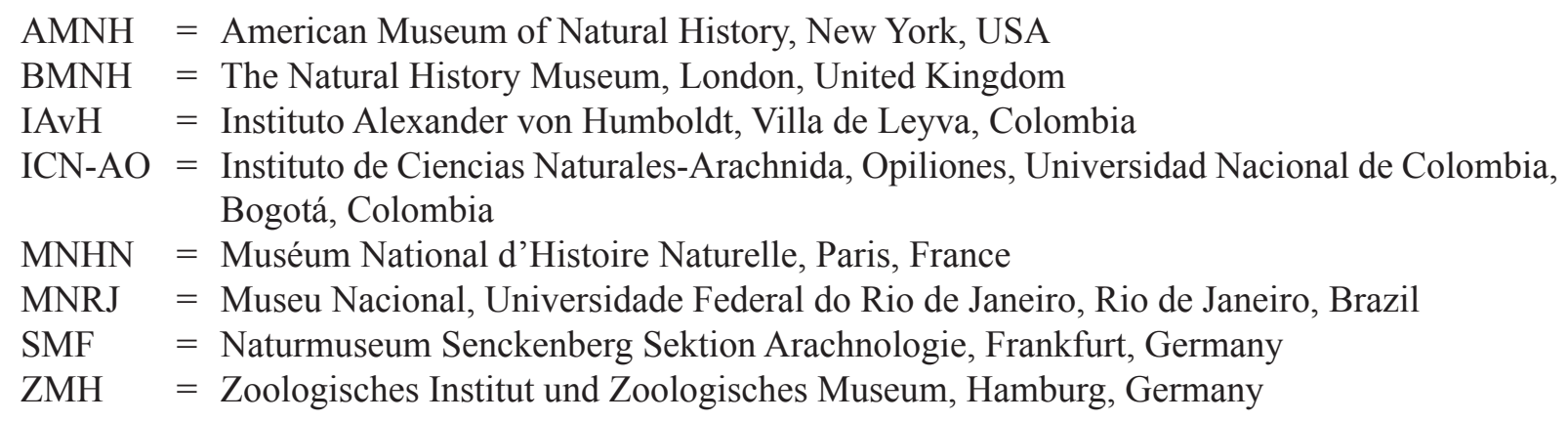

The types of Sørensen were photographed in the Sackler Biodiversity Imaging Laboratory of BMNH through their image capture system.

Descriptions follow Medrano \& Kury (2016) for external morphology; DaSilva \& Gnaspini (2009) for the dorsal armature; Kury \& Medrano (2016) for the outline of the dorsal scutum; Kury \& Villarreal (2015) and Medrano \& Kury (2016) for the chaetotaxy of macrosetae on the ventral plate of the penis; and Kury (2016b) for terminology of the microsetae. The order of numbers of tarsomeres in tarsus I to IV is from left to right side (figures in parentheses denote number of tarsomeres only in the distitarsi I-II). The caruncle (Ferreira \& Kury 2010), also called wattle (Kury \& Barros 2014), is the distal serrate crest of the stylus of Cosmetidae and closely related families that resembles a cockscomb. All measurements are in millimeters unless otherwise noted. The color patterns were based only on specimens preserved in $70 \%$ ethanol, using the standard names of the 267 color centroids of the NBS/IBCC Color System (Jaffer 2001-) as explained in Kury \& Orrico (2006). 
The following abbreviations are used:

$$
\begin{aligned}
\mathrm{AL} & =\text { abdominal scutum length } \\
\mathrm{AW} & =\text { abdominal scutum width } \\
\mathrm{CL} & =\text { carapace length } \\
\mathrm{CW} & =\text { carapace width } \\
\mathrm{Cx} & =\text { coxa } \\
\mathrm{DS} & =\text { dorsal scutum } \\
\mathrm{Fe} & =\text { femur } \\
\mathrm{MS} & =\text { macrosetae } \\
\mathrm{Mt} & =\text { metatarsus } \\
\mathrm{Pp} & =\text { pedipalpus } \\
\mathrm{Ta} & =\text { tarsus } \\
\mathrm{Ti} & =\text { tibia } \\
\mathrm{Tr} & =\text { trochanter } \\
\mathrm{VP} & =\text { ventral plate }
\end{aligned}
$$

Information on the material examined enclosed in square brackets [ ] was obtained during this study and is not part of the original label data. The geographical coordinates were obtained directly from the labels (unless in square brackets).

The specimens were submerged in 70\% alcohol on blue sand to improve contrast and avoid movement. Dry specimens were necessary to illustrate tubercles of small size. The illustrations were made using a stereo microscope with a camera lucida and digitalized using the software Inkscape v. 0.48. Photographs were taken with a Sony Cybershot DSC-V1 camera attached to the stereo microscope. The software package COMBINEZ, version COMBINEZP (Hadley 2015), was used to create composite images with extended depth of field. The resulting images were edited with Photoshop CS5. The plates were prepared in Inkscape for line drawings and Corel Draw X7 for photographs.

The treatment of the male genitalia follows Acosta et al. (2007). Drawings were made in Inkscape based on the series of photographs taken using a stereo microscope equipped with a digital camera and composed with COMBINEZ. Scanning electron microscopy was carried out with a JEOL JSM-6390LV at the Center for Scanning Electron Microscopy of MNRJ, with an accelerating voltage of $10 \mathrm{kV}$ after sputter-coating with gold-palladium.

Geographical coordinates for localities were obtained from Geonames (2015) when they were not present on the labels. The distribution map was produced using ESRI ARCGIS v. 10 software. Localities are referred to the WWF Terrestrial Ecoregions of the World (Olson et al. 2001, here abbreviated as WWF).
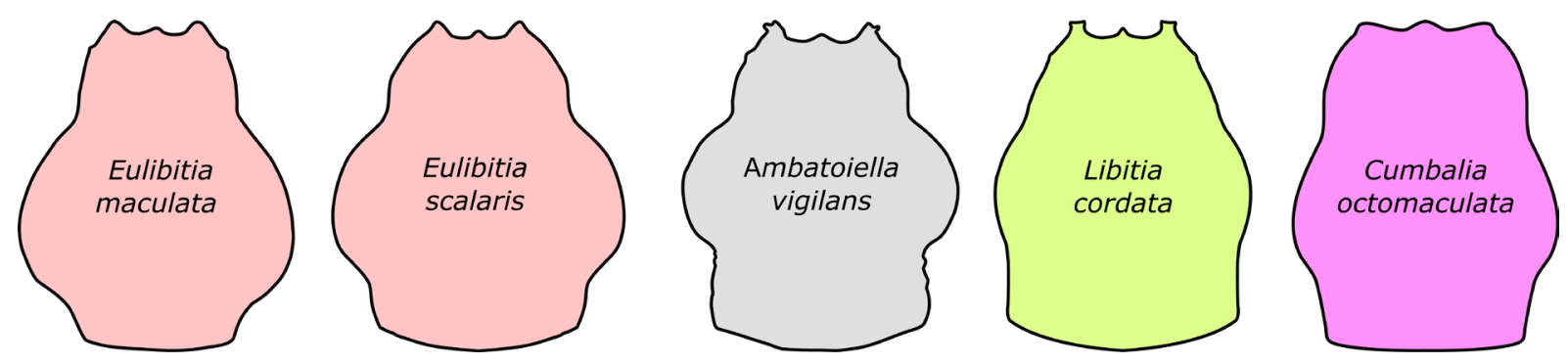

Fig. 1. Schematic outline of DS of Eulibitia Roewer, 1912 (beta), Ambatoiella Mello-Leitão, 1943 (alpha), Libitia Simon, 1879 (alpha) and Cumbalia Roewer, 1963 (kappa). 


\title{
Results
}

\author{
Class Arachnida Lamarck, 1801 \\ Order Opiliones Sundevall, 1833 \\ Suborder Laniatores Thorell, 1876 \\ Infraorder Grassatores Kury, 2002 \\ Superfamily Gonyleptoidea Sundevall, 1833 \\ Family Cosmetidae C.L. Koch, 1839 \\ Subfamily Cosmetinae C.L. Koch, 1839
}

Eulibitia Roewer, 1912

Eulibitia Roewer, 1912: 16 (type species: Eulibitia maculata Roewer, 1912, by original designation).

Libitia (Messa) Sørensen in Henriksen, 1932: 412 (junior homonym of Messa Leach, 1817 (Hymenoptera) and unavailable name because no type species was designated). Syn. nov.

Messa Mello-Leitão, 1933: 107, 112 (available because a type species was designated and a description provided, but still invalid due to homonymy; type species: Libitia (Messa) scalaris Sørensen, 1932, by original designation). Syn. nov.

Paramessa Mello-Leitão, 1933: 109 (type species: Libitia (Messa) castanea Sørensen, 1932, by original designation). Syn. nov.

Brachylibitia Mello-Leitão, 1941: 166 (junior subjective synonym of Cynorta C.L. Koch, 1839 according to Goodnight \& Goodnight (1953: 38); synonymy disclaimed by Kury (2003); junior subjective synonym of Platymessa Mello-Leitão, 1941 according to Medrano \& Kury (2016); type species: Brachylibitia ectroxantha Mello-Leitão, 1941, by original designation). Syn. nov.

Platymessa Mello-Leitão, 1941: 167 (type species: Platymessa h-inscripta Mello-Leitão, 1941, by original designation). Syn. nov.

Messatana Strand, 1942: 398 (replacement name for Messa Mello-Leitão, 1933). Syn. nov.

Eulibitia - Roewer 1914: 127; 1923: 298; 1928: 547. — Mello- Leitão 1926: 331; 1932: 56; 1933: 106.

— Kury 2003: 60. — Pinto-da-Rocha \& Hara 2011: 10. — Medrano \& Kury 2016: 52.

Messa - Mello-Leitão 1935: 114. - Kury \& Alonso-Zarazaga 2011: 50.

Platimessa (incorrect original spelling) - Mello-Leitão 1941: 167.

Platymessa - Roewer 1963: 52. — Kury 2003: 81. — Medrano \& Kury 2016: 54.

Brachylibitia - Kury 2003: 38.

Messatana - Kury 2003: 67. - Kury \& Alonso-Zarazaga 2011: 50.

Paramessa - Kury 2003: 80.

\section{Diagnosis}

Outline of the dorsal scutum beta-shaped, with coda convergent posteriorly in males and almost parallel in females; protoglyphs shallow, with well-marked lateral triangular or rounded projections (Figs 1, 6A). Posterior margin of scutum armed with two small paramedian tubercles (except for E. maculata). Areas II and IV unarmed (Figs 5-6). Yellowish white color markings of scutum as a ladder mask over dark brown background, blots dissociated sometimes to the point of having no white marking (Fig. 20A, C-H). Spot as a yellowish band on posterior margin, posterior to paramedian tubercles, sometimes dissociated medially (Figs 12A, 16A). Coxa IV entirely visible in dorsal view, reaching posterior groove of scutal area III (Figs 5A, 8A). Chelicerae (Figs 7F, 13A) monomorphic, weak, with marginal rows of acuminate tubercles of varied size on posterior border. Movable and fixed fingers with blunt teeth (Fig. 17A). Pedipalpal femur with a dorsal keel formed by a row of tubercles (Figs 10E, 17E). Legs short and strong, Fe III and IV slightly arched to the inside (Fig. 21A-C); basitarsomeres of leg I of male thicker than distitarsomeres (Fig. 2). Tarsal counts: 4-6; 6-14; 6-7; 6-9. Ventral plate of penis 
subrectangular laterally, with 6 pairs of MS, organized from base to top as follows: A1-A2, D1-D2, C1C2; and ventrally: B basally and E1-E2 distally (Figs 3, 22; contrasting with Ambatoiella and Libitia, see Fig. 4A, E). Microsetae of type T4, restricted to lateral margins of ventral side of VP as two parallel stripes from corners to MS B (Fig. 30A, C-D).

\section{Etymology}

Eulibitia: from Greek $\varepsilon \tilde{v}$ (rightful, proper, good) + pre-existing generic name Libitia (with origin obscure, but sounds like an Ancient Roman woman's name). Gender feminine. Messa: from a city name in Ancient Greece. Gender feminine. Paramessa: from Greek $\pi \alpha \rho \alpha ́$ (beside) + pre-existing genus Messa.

\section{Eulibitia leda}

$\operatorname{leg} I$

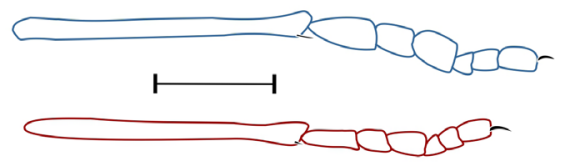

leg III
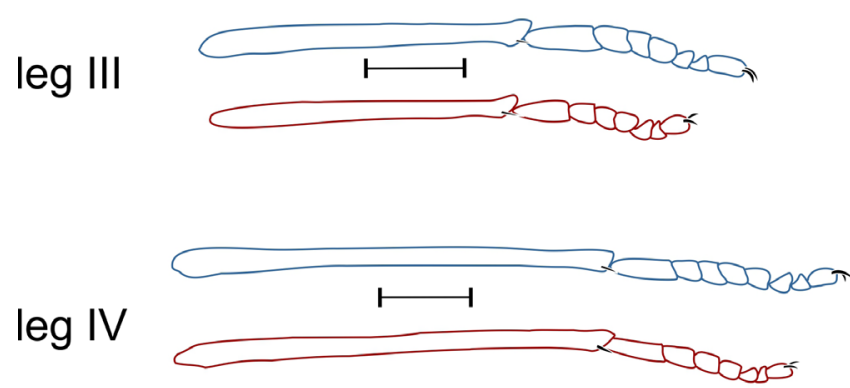

Ambatoiella vigilans

leg I

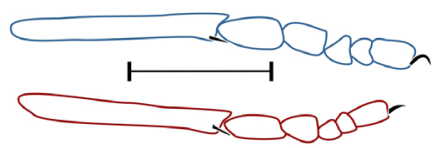

leg III

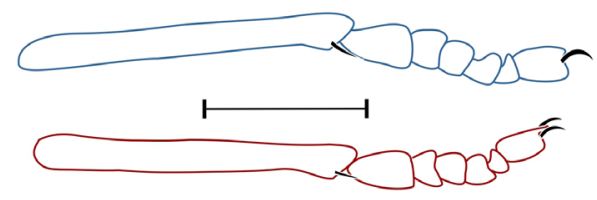

leg IV

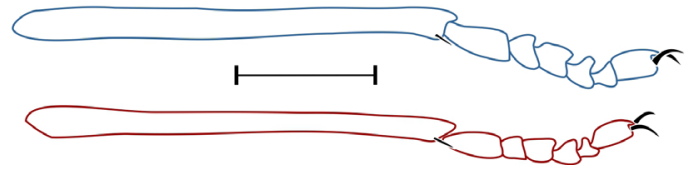

\section{Cumbalia octomaculata}
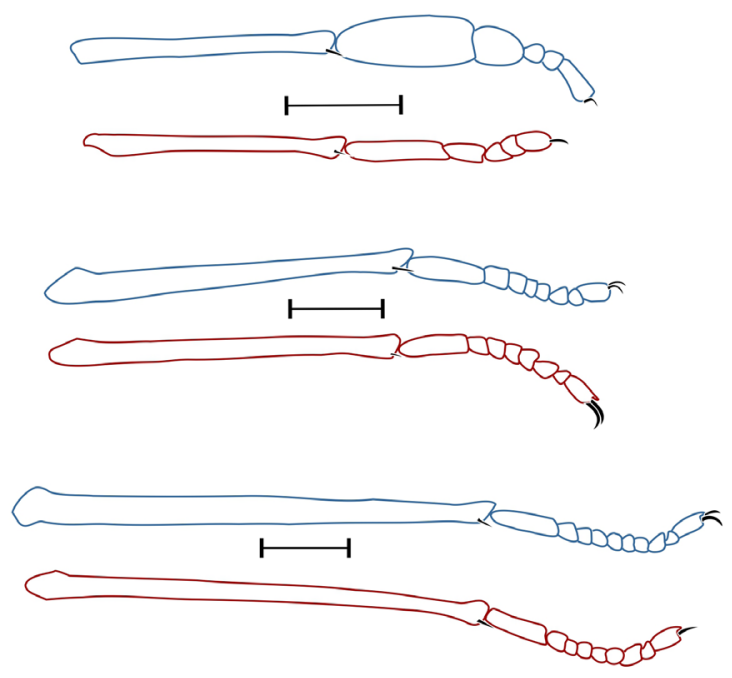

Libitia cordata
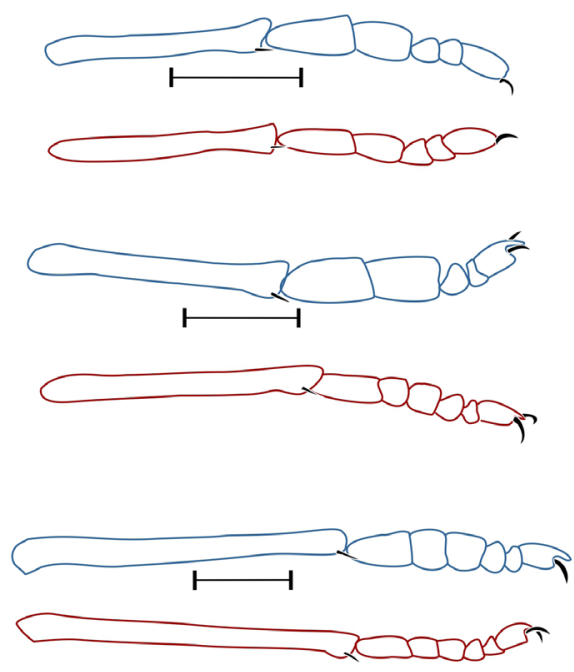

Fig. 2. Metatarsus and tarsomeres of legs I, III and IV of the cosmetine genera treated here, showing the proportions and thickening of the articles. Each pair of legs contains depiction of male above and female below. Scale bars: $1 \mathrm{~mm}$. 


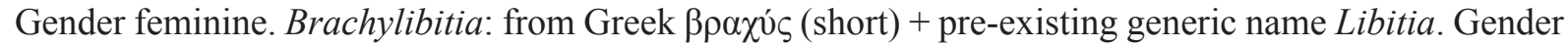
feminine. Platymessa: from Greek $\pi \lambda \alpha \tau u$ - (flattened) + pre-existing generic name Messa. Gender feminine. Messatana: variation of pre-existing genus Messa. Gender feminine.

\section{Included species}

Eulibitia maculata Roewer, 1912 (type species), E. scalaris (Sørensen, 1932) comb. nov., E. h-inscriptum (Mello-Leitão, 1941) comb. nov., E. ectroxantha (Mello-Leitão, 1941) comb. nov., E. castor sp. nov., E. clytemnestra sp. nov., E. helena sp. nov., E. leda sp. nov. and E. pollux sp. nov.

\section{Key to the species of Eulibitia (males only)}

Although no material of the species E. ectroxantha has been examined in this project, the description and illustrations provided by Mello-Leitão (1941) are sufficient and appropriated for this key, taking into account the characteristics listed for the other species in this section.

1. Scutal area I without tubercles, coxa IV without clavi inguines (Figs 8A, 9A) …..........................2

- Scutal area I with two paramedian tubercles, coxa IV with clavi inguines (Figs 12A, 16A) ..............5

2. Scutal area III with two paramedian tubercles .......E. ectroxantha (Mello-Leitão, 1941) comb. nov.

- Scutal area III without two paramedian tubercles (Figs 9A, 20A)

3. Scutum entirely unarmed (Figs 19, 20A)

E. maculata Roewer, 1912

- Posterior margin of scutum with two paramedian tubercles (Fig. 20A) .4

4. Posterior margin of scutum with two paramedian tubercles, separated and rounded (Fig. 8A-B); lateral margins of DS smooth (Fig. 9A); penial MS D2 large and straight (Fig. 9B-C)

E. clytemnestra sp. nov.

- Posterior margin of scutum with paramedian tubercles, contiguous and acuminate (Fig. 23A); lateral margins of DS with an irregular row of tubercles (Fig. 24A); penial MS D2 minute (Fig. 26B)

E. pollux sp. nov.

5. Ladder mask reaching lateral margins of DS (see Medrano \& Kury 2016: figs 10-18)

E. h-inscriptum (Mello-Leitão, 1941) comb. nov.

- Ladder mask confined to mesotergum (Fig. 28C-H)

6. Posterior margin of scutum with two acuminate paramedian tubercles slanted backward (Fig. 5E) E. castor sp. nov.

- Posterior margin of scutum with two rounded, erect paramedian tubercles (Figs 11E, 15E) ......7

7. Ladder mask overflowing the scutal grooves to reach areas I, II and III (Figs 11, 12A); femur IV straight, with a large dorso-apical spine (Fig. 12C-D)

E. helena sp. nov.

- Ladder mask confined to the scutal grooves (Figs 15A, 16A); femur IV curved, without a large dorso-apical tubercle or spine (Fig. 17G-I)

8. Coda short, with constriction poorly marked, dorsal apophysis of coxa IV acuminate and with few minute granules (Figs 15A, 16A), patella of pedipalpus with a mesal keel without tubercles (Fig. 17F) E. leda sp. nov.

- Coda large, with constriction well marked, dorsal apophysis of coxa IV rounded and widely granulated (Figs 27A, 28A), patella of pedipalpus with a mesal keel with a row of small setiferous tubercles (Fig. 29E) E. scalaris (Sørensen, 1932) comb. nov. 
Eulibitia castor sp. nov. urn:lsid:zoobank.org:act:954AC9A9-0ECB-4790-82D8-AEDE8D09C14E

Figs $5-7,34$

\section{Diagnosis}

Paramedian tubercles of areas I, III and posterior margin of scutum acuminate (Fig. 5E), tubercles of posterior margin higher than wide and slanted backwards (Fig. 5A, D-E). Ladder mask only present in the scutal groove between areas I and II (Fig. 6A). Coda short and mid-bulge symmetrical (Fig. 6A), clavi inguines composed of two tubercles. DS shape is very similar to that in E. pollux sp. nov., but differs because it is slightly more slender and the paramedian tubercles of the posterior margin are separated, with independent basis.

\section{Etymology}

Noun in apposition of Castor, son of Leda and Zeus, and twin of Pollux, from Greek mythology. Referring to the fact that this species and E. pollux sp. nov. are very similar to each other like the twins Castor and Pollux.

\section{Material examined}

\section{Holotype}

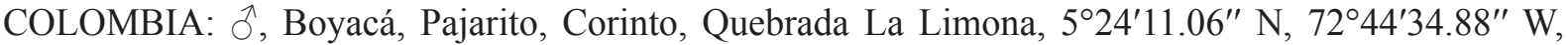
2 Sep. 1981, I. de Arévalo leg. (ICN-AO 79).
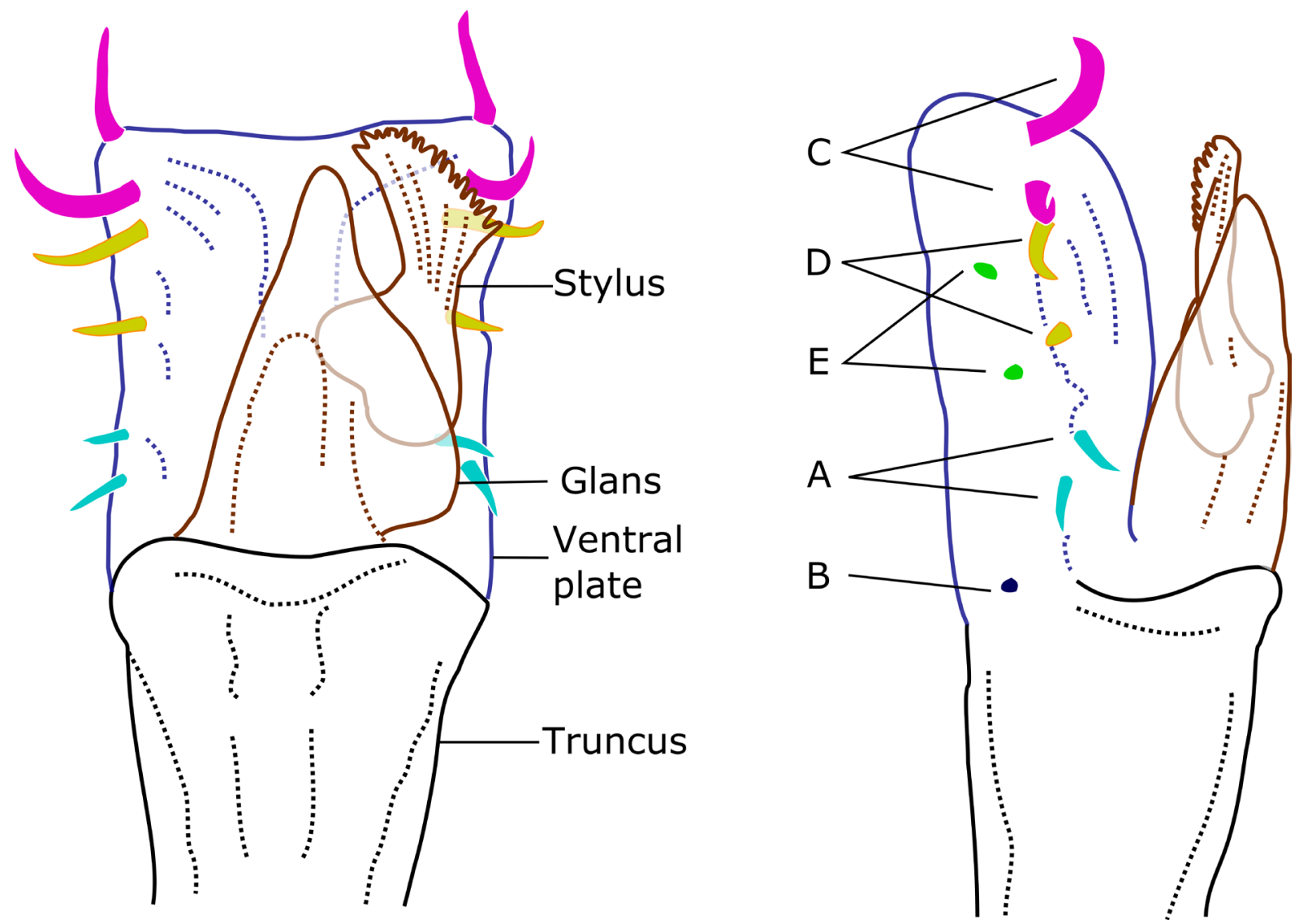

Fig. 3. Penis of Eulibitia maculata Roewer, 1912 (ICN-AO 875), dorsal and lateral view (from left to right) showing parts and interpretation of macrosetae, labeled with letters A-E. 


\section{Description}

\section{Male}

Measurements. $\mathrm{CL}=1.97, \mathrm{AL}=3.37, \mathrm{CW}=3.20, \mathrm{AW}=4.86, \mathrm{Fe} \mathrm{IV}=5.51, \mathrm{Ti} \mathrm{IV}=3.97$.

Dorsum (Figs 5, 6A). Dorsal scutum beta-shaped, with symmetrical mid-bulge. Areas I, III and posterior margin of scutum with two paramedian acuminate tubercles. Lateral margins with irregular row of minute granules at mid-bulge. Posterior margin of scutum with row of small tubercles. Tergites with row of small tubercles and anal operculum finely granular.

VENTER (Fig. 5C-D). Free sternites finely granular; coxae II-IV finely and uniformly granular; coxa I with longitudinal row of tubercles and smooth area corresponding to lace area of pedipalp.
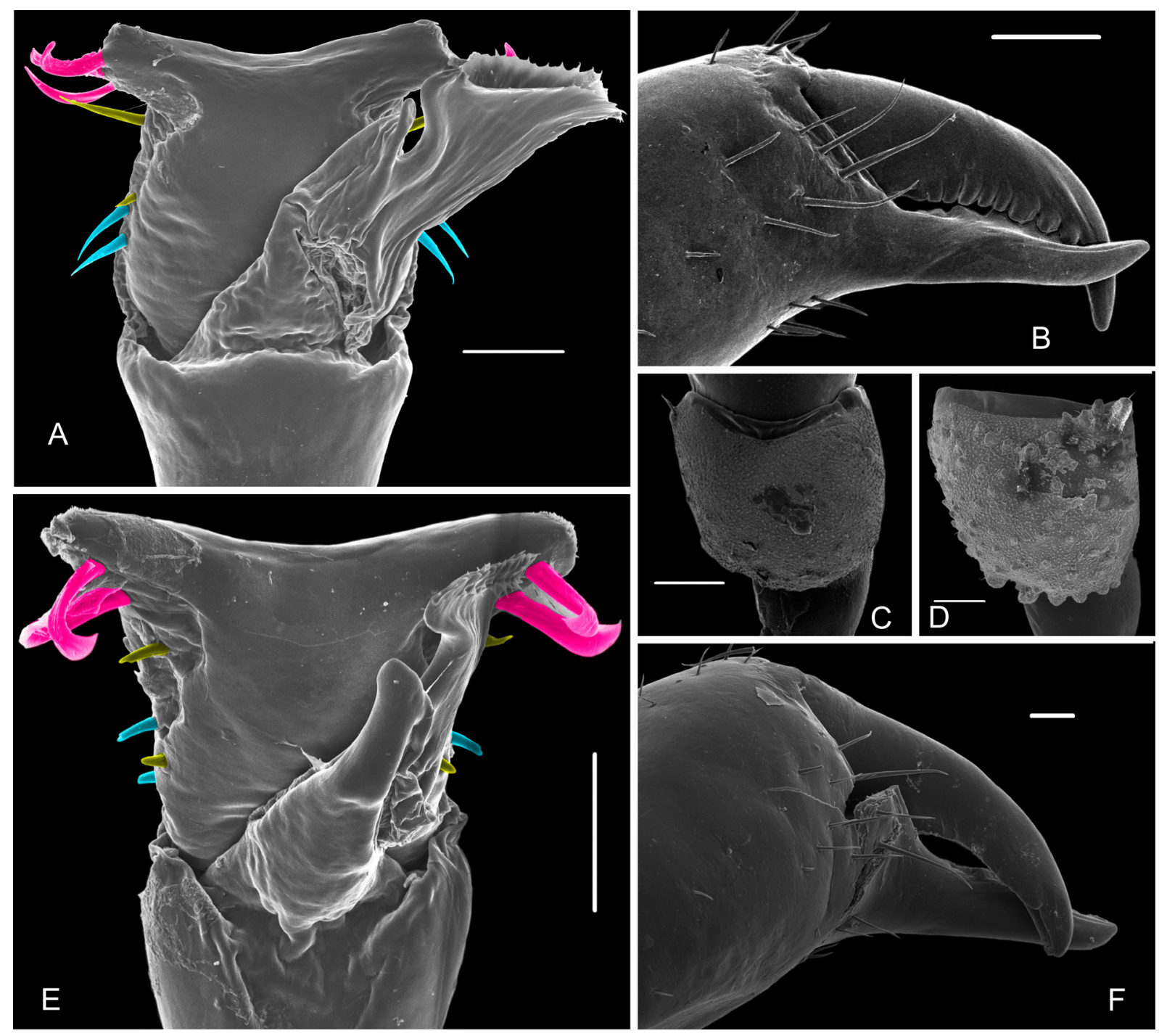

Fig. 4. Structures of presumed related species. - Libitia cordata (Gervais, 1844). A. Distal part of the penis, dorsal view (ICN-AO 413). B. Fingers of the hand of left chelicera (ICN-AO 1040). C. Left basichelicerite, dorsal view (ICN-AO 1040). - Ambatoiella vigilans Mello-Leitão, 1943. D. Left basichelicerite, dorsal view (MNRJ 2524). E. Distal part of the penis, dorsal view (MNRJ 19236). F. Fingers of the hand of left chelicera (MNRJ 2524). Macrosetae colors: fuchsia $=$ MS C, yellow $=$ MS D, aqua blue $=$ MS A. Scale bars: A, E $=50 \mu \mathrm{m} ; \mathrm{F}=100 \mu \mathrm{m} ; \mathrm{B}-\mathrm{D}=200 \mu \mathrm{m}$. 
Chelicerae (Fig. 7F). Basichelicerite uniformly occupied with tubercles of different sizes, some basal and one mesodistal larger; movable finger with row of eleven tubercles, giving a serrated appearance, fixed finger with seven tubercles decreasing in size from basal to distal part of finger.

Pedipalps (Fig. 7D-E). Trochanter with strong ventral process. Femur with pronounced dorsal keel formed by fusion of six tubercles, with ventral row of nine setiferous tubercles and mesodistal process. Patella with mesal keel formed by six small tubercles.

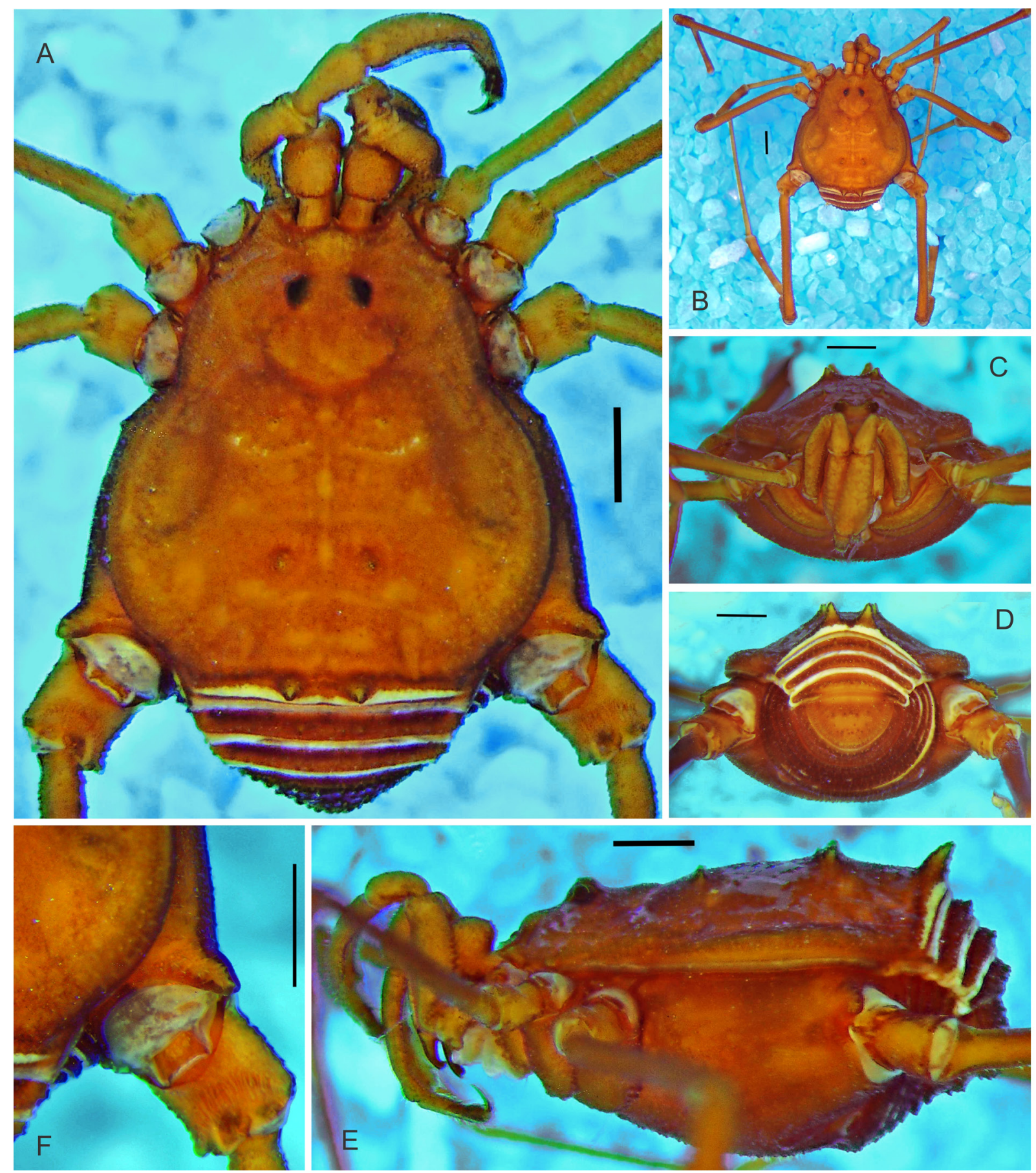

Fig. 5. Eulibitia castor sp. nov., Ô, holotype (ICN-AO 79), habitus. A. Dorsal view. B. Panoramic, dorsal view. C. Frontal view. D. Posterior view. E. Lateral view. F. Detail of apical apophysis of coxa IV. Scale bars: $1 \mathrm{~mm}$. 
LEgs (Fig. 7A-C, G). Coxa IV granulated, with well-marked clavi inguines, distal apophysis of coxa IV slightly tuberculate and directed laterally. Trochanter IV with small retro-distal apophysis. Femur IV straight, with two longitudinal ventral rows of small tubercles along entire length, tubercles increasingly larger distally in prolateral row. Patella IV substraight, with small setiferous tubercles. Tarsal counts: $6(3) / 14(3) / ?-7 / 8$.

Color (Fig. 5). Body and appendages background 48 (Vivid Orange) mottled in 74 (Strong Yellowish Brown), ladder mask 104 (Pale Greenish Yellow). Pedipalpus as well as trochanters and tarsomeres of legs 83 (Brilliant Yellow).

Genitalia (Fig. 6B-C). Penis ventral plate subrectangular, narrower basally and distal border concave; dorsal apophysis of glans rounded, wattle long. Shapes and organization of macrosetae as follows: MS C1-C2 large, curved and flat; MS D1-D2 smaller than MS C and curved at apex; MS A1-A2 large, cylindrical, straight or slightly curved, located in middle of ventral plate; MS B and MS E1-E2 ventral, very small and immersed in microsetae. MS B located at basal fourth of VP.

\section{Female}

Unknown.
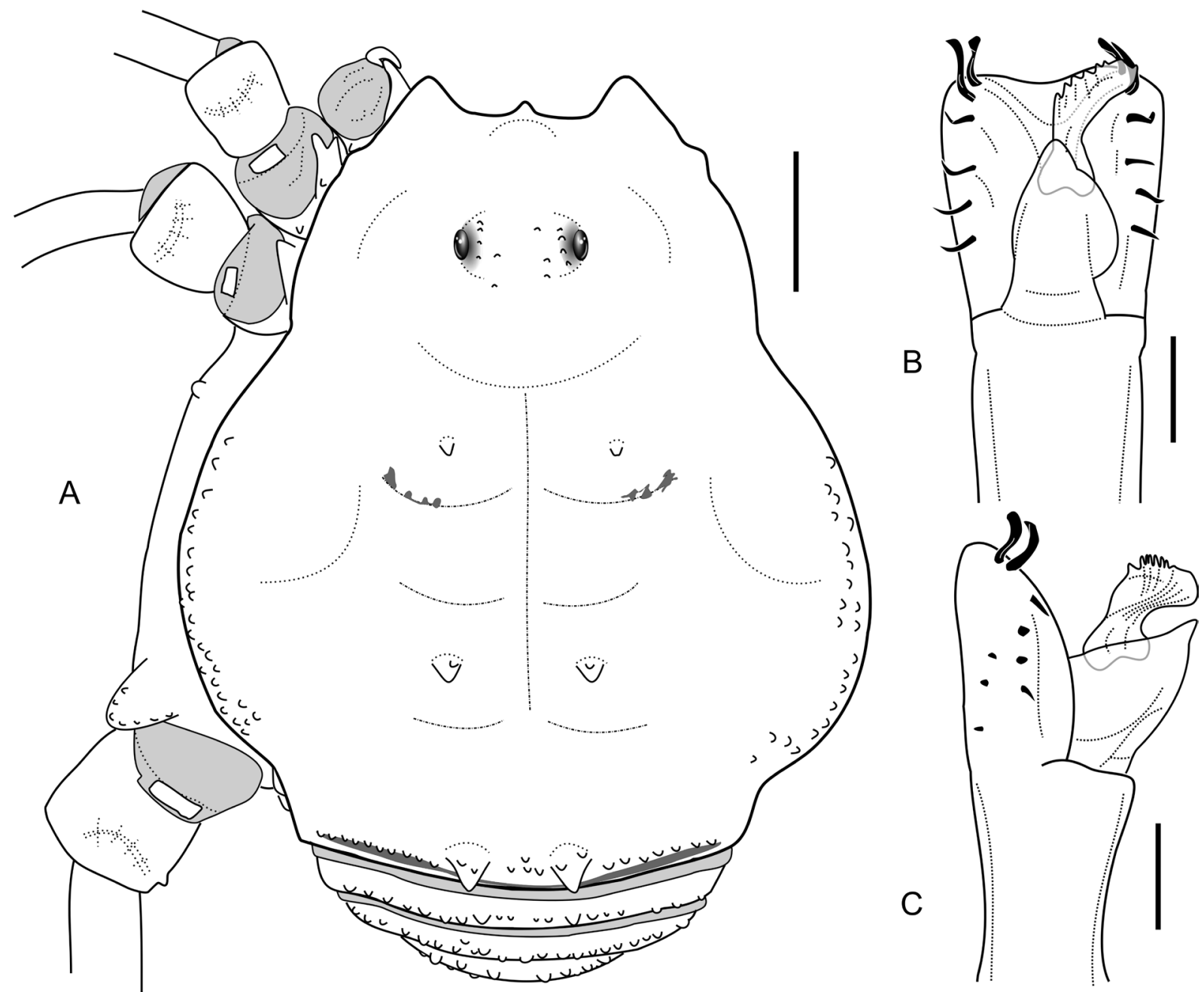

Fig. 6. Eulibitia castor sp. nov., Ô, holotype (ICN-AO 79). A. Habitus, dorsal view. B-C. Apical portion of the penis: B. Dorsal view. C. Lateral view. Scale bars: $A=1 \mathrm{~mm} ; \mathrm{B}-\mathrm{C}=0.1 \mathrm{~mm}$. 


\section{Distribution}

Only known from the type locality, in the WWF ecoregion Cordillera Oriental montane forest (NT0118), tropical and subtropical moist broadleaf forest biome, in Boyacá Department (Fig. 34).

Eulibitia clytemnestra sp. nov.

urn:1sid:zoobank.org:act:3AB34A1C-1F3F-4748-859F-80D4C759152E

Figs $8-10,33$

\section{Diagnosis}

Paramedian tubercles of posterior margin of scutum rounded and contiguous, other areas finely granulated, without tubercles (Fig. 9A). Ladder mask only present in area II, entering only a little into

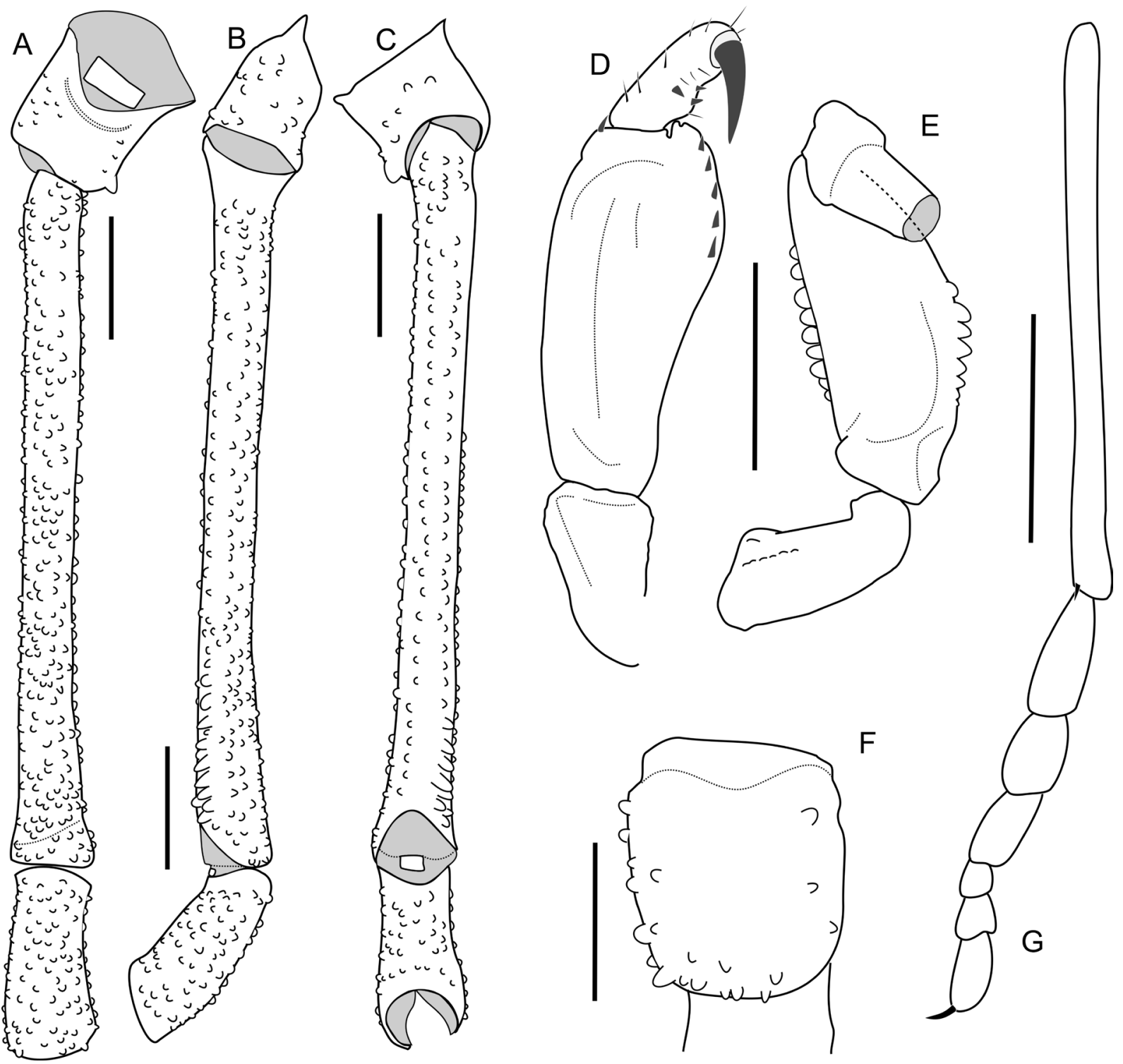

Fig. 7. Eulibitia castor sp. nov., ô, holotype (ICN-AO 79). A. Left femur and trochanter IV, dorsal view. B. Same, prolateral view. C. Same, ventral view. D. Left pedipalpus, tibia and tarsus in ventral view. E. Same, femur and patella in mesal view. F. Left chelicera, dorsal view. G. Left tibia and tarsomeres of leg I, prolateral view. Scale bars: $1 \mathrm{~mm}$. 
scutal grooves (Fig. 8A). Differs from other species of the genus because of the smooth lateral margins (Fig. 9A). Coda very short and mid-bulge asymmetrical, coxa IV slightly granulated, without clavi inguines (Figs 8A, 9A). Femur IV straight, without conspicuous ornamentation (Figs 8D, F, 10A-C).

\section{Etymology}

Noun in apposition from Clytemnestra, daughter of Leda and sister of Helen of Troy, from Greek mythology. Two of the new species of Eulibitia have been named after Helen and Clytemnestra to complete the four siblings originating from the union of Zeus and Leda.
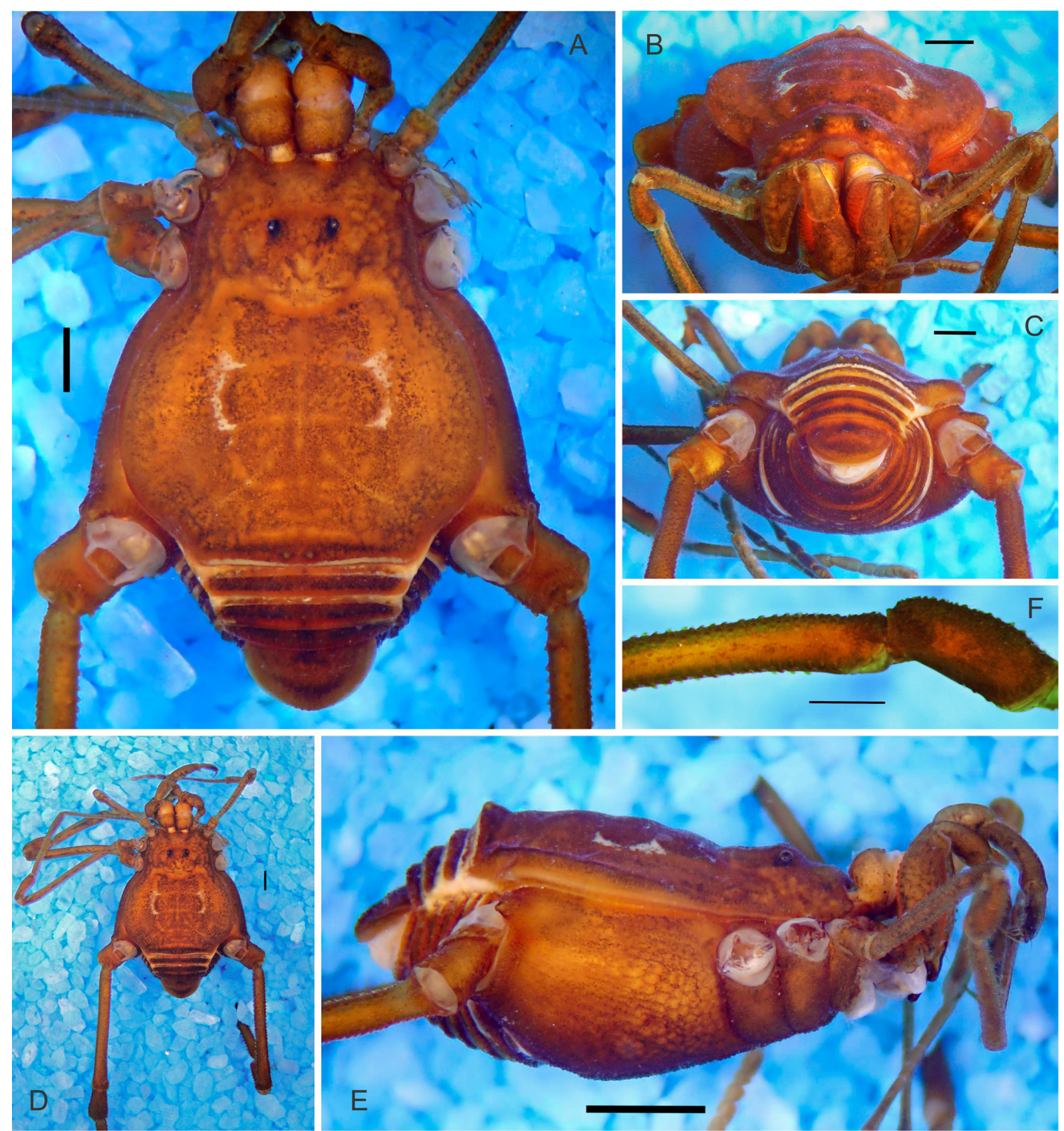

Fig. 8. Eulibitia clytemnestra sp. nov., ð, holotype (ICN-AO 1148), habitus. A. Dorsal view. B. Frontal view. C. Posterior view. D. Panoramic, dorsal view. E. Lateral view. F. Detail of apical distal part of femur IV and trochanter. Scale bars: $1 \mathrm{~mm}$. 


\section{Material examined}

\section{Holotype}

COLOMBIA: đ^, Santander Department, Encino, La Sierra, SFF Guanentá-Alto Río Fonce, $6^{\circ} 0^{\prime} 27.33^{\prime \prime}$ N, $73^{\circ} 08^{\prime} 56.02^{\prime \prime} \mathrm{W}, 2450-2600 \mathrm{~m}$ a.s.1., 10 Jan. 2002, gallery forest, pitfall, S. Arias leg. (ICN-AO 1148).

\section{Description}

\section{Male}

Measurements. $\mathrm{CL}=2.52, \mathrm{AL}=4.29, \mathrm{CW}=3.71, \mathrm{AW}=6.05, \mathrm{Fe} \mathrm{IV}=6.67, \mathrm{Ti} \mathrm{IV}=5.54$.

Dorsum (Figs 8, 9A). Dorsal scutum beta-shaped, with asymmetrical mid-bulge. Posterior margin of scutum with two paramedian rounded tubercles. Lateral margins of scutum smooth. Posterior margin
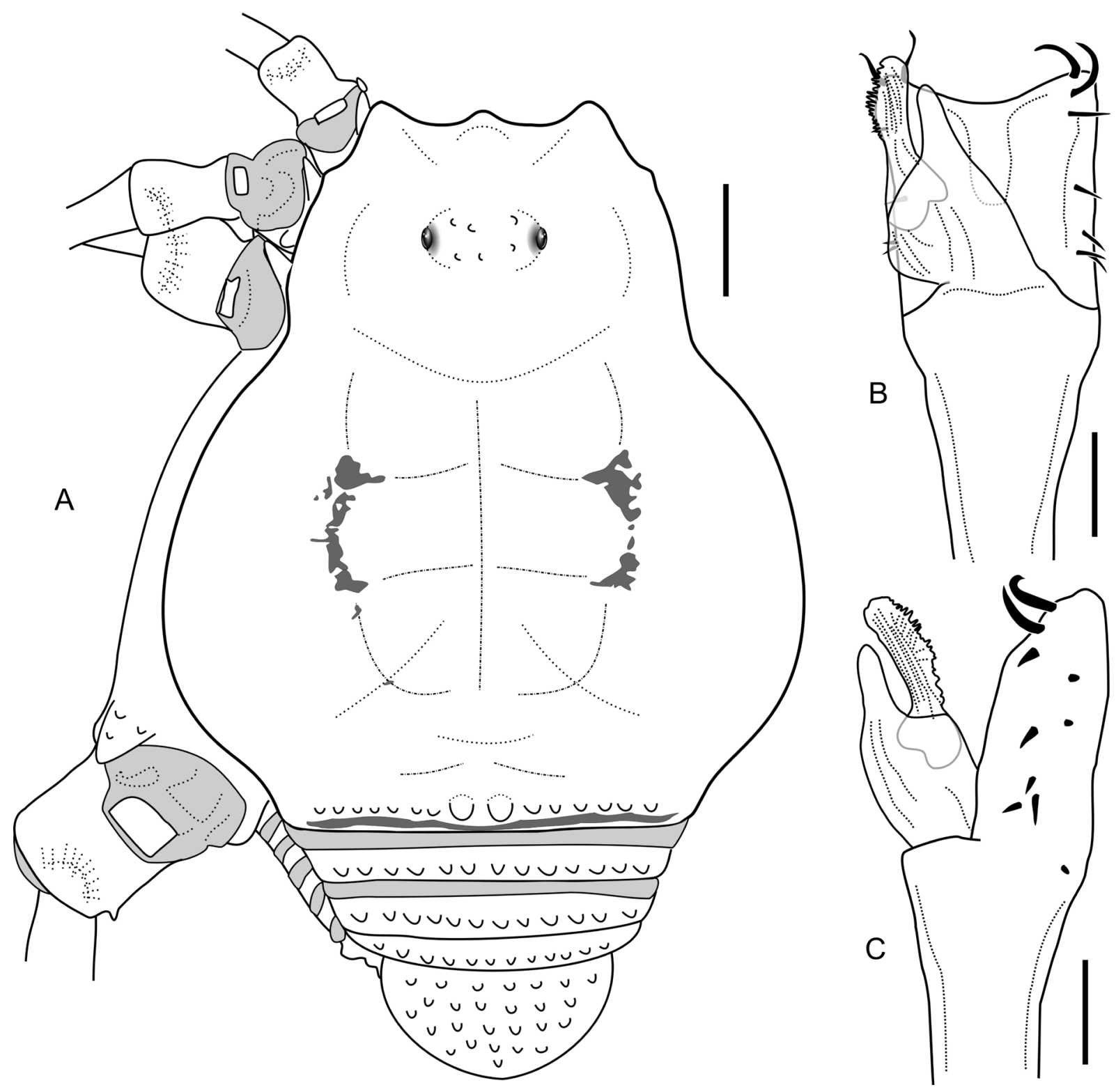

Fig. 9. Eulibitia clytemnestra sp. nov., $\hat{O}$, holotype (ICN-AO 1148). A. Habitus, dorsal view. B-C. Apical portion of penis. B. Dorsal view. C. Lateral view. Scale bars: A $=1 \mathrm{~mm}$; $B-C=0.1 \mathrm{~mm}$. 
of scutum with row of small tubercles. Tergites with row of small tubercles and anal operculum finely granular.

VenTER (Fig. 8C, E). Free sternites finely granular; coxae II-IV finely and uniformly granular; coxa I with longitudinal row of tubercles and smooth area corresponding to locking area of Pp Tr.

Chelicerae (Fig. 10F). Basichelicerite with minute tubercles on ecto-basal side and two on antero-mesal corner; movable finger with row of tubercles, giving a serrated appearance, and large basal tubercle; fixed finger with five tubercles decreasing in size from basal to distal part of finger.

Pedipalps (Fig. 10D-E). Trochanter with strong ventral process. Femur with pronounced dorsal row of seven tubercles, with ventral row of ten setiferous tubercles and mesodistal process. Patella with low mesal keel.

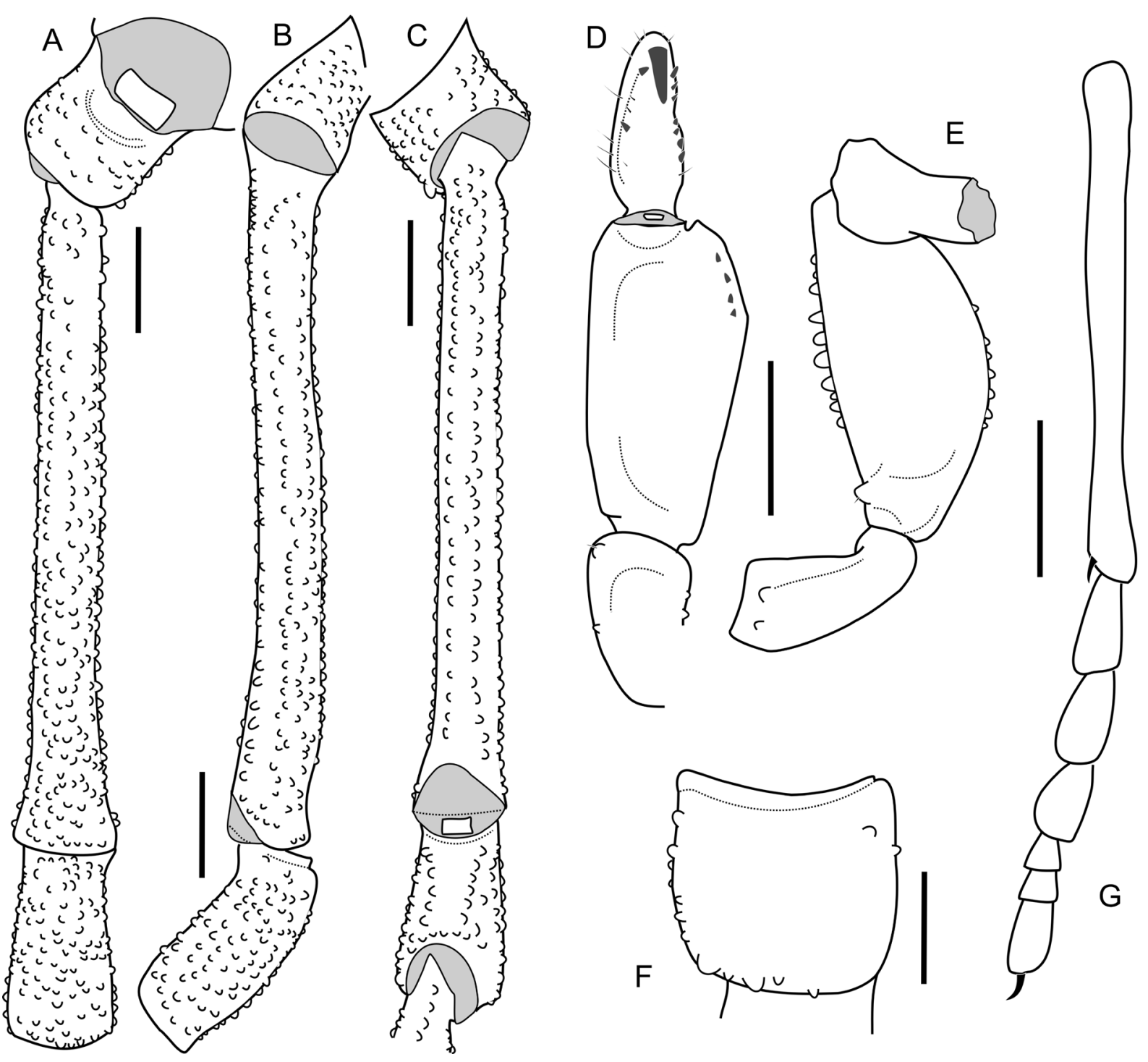

Fig. 10. Eulibitia clytemnestra sp. nov., Ô, holotype (ICN-AO 1148). A. Left femur and trochanter IV, dorsal view. B. Same, prolateral view. C. Same, ventral view. D. Left pedipalpus, tibia and tarsus in ventral view. E. Same, femur and patella in mesal view. F. Left chelicera, dorsal view. G. Left tibia and tarsomeres of leg I, prolateral view. Scale bars: $1 \mathrm{~mm}$. 
LEGs (Figs 8F, 10A-C, G). Coxa IV finely granulated, without clavi inguines, distal apophysis of coxa IV slightly tuberculate and directed laterally. Trochanter IV with small retro-distal apophysis. Femur IV straight, with two longitudinal ventral rows of small tubercles along entire length. Patella IV substraight, with small tubercles. Tarsal counts: 6(3)/12-11(3)/7-?/8.

Color (Fig. 8). Body and appendages color background 68 (Strong Orange Yellow), ladder mask 104 (Pale Greenish Yellow). Trochanter and tarsomeres 98 (Brilliant Greenish Yellow).

Genitalia (Fig. 9B-C). Ventral plate subrectangular, narrower basally and distal border hardly concave; dorsal apophysis of glans long and rounded, wattle long. Shapes and organization of macrosetae as follows: MS C1-C2 large, curved and flat; MS D1-D2 large and straight, D2 smaller than D1 and located closer to MS A1; MS A1-A2 large, cylindrical, straight, located in basal middle of ventral plate (asymmetry in number of MS A already seen in E. maculata); MS B and MS E1-E2 ventral, very small and immersed in microsetae. Pair of MS B at base of ventral plate.

\section{Female}

Unknown.

\section{Distribution}

Only known from the type locality, in the WWF ecoregion Magdalena Valley montane forests (NT0136), tropical and subtropical moist broadleaf forest biome, in Santander Department (Fig. 33).

Eulibitia ectroxantha (Mello-Leitão, 1941) comb. nov., species inquirenda

Fig. 34

Brachylibitia ectroxantha Mello-Leitão, 1941: 166, fig 1.

Cynorta ectroxantha - Goodnight \& Goodnight 1953: 38.

Brachylibitia ectroxantha - Kury 2003: 38.

Platymessa ectroxantha - Medrano \& Kury 2016: 57 (tagged as species inquirenda).

\section{Diagnosis}

Paramedian tubercles of posterior margin of scutum acuminate. Differs from other species of the genus in the presence of paramedian tubercles in area III but without any armature in area I, and the ladder mask with rungs only, no rails in scutal grooves I, II and III (see Mello-Leitão 1941 and Medrano \& Kury 2016).

\section{Etymology}

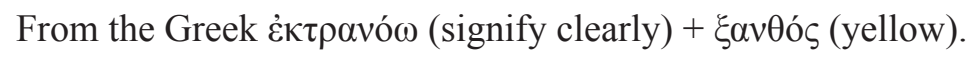

\section{Type data}

Whereabouts of type(s) unknown, probably once deposited in MNRJ, now lost. Type locality: Colombia, Boyacá Department, La Uvita $\left[06^{\circ} 17^{\prime} \mathrm{N}, 72^{\circ} 30^{\prime} \mathrm{W}\right]$.

\section{Remarks}

This species was discussed and tagged as species inquirenda in Medrano \& Kury (2016) and the available information is sufficient to include it within the new diagnosis of Eulibitia. 
Eulibitia h-inscriptum (Mello-Leitão, 1941) comb. nov.

Fig. 32

Platymessa h-inscripta Mello-Leitão, 1941: 167, fig 2.

Platymessa nigrolimbata Mello-Leitão, 1941: 168, fig 3 (junior subjective synonym of Platymessa h-inscripta according to Medrano \& Kury 2016).

Platymessa nigrolimbata - B. Soares 1945: 344. - Kury 2003: 81.

Cynorta h-inscripta - H. Soares 1970: 325.

Platymessa h-inscripta - Kury 2003: 81.

Platymessa h-inscriptum - Kury \& Alonso-Zarazaga 2011: 51. — Medrano \& Kury 2016: 58, figs 1-29.

\section{Diagnosis}

E. h-inscriptum has a pair of paramedian tubercles in areas I, III and on the posterior margin, but differs from its congenerics because its ladder mask is not confined to the mesotergum, reaching the lateral margins of the scutum.

\section{Material examined}

\section{Holotypes}

COLOMBIA: $\widehat{\jmath}$, Santander Department, Espinal (holotype of Platymessa h-inscripta, MNRJ 282).

COLOMBIA: , , Santander Department, San Gil (holotype of Platymessa nigrolimbata, MNRJ 463).

Paratypes

COLOMBIA: $2 \widehat{\jmath}, 1$ + , Boyacá Province, La Uvita (paratypes of Platymessa nigrolimbata, MNRJ $58)$.

\section{Other material}

COLOMBIA: 1 ô, 11 우, Boyacá Department, Tipacoque, Vereda La Calera, 6 $23.8^{\prime} 91^{\prime \prime} \mathrm{N}$, $72^{\circ} 43.4^{\prime} 10^{\prime \prime}$ W, 2800 m a.s.1., 1-5 Apr. 2013, M. Medrano leg. (ICN-AO 1186); 1 ㄱ, 2 우우, Santander Province, Zapatoca, Vereda La Cacica, Reserva La Montaña Mágica, 650.044' N, 73¹8.241' W, 1964 m a.s.1., 6 Nov. 2013, C. Perafán and D. Martínez leg. (ICN-AO 1384).

\section{Remarks}

This species was recently redescribed by Medrano \& Kury (2016) and their morphological features match the new diagnosis of Eulibitia.

Eulibitia helena sp. nov. urn:Isid:zoobank.org:act:24196992-FBD8-405D-8F75-DFCF7F811D97

Figs 11-14, 34; Table 1

\section{Diagnosis}

Paramedian rounded tubercles in areas I, III and posterior margin of scutum, other areas finely granulated, without tubercles (Fig. 12A). Coda short and mid-bulge slightly asymmetrical (Fig. 12A), coxa IV finely granulated, with well-marked clavi inguines (Fig. 12A). Differs from other species of the genus because the ladder mask rails and rungs overflow the scutal grooves to reach areas I, II and III (Fig. 11A), and beacuse femur IV is straight in dorsal view, with a large dorso-apical spine (Figs 11B, 12C-E). 


\section{Etymology}

Noun in apposition for Helen of Troy, daughter of Leda and cause of the Trojan War in Greek mythology.

\section{Material examined}

\section{Holotype}

COLOMBIA: $\widehat{\jmath}$, Norte de Santander Department, Cucutilla, Vereda Carrizal, Sector Sisavita, Quebrada Poveda [7.406 $\mathrm{N}, 72.836^{\circ} \mathrm{W}, 2040 \mathrm{~m}$ a.s.l. $(\mathrm{IAvH} 45)$.

\section{Paratypes}

COLOMBIA: $1 \hat{\jmath}$, same collection data as for holotype (IAvH 38); 3 q $q$, same collection data as for holotype (IAvH 25, IAvH 32, IAvH 51); 1 q, Santander Department, Suaita, San José de Suaita, Bosque
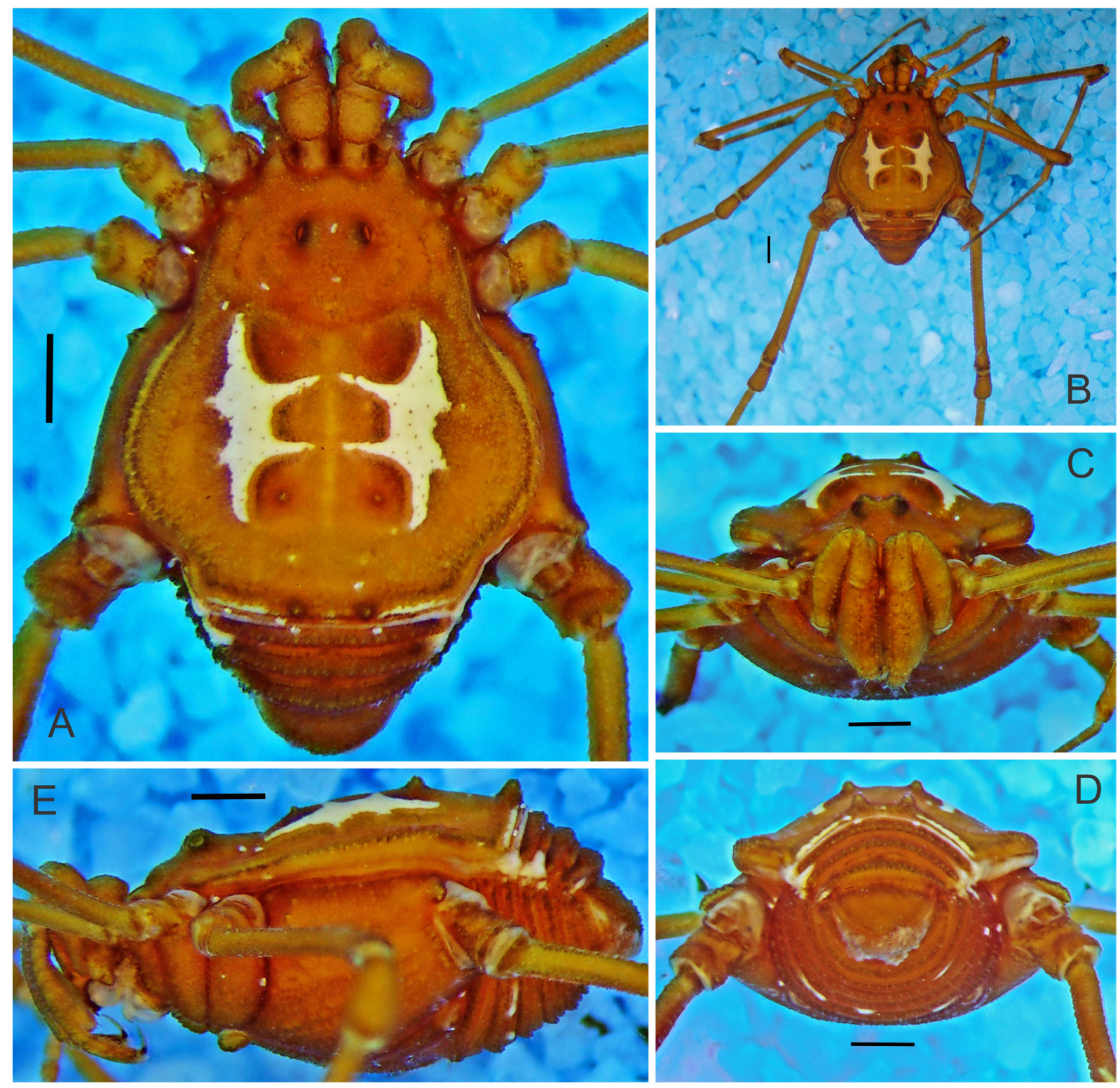

Fig. 11. Eulibitia helena sp. nov., $\widehat{\jmath}$, holotype (IAvH 45), habitus. A. Dorsal view. B. Panoramic, dorsal view. C. Frontal view. D. Posterior view. E. Left lateral view. Scale bars: $1 \mathrm{~mm}$. 


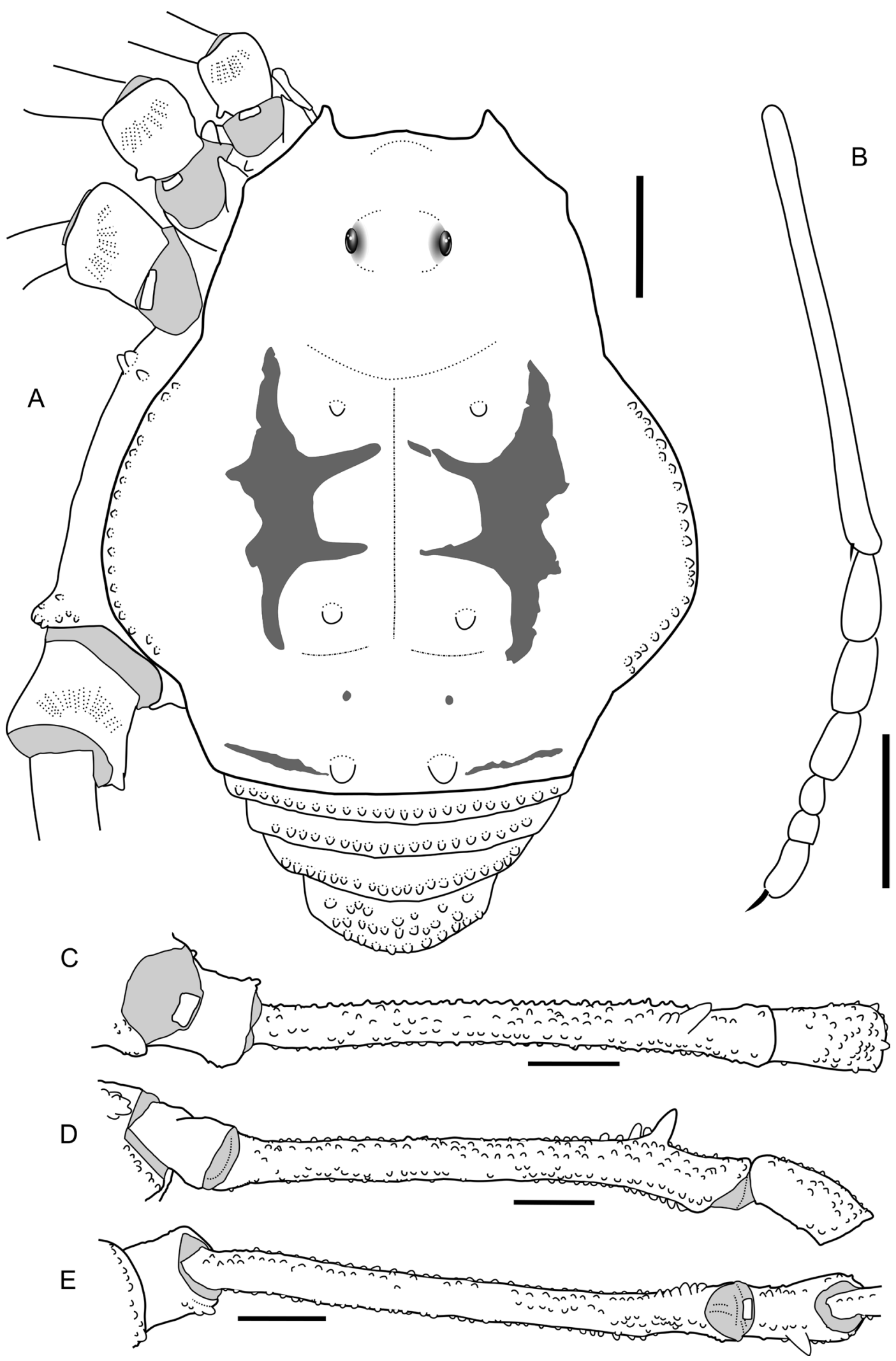

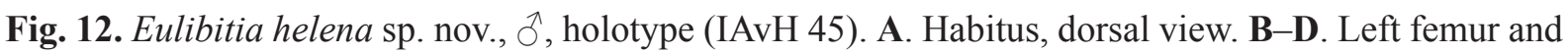
trochanter. B. Dorsal view. C. Prolateral view. D. Ventral view. E. Left metatarsus and tarsomeres of leg I, prolateral view. Scale bars: $1 \mathrm{~mm}$. 
de la Fundación San Cipriano [6.167 N, 73.423 W], 1780 m a.s.1., 3 Jul. 2014, Jameo, C. Romero and D. Martínez leg. (ICN-AO 1429).

\section{Description}

Male (based on holotype)

Measurements. $\mathrm{CL}=1.70, \mathrm{AL}=3.59, \mathrm{CW}=3.01, \mathrm{AW}=4.81, \mathrm{Fe} \mathrm{IV}=6.08, \mathrm{Ti} \mathrm{IV}=3.90$.

Dorsum (Figs 11, 12A). Dorsal scutum beta-shaped, with slightly asymmetrical mid-bulge. Areas I, III and posterior margin with two paramedian rounded tubercles. Lateral margins of scutum irregularly granulate. Posterior margin of scutum with row of small tubercles. Tergites with row of small tubercles and anal operculum finely granular.
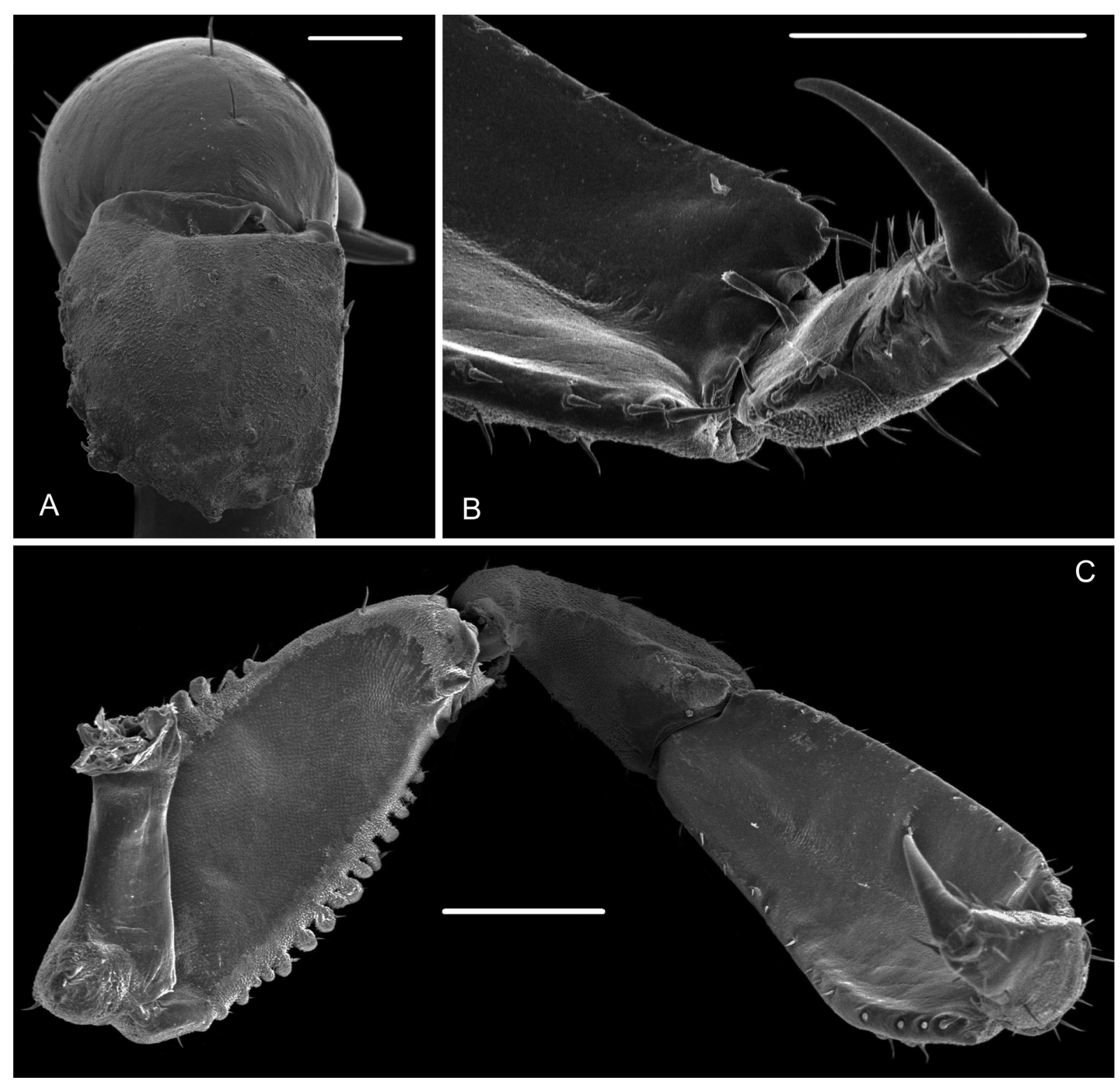

Fig. 13. Eulibitia helena sp. nov., đ̂, paratype (IAvH 38). A. Left chelicera, dorsal view. B. Detail of tarsus and tarsal claw of left pedipalpus, ventro-apical view. C. Left pedipalpus, mesal view. Scale bars: $\mathrm{A}=200 \mu \mathrm{m} ; \mathrm{B}-\mathrm{C}=500 \mu \mathrm{m}$. 
VeNTER (Fig. 11C-E). Free sternites finely granular; coxae II-IV finely and uniformly granular; coxa I with longitudinal row of tubercles and smooth area corresponding to lace area of pedipalp.

Chelicerae (Fig. 13A). Basichelicerite with small tubercles on dorsal surface and some larger ones on ecto-basal side, movable finger with row of ten small tubercles, giving a serrated appearance; fixed finger with five tubercles, decreasing in size from basal to distal part of finger.

Pedipalps (Fig. 13B-C). Trochanter with strong ventral process. Femur with pronounced dorsal row of seven tubercles, with ventral row of fifteen setiferous tubercles and mesodistal process. Patella with low mesal keel ending in setiferous tubercle.

LEgs (Fig. 12B-E). Coxa IV finely granulated, with clavi inguines, distal apophysis of coxa IV slightly tuberculate and directed laterally. Trochanter IV with small retro-distal apophysis. Femur IV straight, with two longitudinal ventral rows of small tubercles along entire length, dorsal row of tubercles increasing in size, with large apical spine. Patella IV substraight, with small tubercles. Tarsal counts: $6(3) / 14-?(3) / 7 / 8$.

Color (Fig. 11). Body color background 49 (Brilliant Orange), ladder mask 104 (Pale Greenish Yellow). Appendages 67 (Brilliant Orange Yellow).

Genitalia (Fig. 14). Ventral plate subrectangular, narrower basally and distal border substraight, dorsoapical membranous invaginations basal to MSC; dorsal apophysis of glans long and rounded, wattle long. Shapes and organization of macrosetae as follows: MS C1-C2 large, curved and flat; MS D1-D2 large and straight, D2 smaller than D1 and located closer to MS A1; MS A1-A2 large, cylindrical, straight, located on basal middle of ventral plate; MS B and MS E1-E2 ventral, very small and immersed in microsetae. Pair of MS B at base of ventral plate.

\section{Variation}

There is a limited sample of blots $(\mathrm{n}=7)$, the parallel bars (rails) may be more or less wide and the posterior stripe is sometimes interrupted by the paramedian tubercles (Figs 11A, 12A). The dorso-distal tubercle of Fe IV may seem bifurcate by the growth of the tubercles of its own base. Tarsal counts: 5-6; $8-12 ; 5-6 ; 6-7$. Variation of measurements is given in Table 1.
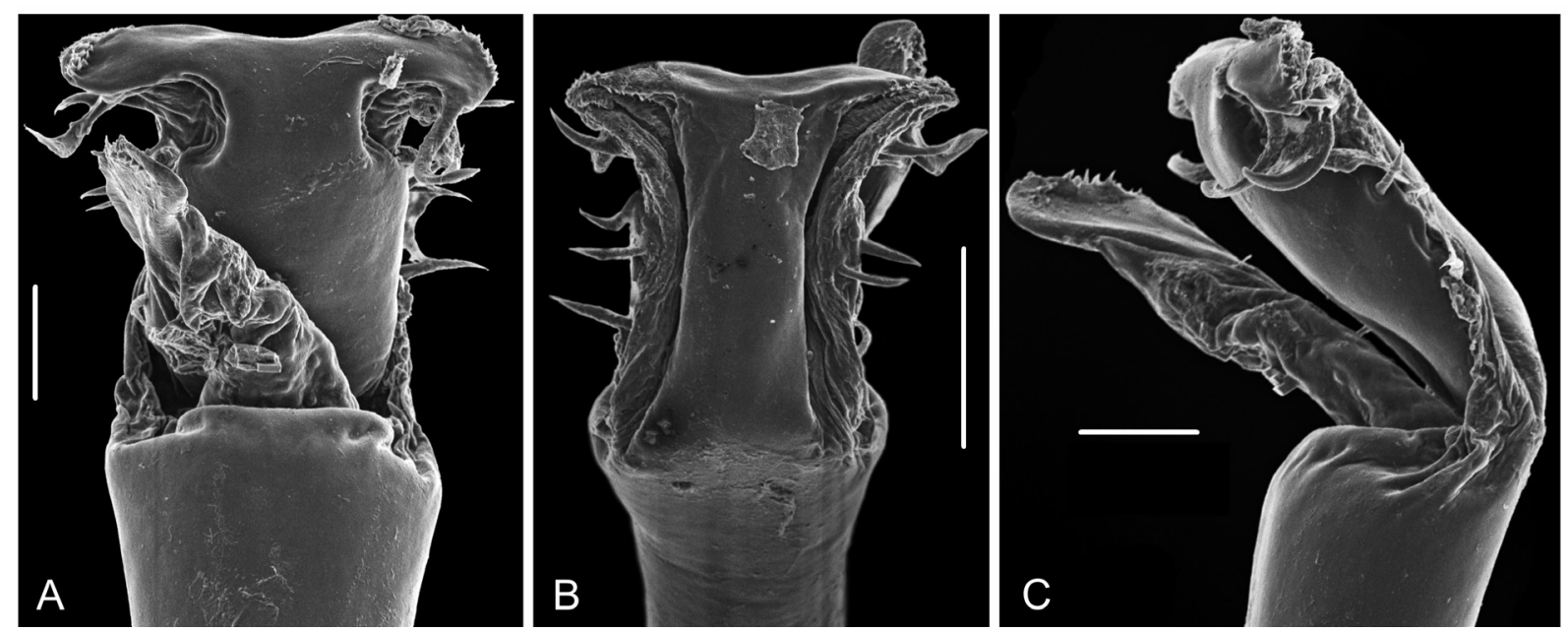

Fig. 14. Eulibitia helena sp. nov., $\hat{0}$, paratype (IAvH 38). A. Distal view of penis, dorsal view. B. Same, ventral view. C. Same, lateral view. Scale bars: A, C $=50 \mu \mathrm{m}$; B $=100 \mu \mathrm{m}$. 
Table 1. Measurements of body and appendages of Eulibitia helena sp. nov.

\begin{tabular}{|c|c|c|c|c|}
\hline & IAvH 25 (†) & ICN-AO 1429 ( $\left.{ }^{\circ}\right)$ & IAvH $45\left({ }^{\text {丸) }}\right.$ & IAvH 38 (す) \\
\hline$\overline{\mathrm{CL}}$ & 1.57 & 1.56 & 1.70 & 2.02 \\
\hline $\mathrm{AL}$ & 3.48 & 3.19 & 3.59 & 3.57 \\
\hline $\mathrm{CW}$ & 2.97 & 2.73 & 3.01 & 3.12 \\
\hline AW & 4.61 & 4.49 & 4.81 & 4.85 \\
\hline Fe I & 2.61 & 3.45 & 2.98 & 3.23 \\
\hline Ti I & 1.91 & 2.07 & 1.97 & 2.02 \\
\hline Fe II & 5.31 & 7.50 & 5.85 & 6.26 \\
\hline Ti II & 4.18 & 5.67 & 4.54 & 4.64 \\
\hline Fe III & 4.27 & 5.15 & 4.65 & 4.92 \\
\hline Ti III & 2.43 & 2.13 & 2.70 & 2.71 \\
\hline Fe IV & 5.42 & 6.55 & 6.08 & 6.40 \\
\hline Ti IV & 3.55 & 4.04 & 3.90 & 4.08 \\
\hline
\end{tabular}

\section{Female}

Clavi inguines larger than in male. Basitarsomeres in legs I thickened but not swollen (Fig. 12B).

\section{Distribution}

E. helena sp. nov. occurs in two WWF ecoregions: (1) Magdalena Valley montane forests (NT0136), tropical and subtropical moist broadleaf forest biome, in Santander Department, and (2) Cordillera Oriental montane forest (NT0118), tropical and subtropical moist broadleaf forest biome, in Norte de Santander Department (Fig. 34).

\section{Eulibitia leda sp. nov. urn:1sid:zoobank.org:act:C2EE6C34-F8EE-4327-B88B-4565A06D09FE}

Figs 15-18, 33; Table 2

\section{Diagnosis}

Paramedian rounded tubercles widely separated in areas I, III and IV (Figs 15, 16A). Ectal borders of protoglyphs conspicuous, triangular and sharp (Figs 15A, 16A). Coda short and wide (Fig. 15A). Clavi inguines large (Fig. 15A), basichelicerite with large tubercles in the basal part (Fig. 17B). Pedipalpal femur wider at half length (Fig 17E).

This species is very similar to E. scalaris in the shape of the ladder mask, but differs by having a short coda with the constriction poorly marked (Fig. 15A), the basichelicerite bears larger tubercles (Figs 15A, 17B) and the femur of leg IV is more tuberculated in the ventro-distal region (Fig. 17G-H, J). Apophyses of coxa IV acuminate and poorly tuberculated (Figs 15, 16A).

\section{Etymology}

Noun in apposition of Leda, mother of Clytemnestra, Castor, Pollux and Helen of Troy, from Greek mythology. This species has been named Leda to round up the family formed from the union of Zeus and Leda. 


\section{Material examined}

\section{Holotype}

COLOMBIA: ${ }^{\lambda}$, Santander Department, San Gil, Vereda Resumidero, road to Mogotes, $6^{\circ} 32^{\prime} 28.25^{\prime \prime} \mathrm{N}$, 7305'28.75" W, 1600 m a.s.1., 30 Mar. 2013, A. García leg. (ICN-AO 1165).

\section{Paratypes}

COLOMBIA: $5 \widehat{\partial}, 5$ $q$, , same collection data as for holotype (ICN-AO 1165.1); $1 \hat{\jmath}, 1$, same collection data as for holotype (MNRJ 9264).

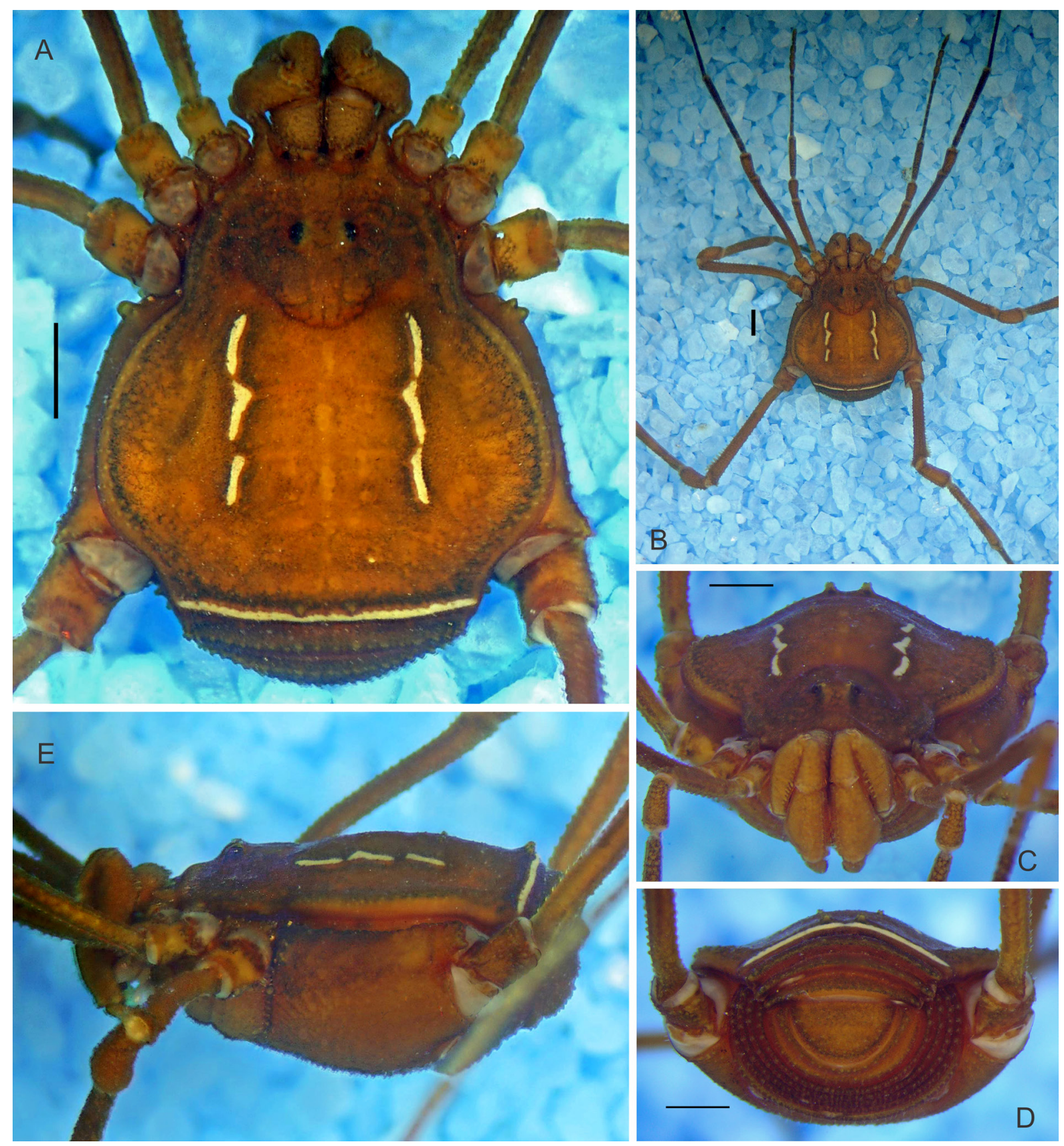

Fig. 15. Eulibitia leda sp. nov., ${ }^{\lambda}$, holotype (ICN-AO 1165), habitus. A. Dorsal view. B. Panoramic, dorsal view. C. Frontal view. D. Posterior view. E. Lateral view. Scale bars: $1 \mathrm{~mm}$. 


\section{Description}

Male (based on holotype)

Measurements. $\mathrm{CL}=2.11, \mathrm{AL}=3.29, \mathrm{CW}=3.11, \mathrm{AW}=5.08, \mathrm{Fe} \mathrm{IV}=5.19$, $\mathrm{Ti} \mathrm{IV}=3.41$.

Dorsum (Figs 15, 16A). Dorsal scutum beta-shaped, with asymmetrical mid-bulge. Areas I, III and posterior margin with two paramedian tubercles, tubercles of posterior margin bifid. Lateral margins with irregular row of minute granules at mid-bulge. Posterior margin of scutum with row of small tubercles. Tergites with row of small tubercles and anal operculum finely granular.

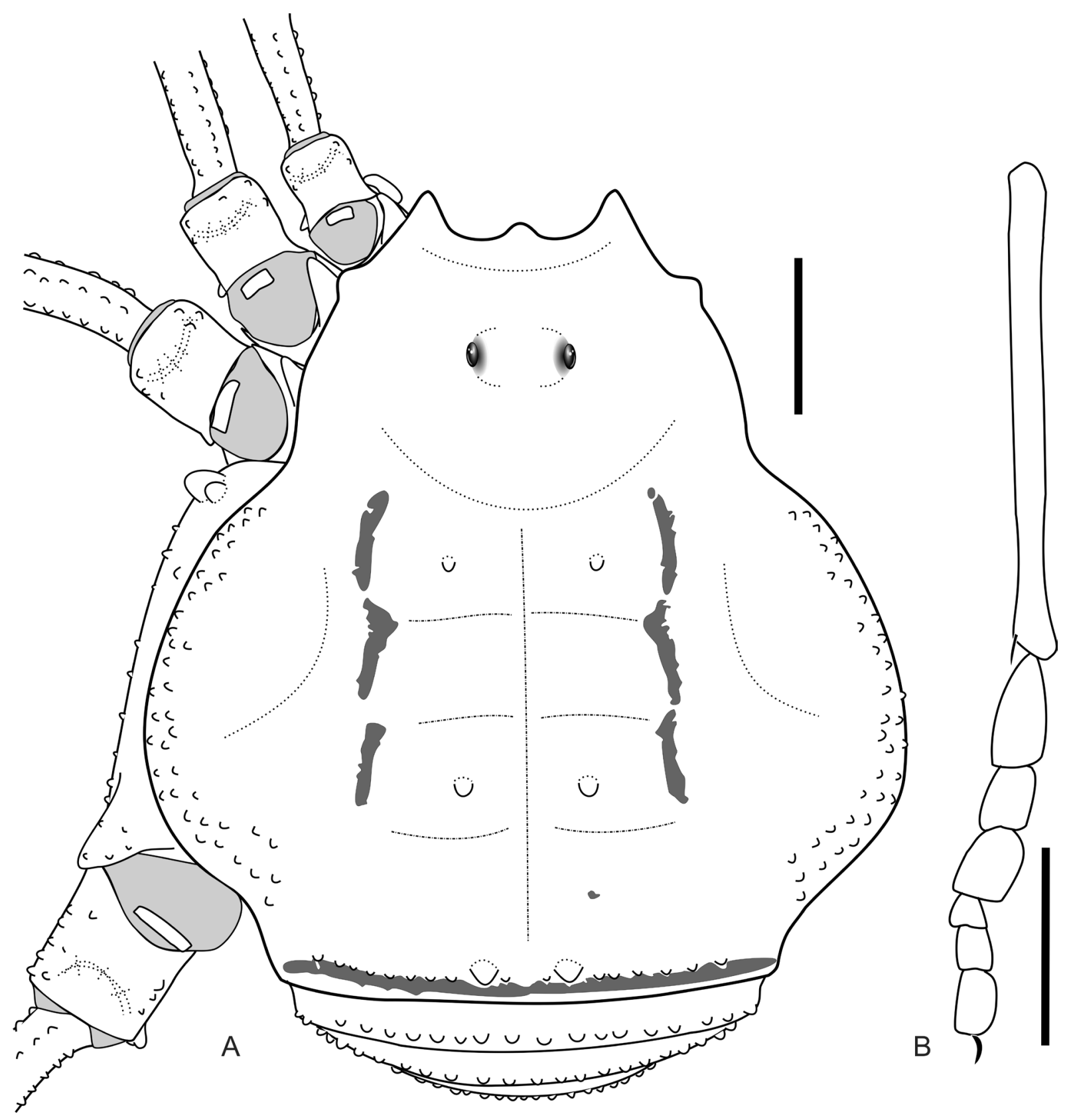

Fig. 16. Eulibitia leda sp. nov., Ô, holotype (ICN-AO 1165). A. Habitus in dorsal view. B. Left Mt and Ta of leg I, prolateral view. Scale bar: $1 \mathrm{~mm}$. 
Venter (Fig. 15D-E). Free sternites finely granular; coxae II-IV finely and uniformly granular; coxa I with longitudinal row of tubercles and smooth area corresponding to lace area of pedipalp.
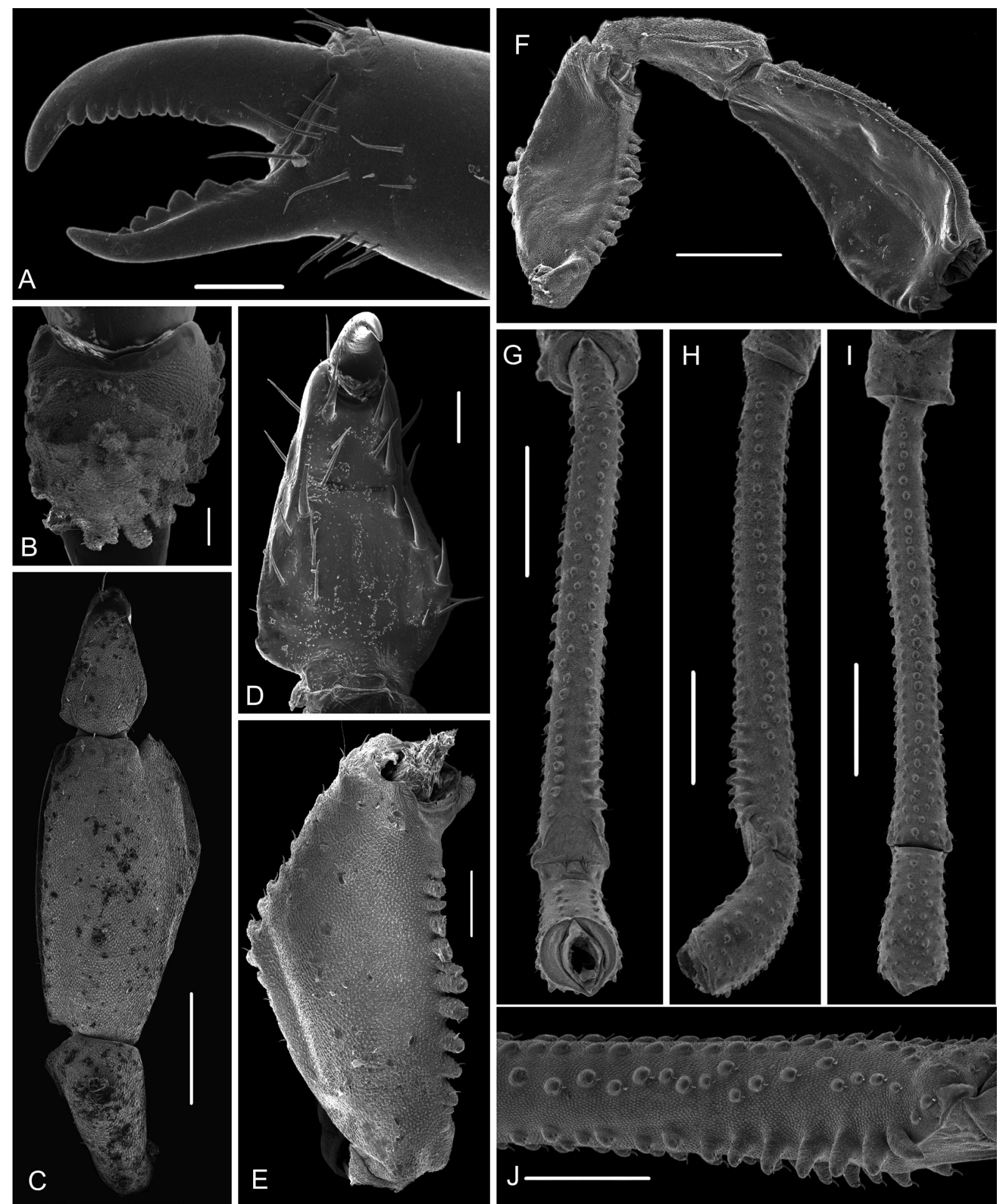

Fig. 17. Eulibitia leda sp. nov., ô, paratype (ICN-AO 1165.1). A. Fingers of hand of right chelicera. B. Right basichelicerite, dorsal view. C. Patella and tibia of right pedipalpus, dorsal view. D. Left pedipalpal tarsus. E. Femur of right pedipalpus, ectal view. F. Left pedipalpus, mesal view. G. Femur and patella of left leg, ventral view. H. Same, prolateral view. I. Same, dorsal view. J. Same, detail of distal part, prolateral view. Scale bars: A-B, D =100 $\mu \mathrm{m} ; \mathrm{C}, \mathrm{F}, \mathrm{J}=500 \mu \mathrm{m} ; \mathrm{E}=200 \mu \mathrm{m}(\mathrm{E}) ; \mathrm{G}-\mathrm{I}=1 \mathrm{~mm}$. 
Chelicerae (Fig. 17A-B). Basichelicerite with row of large tubercles from posterior border to ectal side; movable finger with row of ten tubercles, fixed finger with two small basal tubercles and five large tubercles decreasing in size from basal to distal part of finger.

Pedipalps (Fig. 17C-F). Trochanter with strong ventral process. Femur with pronounced dorsal keel formed by row of tubercles, with ventral row of twelve setiferous tubercles and mesodistal process. Patella with mesal keel without tubercles but with distal process. Shallow slit along tibia mesal surface, separating dorsal and ventral sides.

Legs (Figs 16B, 17G-J). Coxa IV granulated, with large clavi inguines, larger in females. Trochanter IV with small retro-distal apophysis. Femur IV substraight, with two longitudinal ventral rows of tubercles increasing in size in distal part. Patella IV substraight, with small setiferous tubercles. Tarsal counts: 6-6/11-10/6-6/7-7.

Color (Fig. 15). Body and appendages color background 51 (Deep Orange) mottled in 44 (Dark Reddish Brown), ladder mask 104 (Pale Greenish Yellow). Trochanters and tarsomeres 67 (Brilliant Orange Yellow).

Genitalia (Fig. 18). VP of penis subrectangular, narrower basally, with distal border concave; dorsal apophysis of glans subsquare to rounded, wattle of stylus long. Shapes and organization of macrosetae as follows: MS C1-C2 large, curved and flattened; MS D1-D2 large and straight; MS A1-A2 large, straight, cylindrical and located in basal middle of ventral plate; MS B and MS E1-E2 ventral, very small and immersed in microsetae. MS B most basal. Microsetae confined to lateral margins, from corners to base, of VP.

\section{Variation}

Right tubercle of the posterior margin may be absent in some specimens. Tarsal counts: $6 ; 10-13 ; 6-7$; $7-8$. Variation of measurements is given in Table 2.
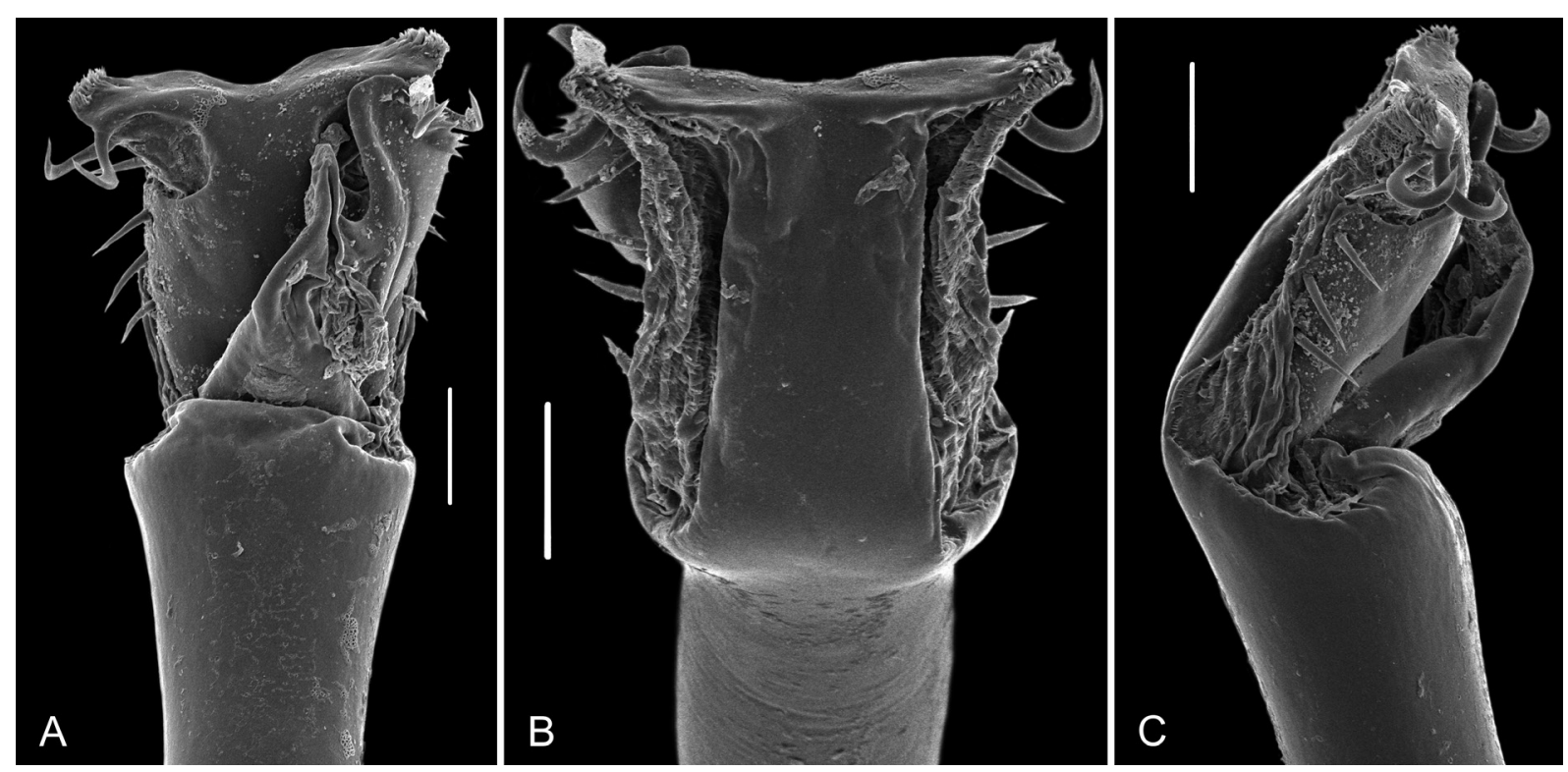

Fig. 18. Eulibitia leda sp. nov., Ô, paratype (ICN-AO 1165.1), distal part of penis. A. Dorsal view. B. Ventral view. C. Lateral view. Scale bars: $50 \mu \mathrm{m}$. 
Table 2. Measurements of body and appendages of Eulibitia leda sp. nov.

\begin{tabular}{|c|c|c|c|c|c|c|c|}
\hline & $\begin{array}{c}\text { ICN-AO } 1165 \\
\left(\bigotimes^{3}\right)\end{array}$ & $\begin{array}{c}\text { MNRJ } 9264 \\
\left(\begin{array}{l}1 \\
0\end{array}\right)\end{array}$ & $\begin{array}{l}\text { MNRJ } 9264 \\
\text { (P) }\end{array}$ & $\begin{array}{c}\text { ICN-AO } 1165.1 \\
\left(\begin{array}{c}1 \\
\text { I }\end{array}\right.\end{array}$ & $\begin{array}{c}\text { ICN-AO } 1165.1 \\
\left(O^{1}\right)\end{array}$ & $\begin{array}{c}\text { ICN-AO } 1165.1 \\
(+)\end{array}$ & $\begin{array}{c}\text { ICN-AO } 1165.1 \\
\text { (ํ) }\end{array}$ \\
\hline $\mathrm{CL}$ & 2.11 & 1.96 & 1.65 & 1.81 & 1.54 & 1.70 & 1.73 \\
\hline $\mathrm{AL}$ & 3.29 & 3.23 & 3.26 & 3.30 & 2.62 & 3.35 & 3.30 \\
\hline $\mathrm{CW}$ & 3.11 & 2.94 & 2.76 & 2.99 & 2.44 & 2.88 & 2.82 \\
\hline AW & 5.08 & 4.89 & 4.62 & 4.64 & 3.89 & 4.72 & 4.40 \\
\hline $\mathrm{Fe} \mathrm{I}$ & 2.52 & 2.75 & 2.26 & 2.46 & 2.36 & 2.40 & 2.28 \\
\hline Ti I & 1.89 & 2.00 & 1.65 & 1.89 & 1.61 & 1.60 & 1.69 \\
\hline $\mathrm{Fe}$ II & 4.88 & 5.44 & 4.29 & 4.98 & 4.38 & 4.80 & 4.66 \\
\hline Ti II & 3.99 & 4.22 & 3.28 & 3.84 & 3.59 & 3.71 & 3.61 \\
\hline Fe III & 3.78 & 4.06 & 3.43 & 3.61 & 3.36 & 3.53 & 3.53 \\
\hline Ti III & 2.24 & 2.50 & 2.04 & 2.34 & 1.97 & 2.33 & 2.19 \\
\hline Fe IV & 5.19 & 5.09 & 4.21 & 4.87 & 4.31 & 4.66 & 4.41 \\
\hline Ti IV & 3.41 & 3.62 & 2.81 & 3.19 & 2.98 & 3.11 & 3.00 \\
\hline
\end{tabular}

\section{Female}

With larger clavi inguines and longer coda than males. Males with thicker basitarsus (but not notably swollen) (Fig. 16B).

\section{Distribution}

Only known from type locality, in the WWF ecoregion Magdalena Valley montane forests (NT0136), tropical and subtropical moist broadleaf forest biome, in Santander Department (Fig. 33).

Eulibitia maculata Roewer, 1912

Figs 3, 19-22, 32; Table 3

Eulibitia maculata Roewer, 1912: 17, pl. 1, fig 1.

Libitia (Messa) castanea Sørensen in Henriksen, 1932: 415. syn. nov.

Eulibitia maculata - Roewer 1923: 298, fig 320. — Sørensen in Henriksen 1932: 389. - B. Soares 1945: 343. — Weidner 1959: 122. — Pinto-da-Rocha \& Hara 2011: 2.

Paramessa castanea - Mello-Leitão 1933: 109.

Messatana castanea - Strand 1942: 398.

\section{Diagnosis}

This species differs from the other species of Eulibitia by the absence of paramedian tubercles on the posterior margin of the scutum (Fig. 19D-E). The ladder mask can occupy the groove between areas III and IV (Fig. 20A, C-H). This species is similar to E. helena sp. nov. and E. clytemnestra sp. nov. by the shape of DS, with mid-bulge asymmetrical, but differs from the former by the absence of clavi inguines (Figs 19A, 20A) and by not having larger tubercles on distal femur IV (Fig. 21B-C), and from the latter by the presence of a row of tubercles on the lateral margins of DS (Fig. 20A).

\section{Etymology}

Maculata: Latin adjective, referring to the spots of the scutum. Castanea: Latin adjective, referring to the chestnut brown color. 


\section{Type material}

Lectotype (here designated)

COLOMBIA: $\hat{\jmath}$, Tolima (syntype of Eulibitia maculata, SMF RI/471, examined by photograph).

\section{Paralectotypes}

COLOMBIA: 3 $\Im+$, Tequendama (syntypes of Eulibitia maculata, SMF RI/458, not examined); 1 ऽ, Boca del Monte (syntype of Eulibitia maculata, SMF RI/469, not examined); 1 $\uparrow, 1$, , same collection data as for holotype (syntypes of Eulibitia maculata, ZMH coll. Roewer 458, examined by photograph).

\section{Syntypes}

COLOMBIA: 2 우, Cundinamarca Department, Bogotá (syntypes of Libitia castanea, BMNH, examined).

\section{Other material examined}

COLOMBIA: Boyacá Department - 1 đै, Villa de Leyva, SFF Iguaque $\left[5.720016^{\circ} \mathrm{N}, 73.457901^{\circ} \mathrm{W}\right]$, 2800 m a.s.1., 22 Sep. 2013, A. García and S. Galvis leg. (ICN-AO 1428); 1 , Chíquiza, Morro Negro, $5^{\circ} 36^{\prime} 36^{\prime \prime} \mathrm{N}, 7^{\circ} 29^{\prime} 20^{\prime \prime} \mathrm{W}, 3245 \mathrm{~m}$ a.s.l. (IAvH 15); 1 ô, same collection data as preceding

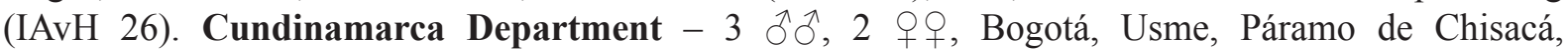
$4^{\circ} 17^{\prime} 1.87^{\prime \prime}$ N, $74^{\circ} 12^{\prime} 55.49^{\prime \prime}$ W, 3600 m a.s.1., 28 Feb. 1976, I. de Arevalo, R. Restrepo, students leg. (ICN-AO 93); 1 đ̃, 1 \%, Bogotá, Sierras del Chicó, 440'16.95" N, 74²'19.96" W, 15 May 2007, I. Morales leg. (ICN-AO 478); 1 ð’, 4 우, Bogotá, Usme, Cerro Juan Rey, Olla del Ramo, 4³1'19.68" N, $74^{\circ} 6^{\prime} 17.85^{\prime \prime}$ W, 25 Mar. 2003, stubble, pitfall, L. Benavides leg. (ICN-AO 491); 1 đે, Soacha, Vereda San Francisco, Granja Ecológica El Porvenir, 434'30.13" N, 74¹7'49.62" W, 2550 m a.s.1., 21 Nov. 2010, bracken, C. Cantor leg. (ICN-AO 784); 2 đో 1 , 1 + , Bogotá, Usme, Parque Entrenubes, Cerro Juan Rey, $4^{\circ} 31^{\prime} 17.71^{\prime \prime} \mathrm{N}, 7^{\circ} 5^{\prime} 51.29^{\prime \prime} \mathrm{W}, 2700 \mathrm{~m}$ a.s.1., 23-25 May 2003, high scrub, pitfall, L. Benavides leg. (ICN-AO 875); $3 \hat{\partial} \hat{\partial}, 2$ q 9 , same collection data as preceding (MNRJ 9272); $2 \hat{\partial} \widehat{\partial}$, San Antonio del Tequendama, Reserva Natural Los Tunos, $4^{\circ} 33^{\prime} 47.48^{\prime \prime}$ N, 74¹ $8^{\prime} 55.69^{\prime \prime}$ W, 2300 m a.s.1., 28 May 2012, D. Martínez leg. (ICN-AO 1048); 1 đ̄, 2 우, Guasca, Reserva Biológica El Encenillo, Andean High Forest, $4^{\circ} 47^{\prime} 1,92^{\prime \prime}$ N, $73^{\circ} 54^{\prime} 8,76^{\prime \prime}$ W, 3050 m a.s.l., 16 Sep. 2012, C. Suárez, A. Herrera, E. Henao, E. Ariza and C.Villalva leg. (ICN-AO 1103); 1 , La Calera, Club La Aguada, Embalse San Rafael, $4^{\circ} 42^{\prime 2} 25.71^{\prime \prime}$ N, $74^{\circ} 0^{\prime} 26.95^{\prime \prime}$ W, $2700 \mathrm{~m}$ a.s.1., Sep. 2000, D. Tovar and P. Chavarriaga leg. (ICN-AO 493); 3 우, Sibaté, San Miguel, going to Alto del Cuchuco, $4^{\circ} 26^{\prime} 55.98^{\prime \prime}$ N, $74^{\circ} 17^{\prime} 53.87^{\prime \prime}$ W, $2630 \mathrm{~m}$ a.s.1., 1 Dec. 1980, biology students leg. (ICN-AO 100).

\section{Description}

Male (based on ICN-AO 93)

Measurements. $\mathrm{CL}=2.23, \mathrm{AL}=3.91, \mathrm{CW}=3.08, \mathrm{AW}=5.32, \mathrm{Fe} \mathrm{IV}=4.58, \mathrm{Ti} \mathrm{IV}=4.07$.

Dorsum (Figs 19, 20A). Dorsal scutum beta-shaped, with asymmetrical mid-bulge, areas I-V unarmed. Lateral margins with irregular row of minute granules at mid-bulge. Posterior margin of scutum with row of small tubercles. Tergites with row of small tubercles and anal operculum finely granular.

VENTER (Fig. 19D-E). Free sternites finely granular; coxae II-IV finely and uniformly granular; coxa I with longitudinal row of tubercles and smooth area corresponding to lace area of pedipalp.

Chelicerae (Fig. 21F). Basichelicerite with ecto-basal row of six tubercles; movable finger serrulate, with basal tubercle larger than others; fixed finger with four tubercles decreasing in size from basal to distal part of finger. 
Pedipalps (Fig. 21D-E). Trochanter with strong ventral process. Femur with pronounced dorsal keel, with ventral row of seven setiferous tubercles and strong mesodistal process. Patella with mesal keel. Shallow slit along tibia mesal surface, separating dorsal and ventral sides.

LEgs (Fig. 21A-C). Coxa IV granulated, without clavi inguines. Trochanter IV with small retro-distal apophysis. Femur IV slightly arched, with two longitudinal ventral rows of small tubercles along entire length. Patella IV substraight, with small setiferous tubercles. Tarsal counts: 5-5/9-?/6-6/7-7.

COLOR (Fig. 19). Body and appendages color background 41 (Deep Reddish Brown) mottled in 59 (Dark Brown), ladder mask 104 (Pale Greenish Yellow). Trochanters I-III and tarsomeres 99 (Strong Greenish Yellow).
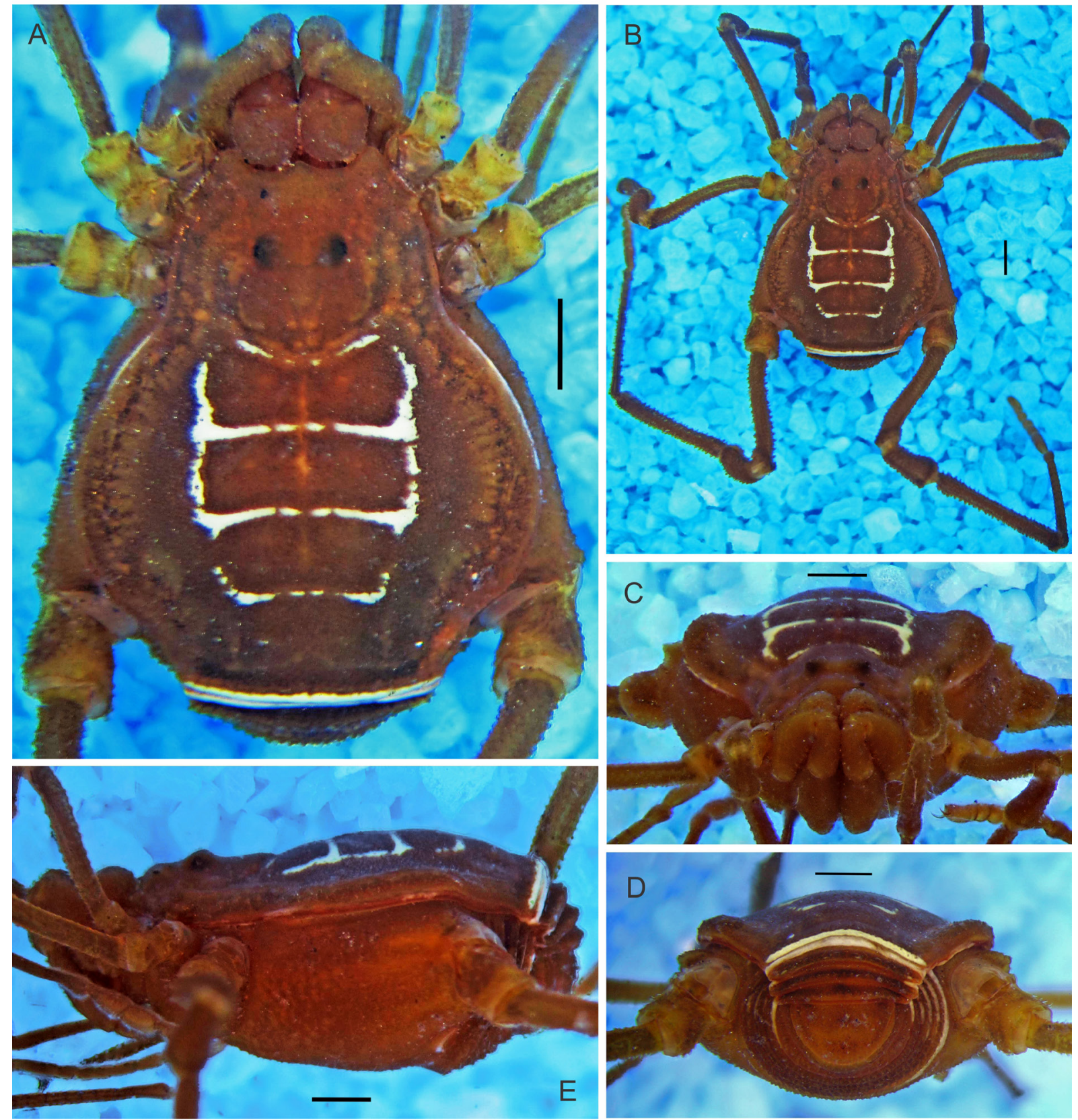

Fig. 19. Eulibitia maculata Roewer, 1912, ô (ICN-AO 93), habitus. A. Dorsal view. B. Panoramic, dorsal view. C. Frontal view. D. Posterior view. E. Lateral view. Scale bars: $1 \mathrm{~mm}$. 

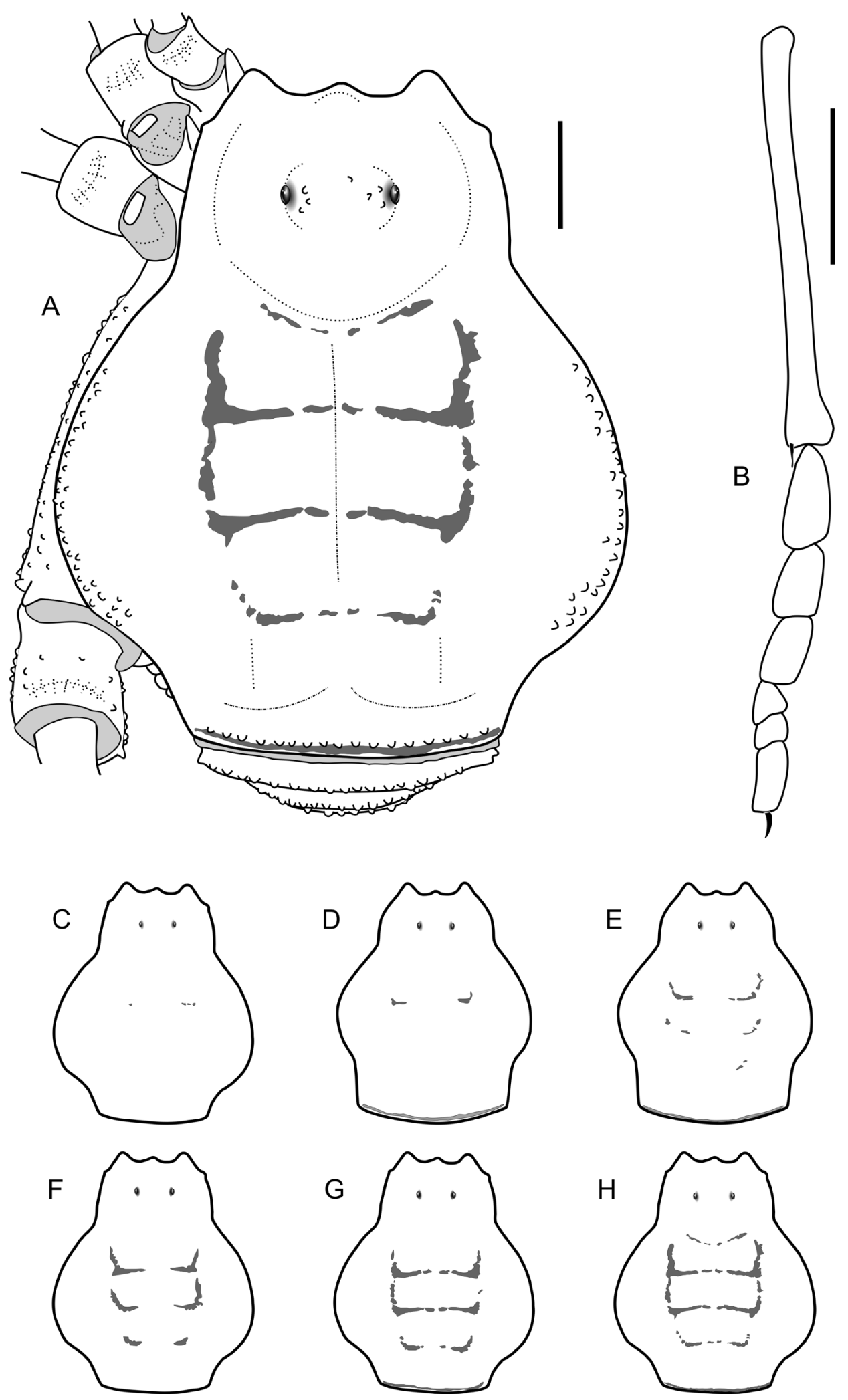

Fig. 20. Eulibitia maculata Roewer, 1912. A. Habitus, dorsal view, $\widehat{\partial}$ (ICN-AO 93). B. Left metatarsus and tarsomeres of leg I, prolateral view (ICN-AO 93). C-H. Variation of spot pattern on dorsal scutum.

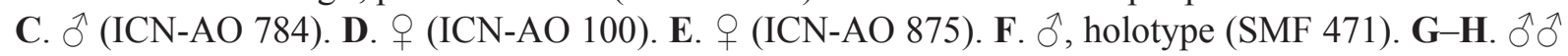
(ICN-AO 93). Scale bars: $1 \mathrm{~mm}$. 
Genitalia (Figs 3, 22). Ventral plate of penis subrectangular, narrower basally, with lateral borders subparallel and distal border slightly straight; dorsal apophysis of glans subsquare, wattle of stylus long. Shape and organization of macrosetae as follows: MS C1-C2 large, curved and flat; MS D1 large and slightly curved, D2 straight and half size of D1, both more dorsal than other MS; MS A1-A2 large, straight, cylindrical and located almost in basal middle of ventral plate; MS B and MS E1-E2 ventral, very small and immersed in microsetae. MS B most basal MS. Microsetae confined to lateral margins of ventral plate.
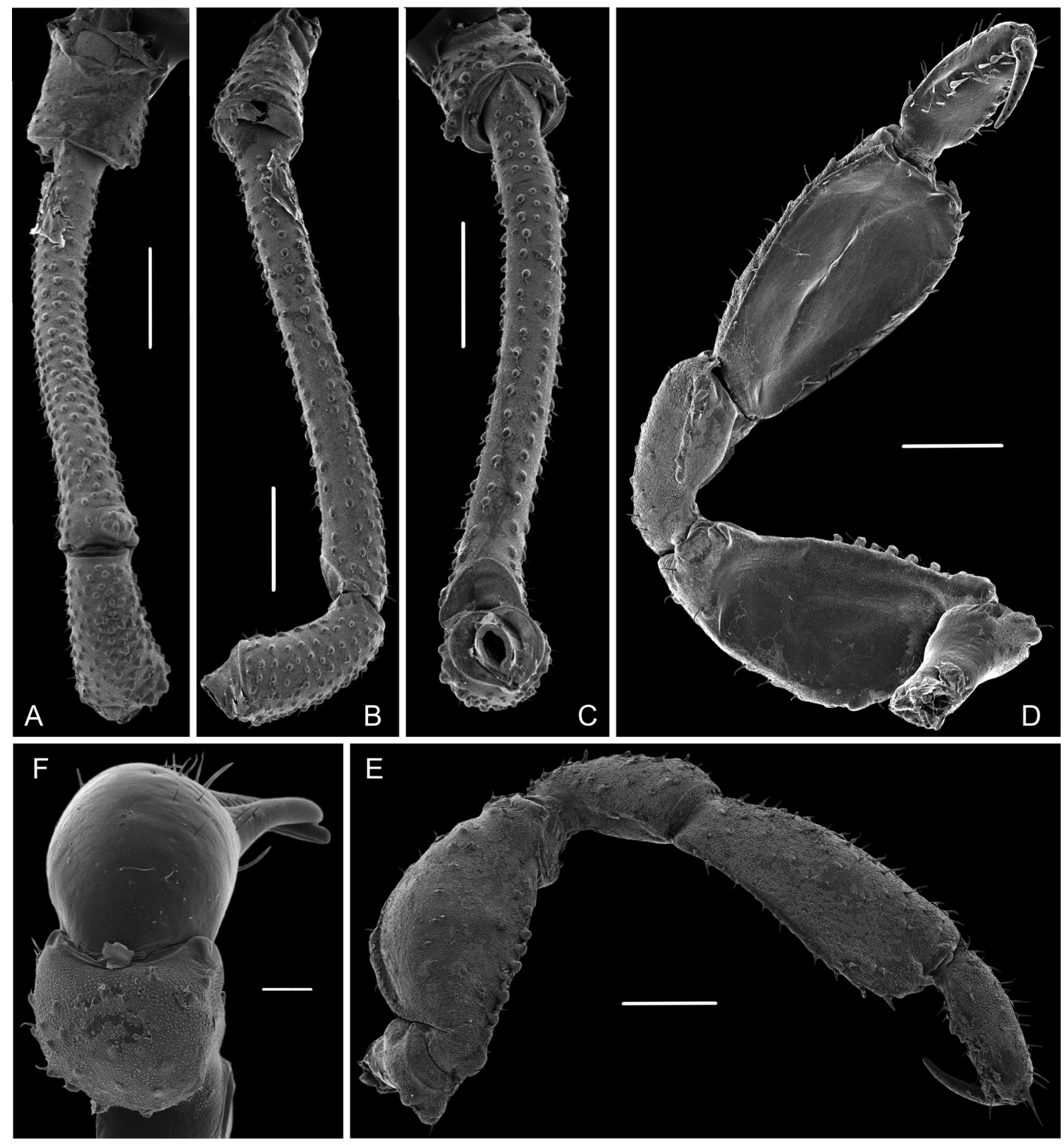

Fig. 21. Eulibitia maculata Roewer, 1912, § (ICN-AO 875). A. Trochanter, femur and patella of leg IV, dorsal view. B. Same, prolateral view. C. Same, ventral view. D. Left pedipalpus, mesal view. E. Same, ectal view. F. Left chelicera, dorsal view. Scale bars: A-C $=1 \mathrm{~mm}$; D-E $=500 \mu \mathrm{m} ; \mathrm{F}=200 \mu \mathrm{m}$. 


\section{Variation}

Pattern of yellow spots as in Fig. 20C-H. MS A of VP of penis may be variable and asymmetrical in number from two to three, as shown in Figs 3 and 22, corresponding to two specimens from same lot. Tarsal counts: $5-6 ; 9-10 ; 6 ; 6-7$. Variation of measurements is given in Table 3.

\section{Female}

Subtly smaller than males, with coda longer (Fig. 20C-D). Males with basitarsus thicker but not notably swollen (Fig. 20B).

\section{Distribution}

Eulibitia maculata occurs in the WWF ecoregions: (1) Magdalena Valley montane forests (NT0136), tropical and subtropical moist broadleaf forest biome, and (2) Northern Andean páramo (NT1006),
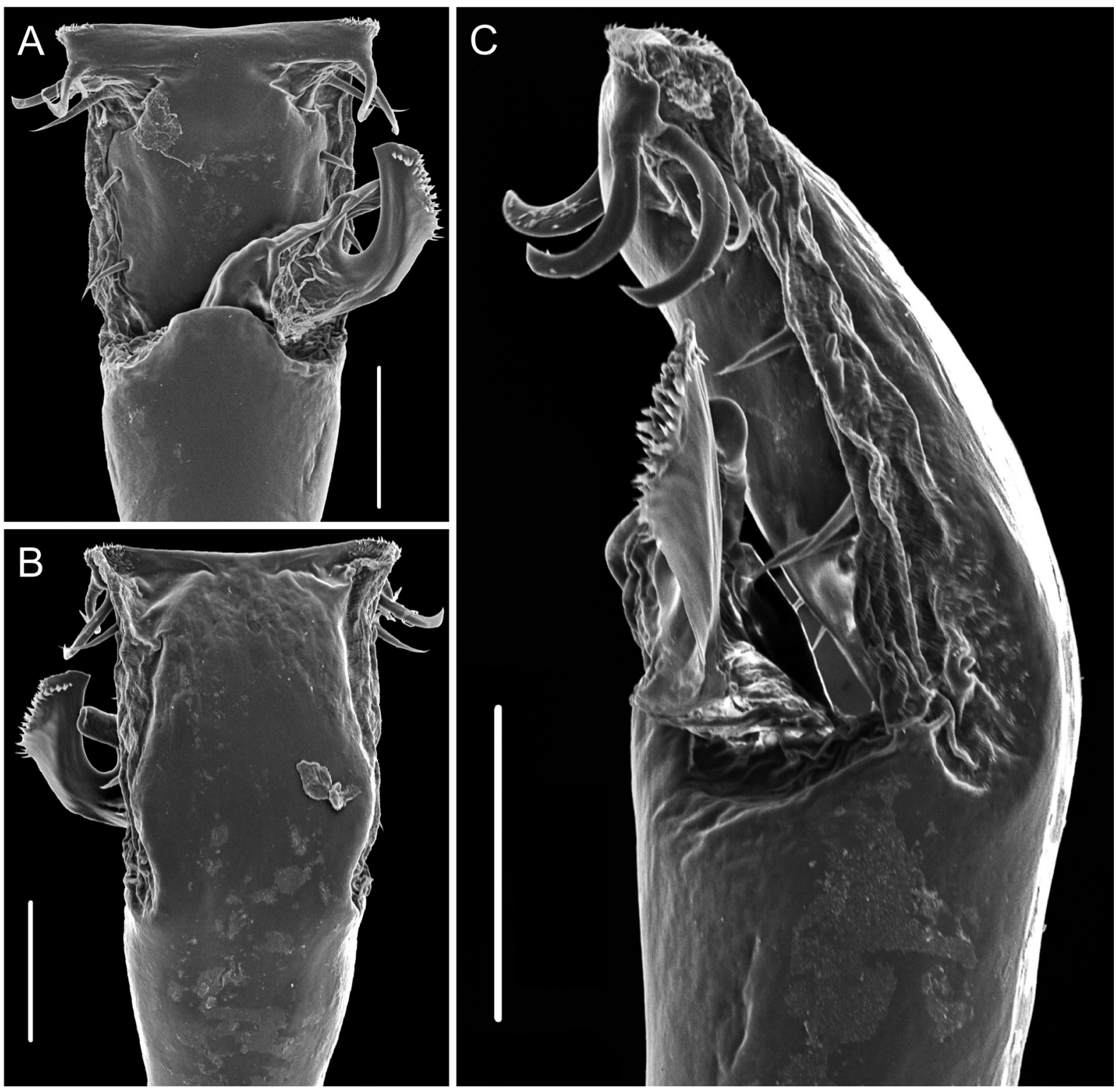

Fig. 22. Eulibitia maculata Roewer, 1912, $\widehat{~}$ (ICN-AO 875, different specimen than used in Fig. 2A-B), distal part of penis. A. Dorsal view. B. Ventral view. C. Lateral view. Scale bars: $100 \mu \mathrm{m}$. 


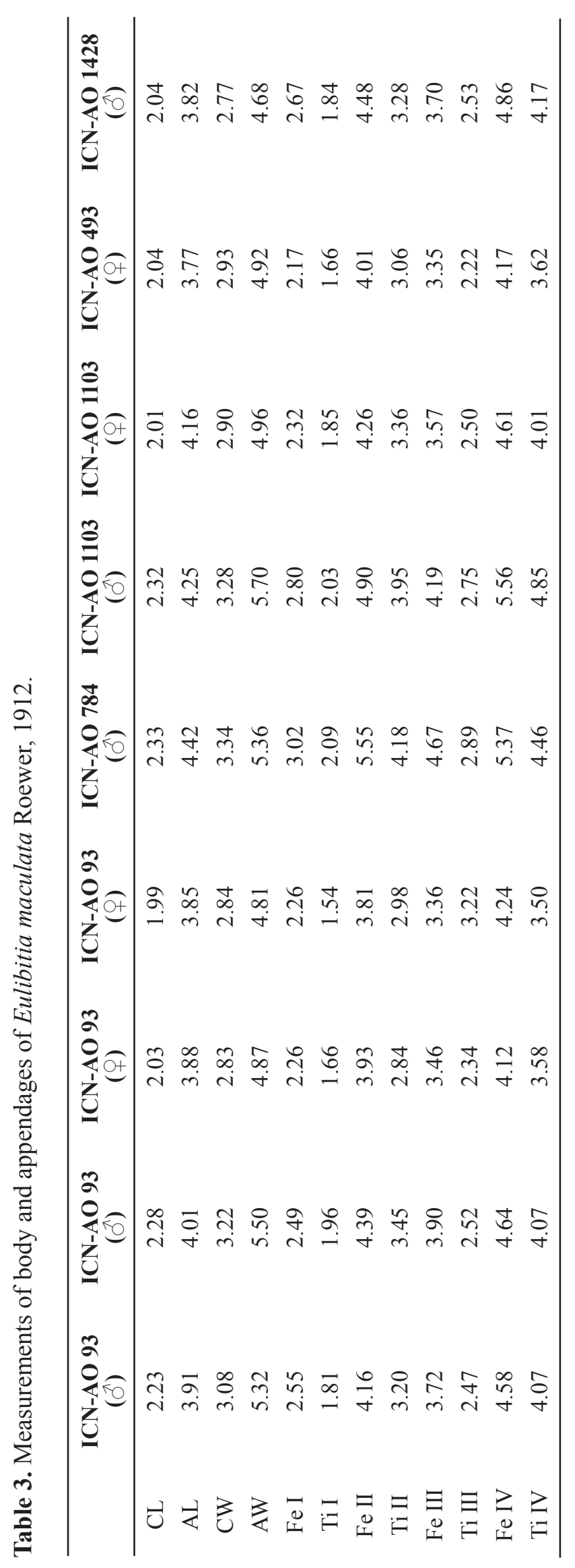


montane grassland and shrubland biome; in Tolima, Cundinamarca and Boyacá Departments (Fig. 32). The localities given by Roewer for Eulibitia maculata are rather imprecise: Tolima (Roewer 1912) and "Neu Granada" (Roewer 1923; probably referring to Viceroyalty of New Granada, territory corresponding to modern Colombia, Ecuador, Panama, and Venezuela under the jurisdiction of the Spanish Empire until 1819). Tolima Department has an area of $23.562 \mathrm{~km}^{2}$ and four WWF ecoregions can be distinguished in it; here, a point in NT0136 of the eastern region of the department was chosen to coincide with the other points of occurrence of the species.

\section{Remarks}

Although Roewer (1912) described various characteristics of the specimen ZMH 458, he labeled the lectotype SMF RI/471 as "Type", which does not entirely match the original description and certainly is a different species. Therefore, the use of ZMH 458 ("ex-typo", probably belonging to Ambatoiella) has masked the identity of the real Eulibitia (see for example Pinto-Da-Rocha \& Hara 2011, who mentioned characteristics of ZMH 458 in their table 1, although they cited SMF RI/471 as the "holotype" in their text).

The paralectotype ZMH 458 (used for original description) differs from the lectotype (designated here) by: (1) abdominal scutum reaching its maximum width in scutal area II (vs area III in the lectotype); (2) scutal area IV and the posterior margin with two small tubercles; (3) coda long, of same length as the mid-bulge; (4) ectal border of protoglyphs bifurcated, and (5) presence of clavi inguines. The use of those features by Roewer (1928) and Mello-Leitão $(1932,1933)$ to diagnose the genus, masked the identity of Eulibitia and made the detection of synonymies problematic.

The species Paramessa castanea was considered a different species from Eulibitia maculata, possibly for two reasons: (1) the blot pattern of DS, which is absent in the holotype of $P$. castanea, and the full ladder mask in the lectotype of E. maculata (see Figs 20C-H for variation); or (2) the designation of different species in the type series, since Roewer designated ZMH specimens of a species more similar to Ambatoiella as paratypes, as explained above.

Eulibitia pollux sp. nov. urn:1sid:zoobank.org:act:522C7A02-61AC-45D7-8F84-C42E01F1EC46

Figs 23-26, 31B, 34; Table 4

\section{Diagnosis}

This species is similar to E. castor sp. nov. in having the paramedian tubercles on the posterior margin of the scutum acuminate, but differs from it because the other areas are unarmed (Figs 23A-B, D-E, 24A). Ladder mask often as paired points in scutal grooves (Fig. 24C); in its full form it covers the scutal groove between areas I and II with a spot with a shape of a mustache (Fig. 24F). Coda short, with symmetrical mid-bulge (Figs 23A, 24A); coxa IV slightly granulated, without clavi inguines (Fig. 24A). Femur IV curved in dorsal view, without conspicuous ornamentation (Fig. 25A-C). This is the only species of Eulibitia in which macrosetae D2 are minute, of the same size as MS E and MS B (Fig. 26B).

\section{Etymology}

Noun in apposition from Pollux, son of Leda and Zeus, and twin of Castor. From Greek mythology.

\section{Material examined}

\section{Holotype}

COLOMBIA: $\widehat{\jmath}$, Boyacá Department, Villa de Leyva, Santuario de Fauna y Flora Iguaque, El Níspero $\left[5^{\circ} 38^{\prime} \mathrm{N}, 73^{\circ} 31^{\prime} \mathrm{W}\right](\mathrm{IAvH} 35)$. 


\section{Paratypes}

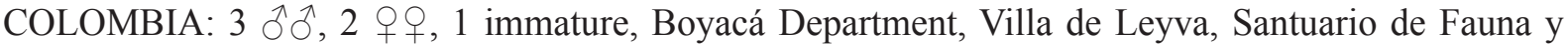
Flora Iguaque, $5^{\circ} 42^{\prime} 6.3^{\prime \prime} \mathrm{N}, 7^{\circ} 27^{\prime} 22.4^{\prime \prime} \mathrm{W}, 2941$ m a.s.1., 26-27 Nov. 2011, A. García and AB Kury leg. (MNRJ 19369); 1 đ̃, 1 ㅇ, Boyacá Department, Villa de Leyva, SFF Iguaque, 5.7200 N, 73.4579 ${ }^{\circ} \mathrm{W}$, 2800 m a.s.1., 22 Sep. 2013, A. García and S. Galvis leg. (ICN-AO 1379).

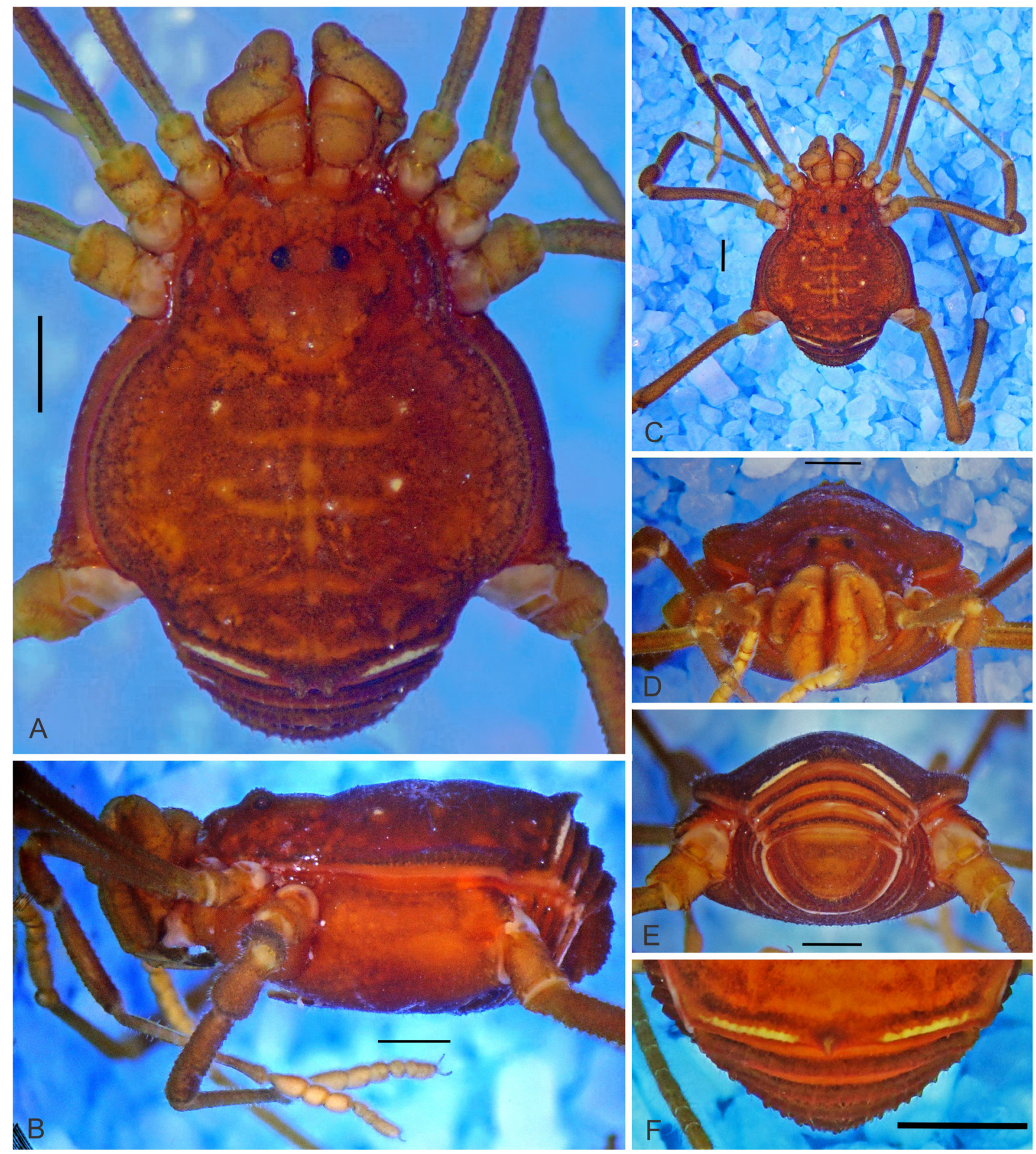

Fig. 23. Eulibitia pollux sp. nov., Ô, paratype (MNRJ 19369), habitus. A. Dorsal view. B. Left lateral view. C. Panoramic, dorsal view. D. Frontal view. E. Posterior view. F. Detail of another paratype with a single spine on posterior margin of scutum. Scale bars: $1 \mathrm{~mm}$. 


\section{Other material}

COLOMBIA: Boyacá Department $-1 \hat{\jmath}$, Villa de Leyva, SFF Iguaque, sector Carrizal, $5^{\circ} 41^{\prime} 52.28^{\prime \prime} \mathrm{N}, 73^{\circ} 27^{\prime} 11.28^{\prime \prime} \mathrm{W}, 9$ Jun. 2001, E. Flórez leg. (ICN-AO 295); 2 우우, Villa de Leyva, SFF Iguaque 5.720016 ${ }^{\circ}$ N, 73.457901 ${ }^{\circ}$ W, 2800 m a.s.l., 22 Sep. 2013, A. García and S. Galvis leg. (ICN-AO 1427); 2 우, Villa de Leyva, Santuario de Fauna y Flora Iguaque, El Níspero [5 $5^{\circ} 38^{\prime} \mathrm{N}$,

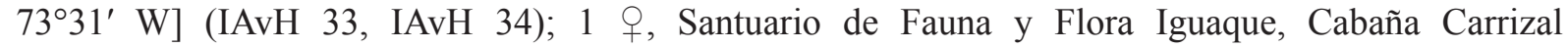

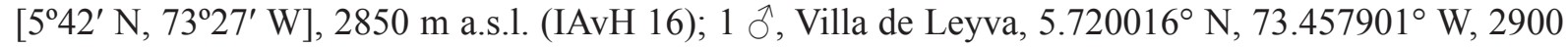
$\mathrm{m}$ a.s.l. (IAvH 18); 6 우, San Pedro de Iguaque [Chiquiza], Morro Negro [5 $5^{\circ} 36^{\prime} 36^{\prime \prime} \mathrm{N}, 73^{\circ} 29^{\prime} 20^{\prime \prime} \mathrm{W}$ ],

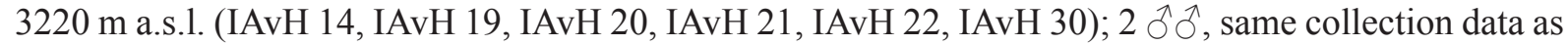
preceding(IAvH27, IAvH 66); 1 ð, same locality as preceding, 3220 ma.s.1., 14-16 May 2003, E. González and C. Reina leg. (IAvH 81); $2 \partial^{\lambda}$, Santuario de Faunay Flora Iguaque, Cabaña Carrizal [ $5^{\circ} 42^{\prime} \mathrm{N}, 73^{\circ} 27^{\prime} \mathrm{W}$ ], 2850 ma.s.l.(IAvH 23, IAvH 24); 1 ${ }^{\lambda}$, Villa de Leyva, Laguna Iguaque $\left[5.642778^{\circ} \mathrm{N}, 73.564722^{\circ} \mathrm{W}\right], 2800$ m a.s.l. (IAvH 28); 1 , , Santuario de Fauna y Flora Iguaque, Quebrada Los Francos [5.700 $\left.{ }^{\circ} \mathrm{N}, 73.450^{\circ} \mathrm{W}\right]$, $2860 \mathrm{~m}$ a.s.1. (IAvH 31); 1 đ, Villa de Leyva, SFF Iguaque, $5.7200^{\circ} \mathrm{N}, 73.4579^{\circ} \mathrm{W}, 2750 \mathrm{~m}$ a.s.1., Mar. 1993 (ICN-AO 474). Cundinamarca Department - 4 ㅊํ, 3 우우, Bogotá, Usme, Parque Entrenubes, Cerro Juan Rey, 4³1'17.71" N, 745'51.29" W, 2700 m a.s.1., 23-25 May 2003, high scrub, pitfall, L. Benavides leg. (ICN-AO 422); 1 , Parque Nacional Natural Chingaza, Vereda San Francisco,

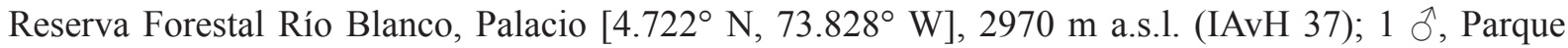
Nacional Natural Chingaza, Alto de La Bandera $\left[4.5167^{\circ} \mathrm{N}, 73.750^{\circ} \mathrm{W}\right], 3660 \mathrm{~m}$ a.s.l. (IAvH 65). -

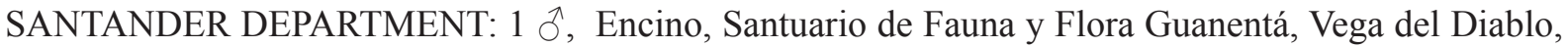
Río Negro [5.950 $\mathrm{N}, 73.183^{\circ} \mathrm{W}$ ], $1900 \mathrm{~m}$ a.s.l. (IAvH 95); 2 q 9 , same collection data as preceding (IAvH 96, IAvH 97). Valle del Cauca Department $-1{ }^{\circ}$, Palmira $\left[3.531^{\circ} \mathrm{N}, 76.260^{\circ} \mathrm{W}, 1040 \mathrm{~m}\right.$ a.s.1.], 22 May 1998, J. Herrera leg. (ICN-AO 1105).

\section{Description}

Male (based on holotype)

MeAsurements. $\mathrm{CL}=1.86, \mathrm{AL}=3.30, \mathrm{CW}=2.80, \mathrm{AW}=4.20, \mathrm{Fe} \mathrm{IV}=4.27, \mathrm{Ti} \mathrm{IV}=3.45$.

Dorsum (Figs 23, 24A). Dorsal scutum beta-shaped, with symmetrical mid-bulge. Posterior margin of scutum with two contiguous acuminate paramedian tubercles. Lateral margins of scutum granulated. Posterior margin of scutum with a row of small tubercles. Tergites with row of small tubercles and anal operculum finely granular.

Venter (Fig. 23B, E). Free sternites finely granular; coxae II-IV finely and uniformly granular; coxa I with longitudinal row of tubercles and smooth area matching interlocking $\operatorname{Tr}$ of pedipalpus.

Chelicerae (Fig. 25F). Basichelicerite with row of seven small tubercles on basal side and some disperse tubercles on dorsal side; movable finger with row of eleven tubercles, giving a serrated appearance; fixed finger with five tubercles, decreasing in size from basal to distal part of finger.

Pedipalps (Fig. 25D, E). Trochanter with strong ventral process. Femur with pronounced dorsal row of seven separated tubercles, with ventral row of seven setiferous tubercles and mesodistal process. Patella with low mesal keel.

LEgs (Figs 24B, 25A-C). Coxa IV finely granulated, without clavi inguines, distal apophysis of coxa IV tuberculate and directed laterally. Trochanter IV with small retro-distal apophysis. Femur IV curved in dorsal view, with two longitudinal ventral rows of small tubercles along entire length. Patella IV substraight, with small tubercles. Tarsal counts: 6-6(3)/10-10(3)/6-6/7-7.

Color (Fig. 23). Body and appendages color background 40 (Strong Reddish Brown) mottled in 44 (Dark Reddish Brown), ladder mask 104 (Pale Greenish Yellow). Pedipalpus, chelicerae, and trochanters and tarsomeres of legs 83 (Brilliant Yellow). 

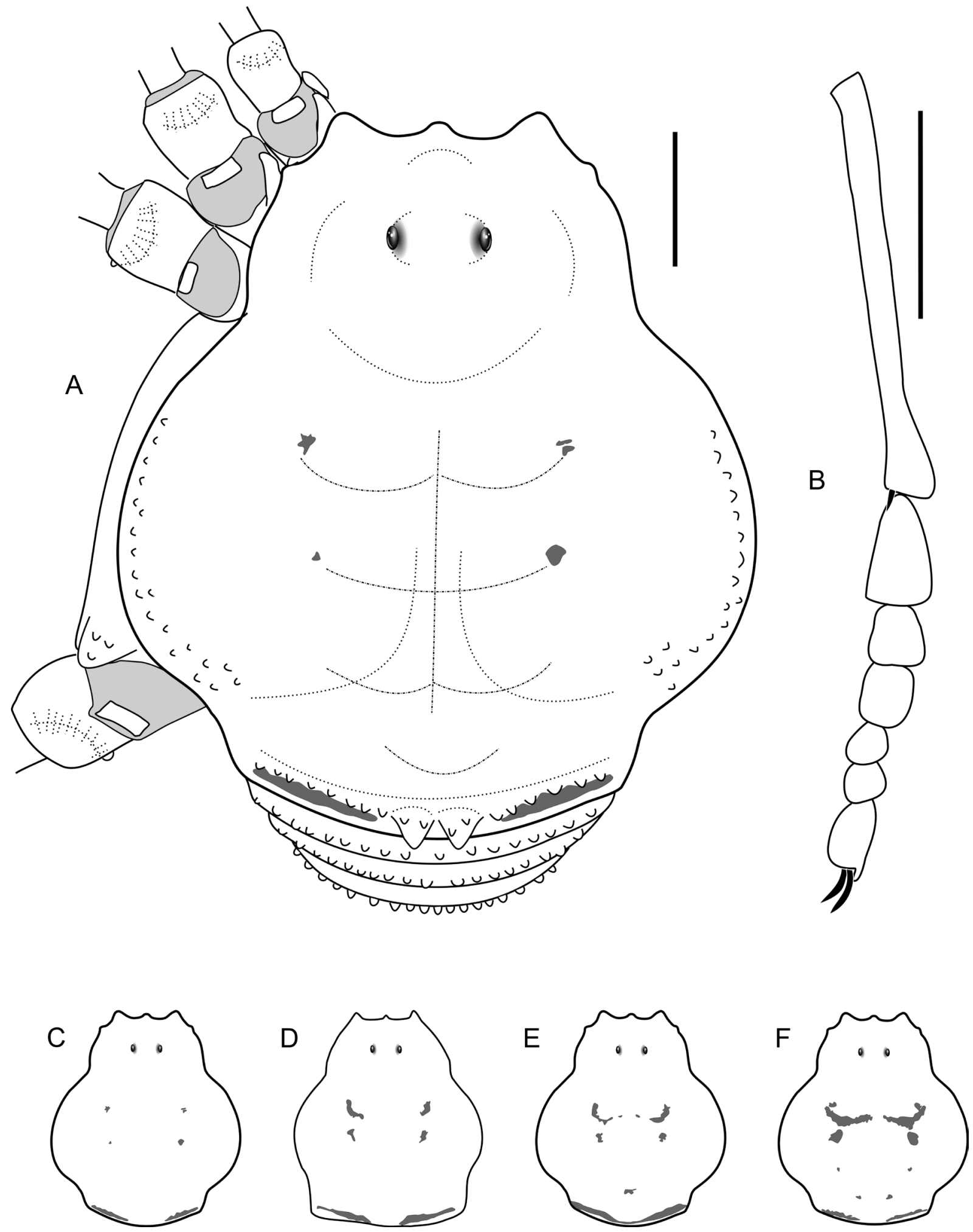

Fig. 24. Eulibitia pollux sp. nov., Ô, paratype (MNRJ 19369). A. Habitus, dorsal view. B. Left metatarsus and tarsomeres of leg I, prolateral view. C-F. Variation of spot pattern on dorsal scutum. C. § (MNRJ 19369). D. + (ICN-AO 422). E. ô (ICN-AO 422). F. $\widehat{o}$ (IAvH 97). Scale bars: 1 mm. 
Genitalia (Fig. 26). Ventral plate subrectangular, narrower basally and distal border hardly concave; dorsal apophysis of glans long and narrow, wattle long. Shapes and organization of macrosetae as follows: MS C1-C2 large, curved and flat; MS D1 large and straight, D2 minute; MS A1-A2 large,
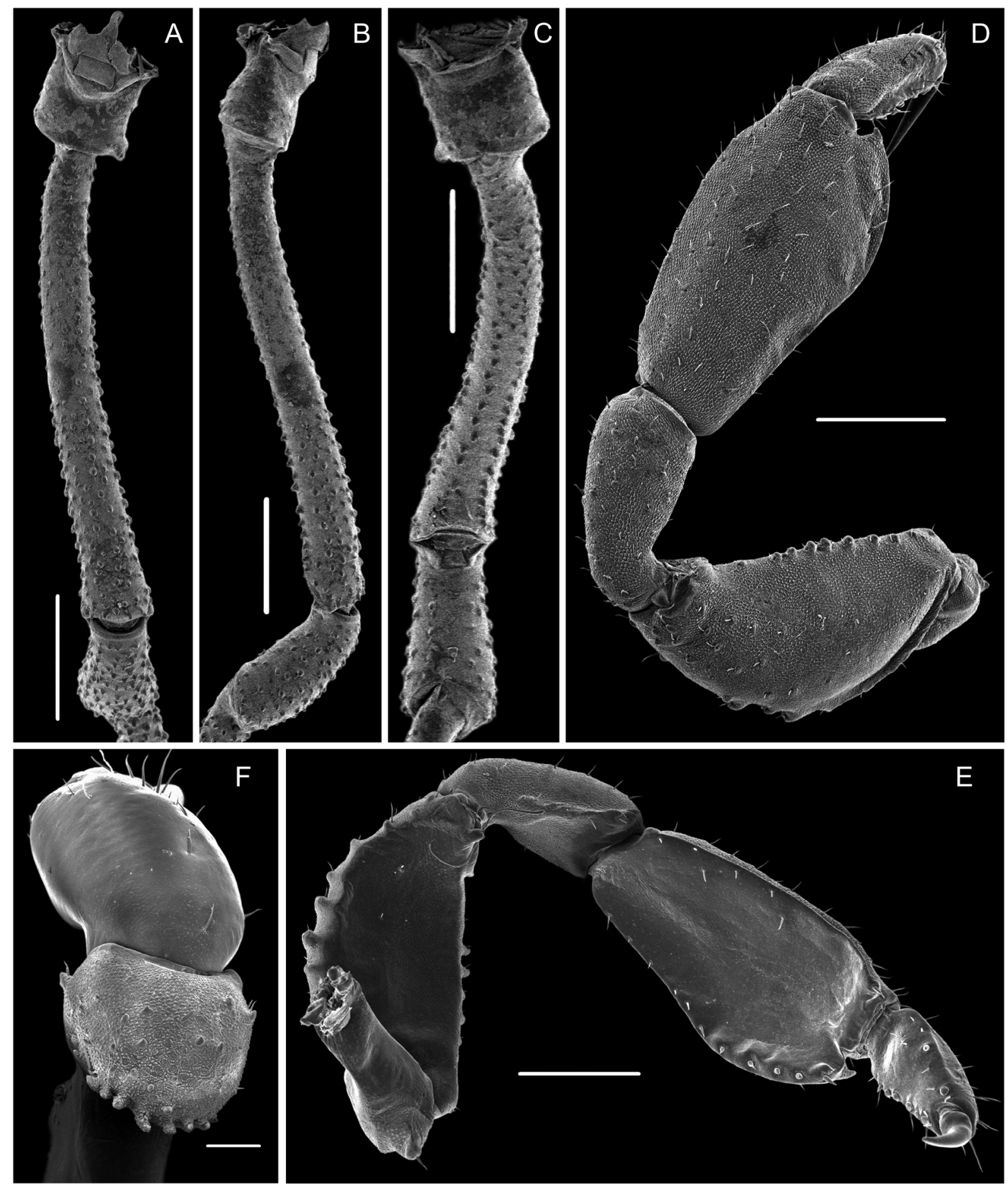

Fig. 25. Eulibitia pollux sp. nov., ô (ICN-AO 422). A. Trochanter, femur and patella of leg IV, dorsal view. B. Same, prolateral view. C. Same, ventral view. D. Left pedipalpus, ectal view. E. Same, mesal view. F. Left chelicera, dorsal view. Scale bars: A-C $=1 \mathrm{~mm}$; D-E $=500 \mu \mathrm{m} ; \mathrm{F}=200 \mu \mathrm{m}$. 


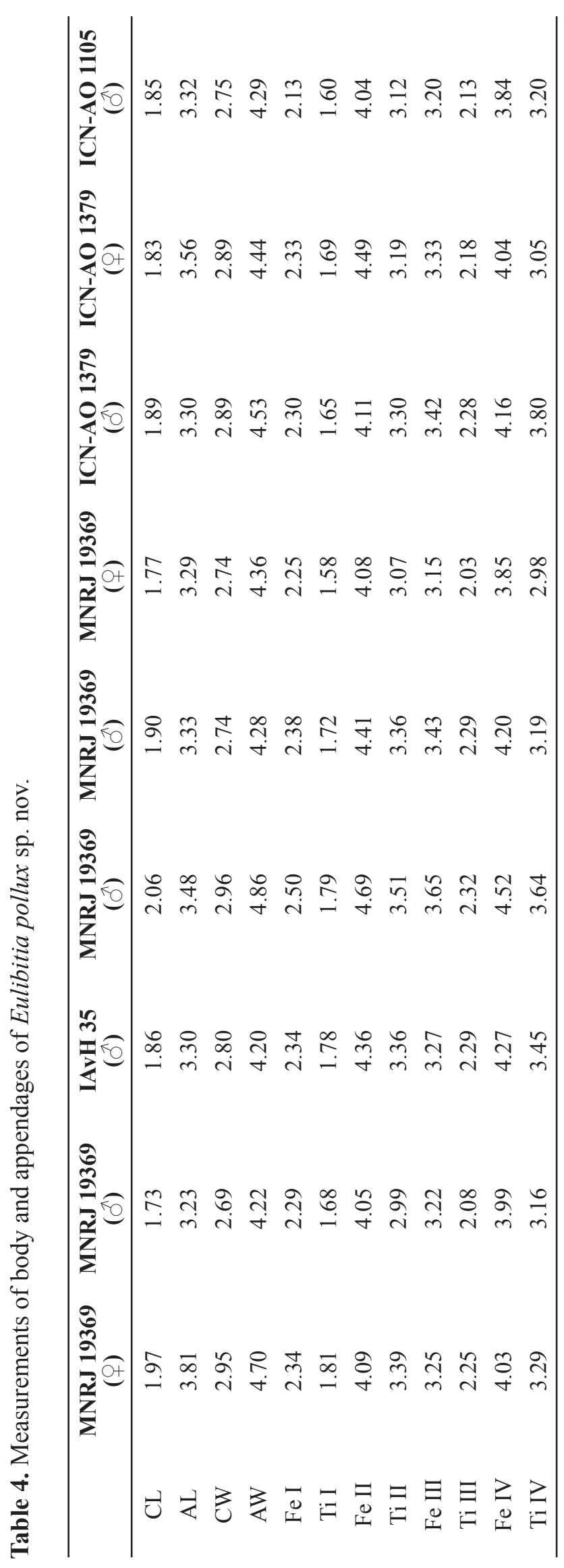


cylindrical, straight and located in middle of ventral plate; MS B and MS E1-E2 ventral, very small, immersed in microsetae. Pair of MS B at base of ventral plate.

\section{Variation}

Right tubercle of posterior margin absent in some specimens (Fig. 23F). Variation of spots in DS as shown in Fig. 24C-F. Tarsal counts: 5-6; 8-11; 6; 6-7. Variation of measurements is given in Table 4.

\section{Female}

Coda larger than in males (Fig. 24C-D). Basitarsomeres in legs I thickened but not swollen (Fig. 24B).

\section{Distribution}

E. pollux sp. nov. occurs in the WWF ecoregions: (1) Magdalena Valley montane forests (NT0136), tropical and subtropical moist broadleaf forest biome; (2) northern Andean páramo (NT1006), montane grassland and shrubland biome, and (3) Cauca Valley montane forests (NT0109), tropical and subtropical moist broadleaf forest biome (Fig. 34).

Eulibitia scalaris (Sørensen, 1932) comb. nov.

Figs 27-30, 31A, 33; Table 5

Libitia (Messa) scalaris Sørensen in Henriksen, 1932: 414.

Acromares lateralis Goodnight \& Goodnight, 1943: 2, fig 7. syn. nov.

Messa scalaris - Mello-Leitão 1933: 112.

Messatana scalaris - Strand 1942: 398.

Cynorta lateralis - Goodnight \& Goodnight 1953: 38.

Acromares lateralis - Flórez \& Sánchez 1995: 368. — Kury 2003: 37.

\section{Diagnosis}

This species is similar to E. h-inscriptum by having paramedian tubercles in areas I, III and on the posterior margin of the scutum, but differs from it because its ladder mask does not reach the lateral margins of the scutum (Fig. 28C-H), and from the other species of Eulibitia by the size of the coda (Fig. 27A), $1 / 3$ of the mid-bulge length (vs $1 / 4$ of the mid-bulge length in other species, except E. h-inscriptum). It is similar to E. castor sp. nov. by having two paramedian tubercles in areas I, III
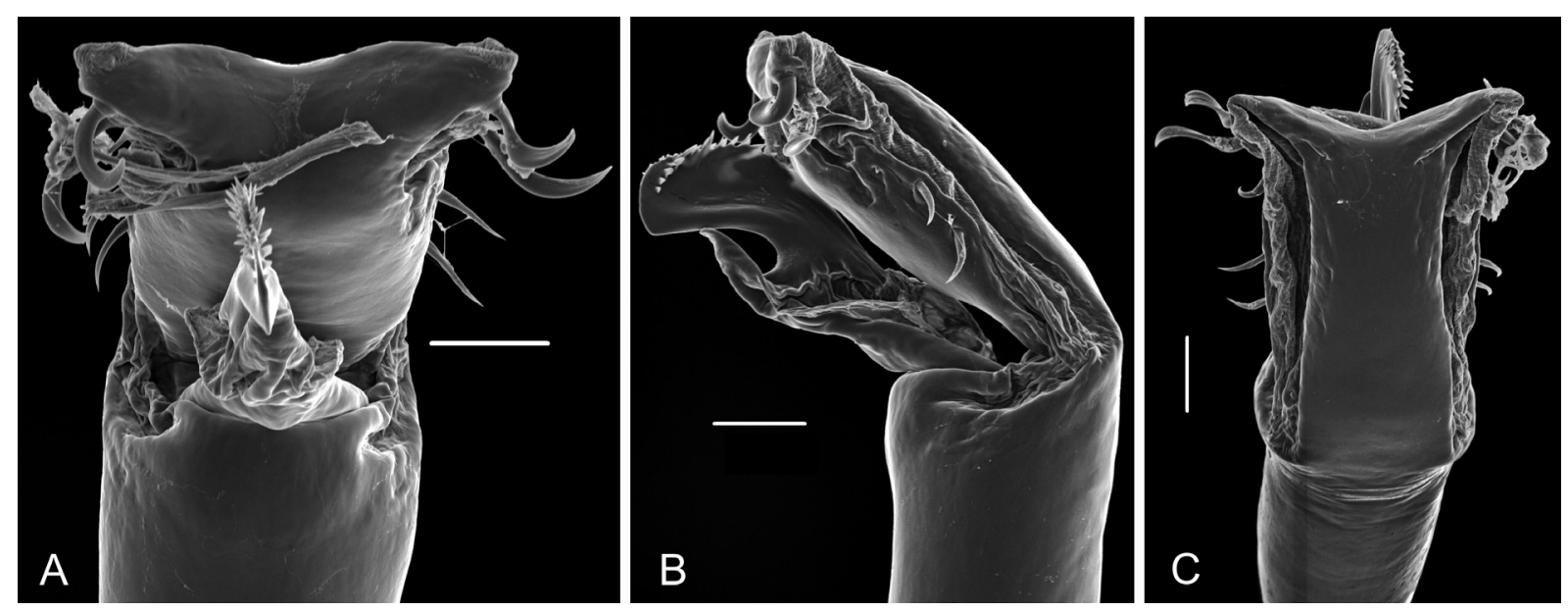

Fig. 26. Eulibitia pollux sp. nov., ô (MNRJ 19369), distal part of penis. A. Dorsal view. B. Lateral view. C. Ventral view. Scale bars: $50 \mu \mathrm{m}$. 
and on the posterior margin, and for the symmetrical mid-bulge, but it differs from it by the shape of the tubercles on the posterior margin, being rounded instead of acuminate (Fig. 28A).

\section{Etymology}

Scalaris: refers to the shape of the ladder of white blots on DS. Lateralis: refers to the rails of the ladder mask on DS (visible in the holotype of Acromares lateralis).

\section{Material examined}

\section{Syntypes}

COLOMBIA: $2 \hat{\jmath} \widehat{\jmath}, 2$ 우, Cundinamarca Department, Bogotá (BMNH, examined by photograph).

\section{Other material}

COLOMBIA: Boyacá Department - 1 q, Chiquinquirá, Monte Batallón Sucre, 5³5'59.33" N, $73^{\circ} 50^{\prime} 9.28^{\prime \prime}$ W, 2580 m a.s.1., 24 May 1979, C. Hernandez leg. (ICN-AO 56); 4 $\partial^{\jmath}, 7$ 웅, Paipa, La

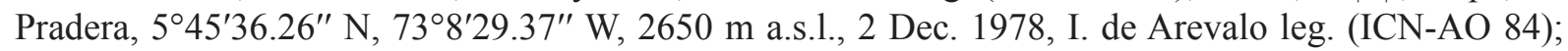
2 우, Arcabuco, $5^{\circ} 45^{\prime} 0^{\prime \prime} \mathrm{N}, 7^{\circ} 28^{\prime} 45^{\prime \prime} \mathrm{W}, 2500 \mathrm{~m}$ a.s.1., S. Sierra leg. (ICN-AO 221); $1 \mathrm{O}^{\prime}$, Arcabuco, $5.75012^{\circ}$ N, $73.433482^{\circ}$ W, 2600 m a.s.1., 23 Sep. 2013, A. García and S. Galvis leg. (ICN-AO 1202);

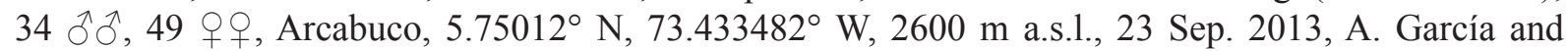
S. Galvis leg. (ICN-AO 1208); 7 $\widehat{\partial}, 6$ 우우, Villa de Leyva, SFF Iguaque, $5.720016^{\circ} \mathrm{N}, 73.457901^{\circ} \mathrm{W}$, 2800 m a.s.1., 22 Sep. 2013, A. García and S. Galvis leg. (ICN-AO 1214); 2 $\partial^{\jmath}, 3$ q $q$, Arcabuco, $5.75012^{\circ}$ N, $73.433482^{\circ}$ W, 2600 m a.s.1., 23 Sep. 2013, A. García and S. Galvis leg. (ICN-AO 1372);

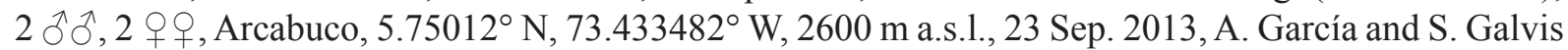
leg. (ICN-AO 1378); 2 우, Villa de Leyva, SFF Iguaque, Cabaña Chaina, Lado Río, $5^{\circ} 42^{\prime} \mathrm{N}, 73^{\circ} 27^{\prime} \mathrm{W}$, $2600 \mathrm{~m}$ a.s.l. (IAvH 40, IAvH 42); 1 ${ }^{\lambda}$, same collection data as preceding (IAvH 41); 1 q, Villa de Leyva, Colegio Antonio Nariño, $5.63^{\circ} \mathrm{N}, 73.527^{\circ} \mathrm{W}, 2200 \mathrm{~m}$ a.s.l. (IAvH 46); 1 q, Arcabuco, near El Cometa, $5.7439^{\circ} \mathrm{N}, 73.4713^{\circ} \mathrm{W}$ (IAvH 53); 1 ㅇ, Villa de Leyva, Colegio Antonio Nariño, 5.63 $\mathrm{N}, 73.527^{\circ} \mathrm{W}$, 2200 ma.s.1.(IAvH93); $1 \mathrm{O}^{\widehat{ }}$, Villa de Leyva, ColegioAntonio Nariño, $5.63^{\circ} \mathrm{N}, 73.527^{\circ} \mathrm{W}, 2200 \mathrm{~m}$ a.s.1.(IAvH 94); $1 \hat{O}^{\lambda}, 4$ 우, Villa de Leyva, SFF Iguaque, $5^{\circ} 42^{\prime} \mathrm{N}, 73^{\circ} 27^{\prime} \mathrm{W}, 2941 \mathrm{~m}$ a.s.1., Nov. 2011, A. Garcia and AB Kury leg. (MNRJ 19380). Cundinamarca Department - 1 ô, Susa, Vereda La Fragua, Finca Bermejales, $5^{\circ} 25^{\prime} 37.90^{\prime \prime} \mathrm{N}, 73^{\circ} 49^{\prime} 11.81^{\prime \prime} \mathrm{W}, 2710 \mathrm{~m}$ a.s.1., 30 Dec. 2006, J. Pinzon and G. Alarcón leg. (ICN-AO 481); 2 우, , Soacha, Vereda San Francisco, Granja Ecológica El Porvenir, 434'30.13" N, 74¹7'49.62" W, 10 Jul. 2009, pastureland, fallen trunk, G. Amat, C. Cantor, I. Romero and D. Martínez leg. (ICN-AO 602);

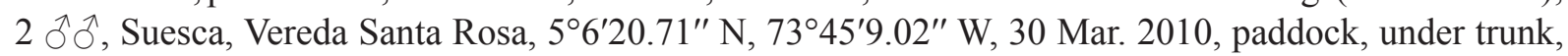

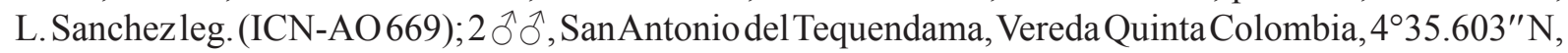
74²0.170" W, 1733 m a.s.1., 20 Aug. 2008, R. Botero, D. Luna and J. A. Ochoa leg. (ICN-AO 792);

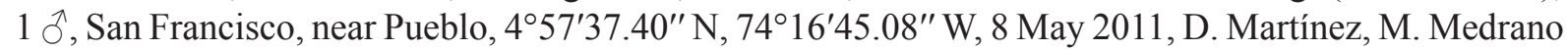

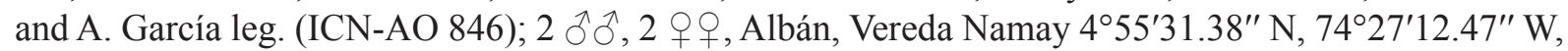

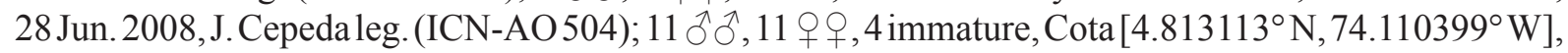
30 Aug. 2006, A. Giupponi leg. (MNRJ 17948); 1 ${ }^{\text {}}$, Mosquera, Sabrinsky $\left[4.688968^{\circ}\right.$ N, $\left.74.271632^{\circ} \mathrm{W}\right]$,

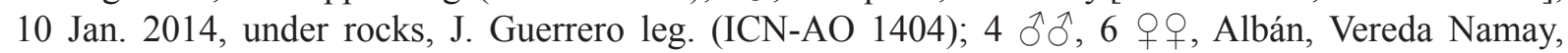
$4^{\circ} 55^{\prime} 31.38^{\prime \prime}$ N, 74²7'12.47" W, 1584 m a.s.1., Oct. 2007-Aug. 2008, Cafetal, J. Cepeda, C. Cantor and

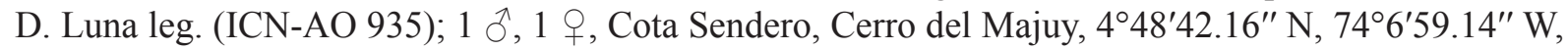

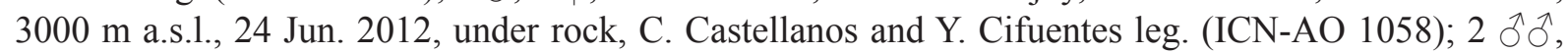
2 우, 시, Albán, Vereda Namay, $4^{\circ} 55^{\prime} 31.38^{\prime \prime}$ N, 74²7'12.47" W, 28 Jun. 2008, J. Cepeda leg. (ICN-AO 504); 1 đ , 1 ㅇ, Albán, Reserva Natural Peñas del Aserradero, $4.875959^{\circ} \mathrm{N}, 74.422635^{\circ} \mathrm{W}, 2630 \mathrm{~m}$ a.s.1., Aug. 2013, under trunk, M. Medrano, E. Flórez, A. Sabogal and D. Martínez leg. (ICN-AO 1387); 2 우우, 1 immature, Chocontá, Vereda Boquerón Bajo, Finca Nápoles, 5.094417 N, 73.670240 W, 13 Feb 2015, A. García and T. Rodrígues leg. (ICN-AO 1434). 


\section{Description}

Male (based on MNRJ 17948)

Measurements. $\mathrm{CL}=1.62, \mathrm{AL}=3.06, \mathrm{CW}=2.63, \mathrm{AW}=4.31, \mathrm{Fe} \mathrm{IV}=2.94, \mathrm{Ti} \mathrm{IV}=2.38$.

Dorsum (Figs 27, 28A). Dorsal scutum beta-shaped, with symmetrical mid-bulge. Areas I, III and posterior margin with two paramedian tubercles. Lateral margins with irregular row of minute granules at

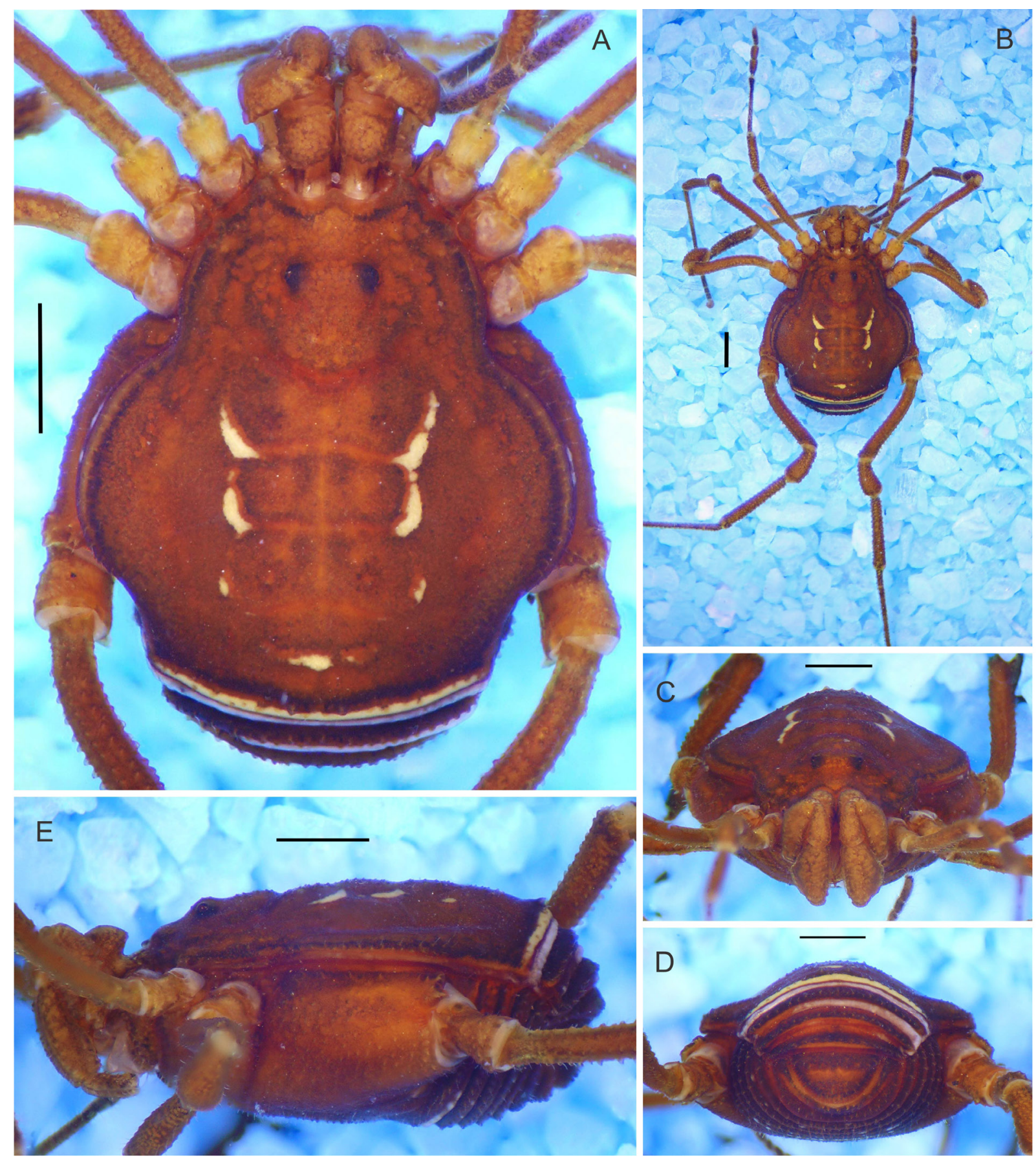

Fig. 27. Eulibitia scalaris (Sørensen in Henriksen, 1932) comb. nov., $\widehat{\sigma}$ (MNRJ 17948), habitus. A. Dorsal view. B. Panoramic, dorsal view. C. Frontal view. D. Posterior view. E. Lateral view. Scale bars: $1 \mathrm{~mm}$. 

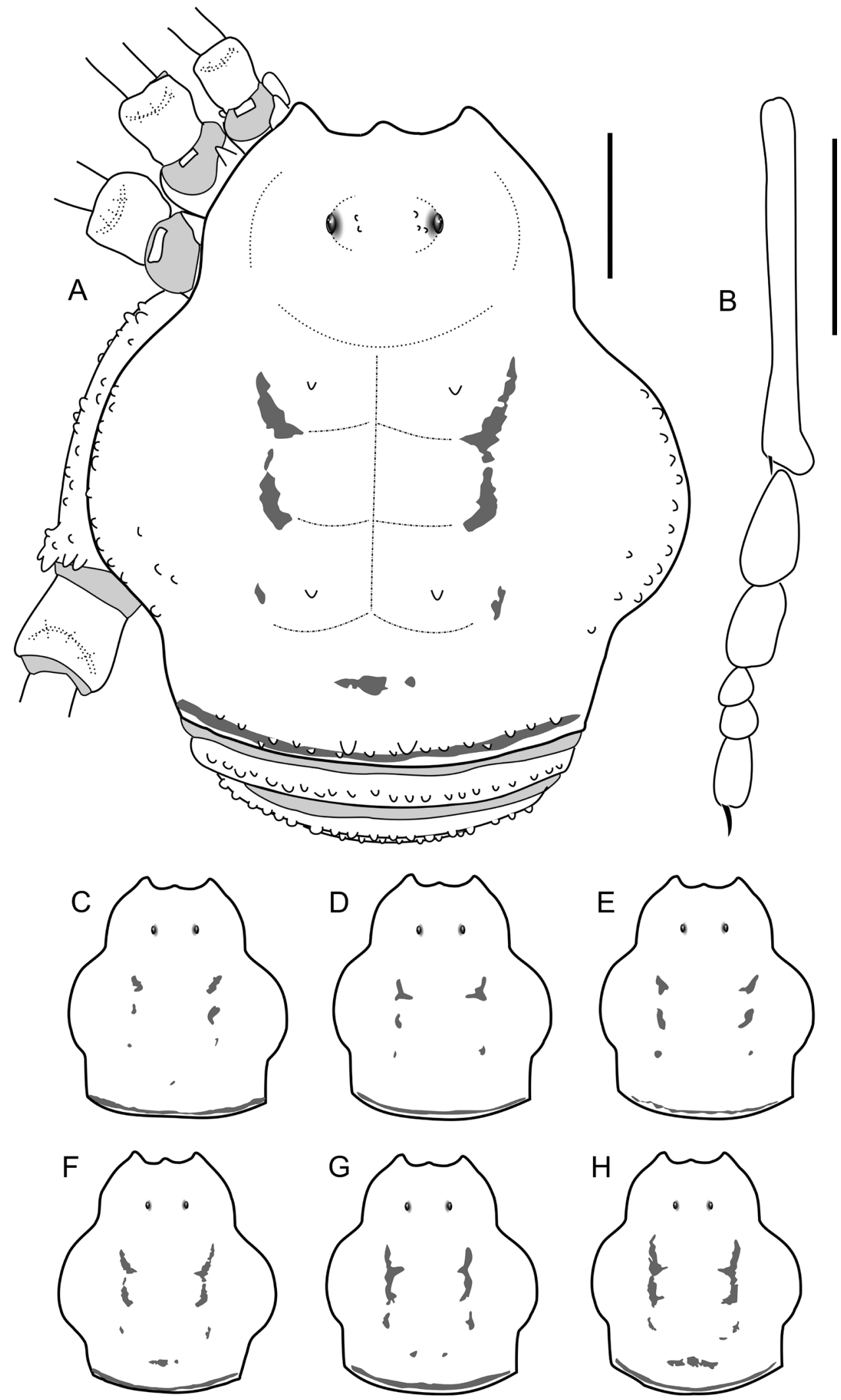

Fig. 28. Eulibitia scalaris (Sørensen in Henriksen, 1932) comb. nov. (MNRJ 17948). A. §, habitus, dorsal view. B. Left metatarsus and tarsomeres of leg I, prolateral view. C-F. Variation of spot pattern on dorsal scutum. C-E, G-H: 우. F: О․ Scale bars: $1 \mathrm{~mm}$. 
mid-bulge. Posterior margin of scutum with row of small tubercles. Tergites with row of small tubercles and anal operculum finely granular.

VenTER (Fig. 27D-E). Free sternites finely granular; coxae II-IV finely and uniformly granular; coxa I with longitudinal row of tubercles and smooth area corresponding to lace area of pedipalp.
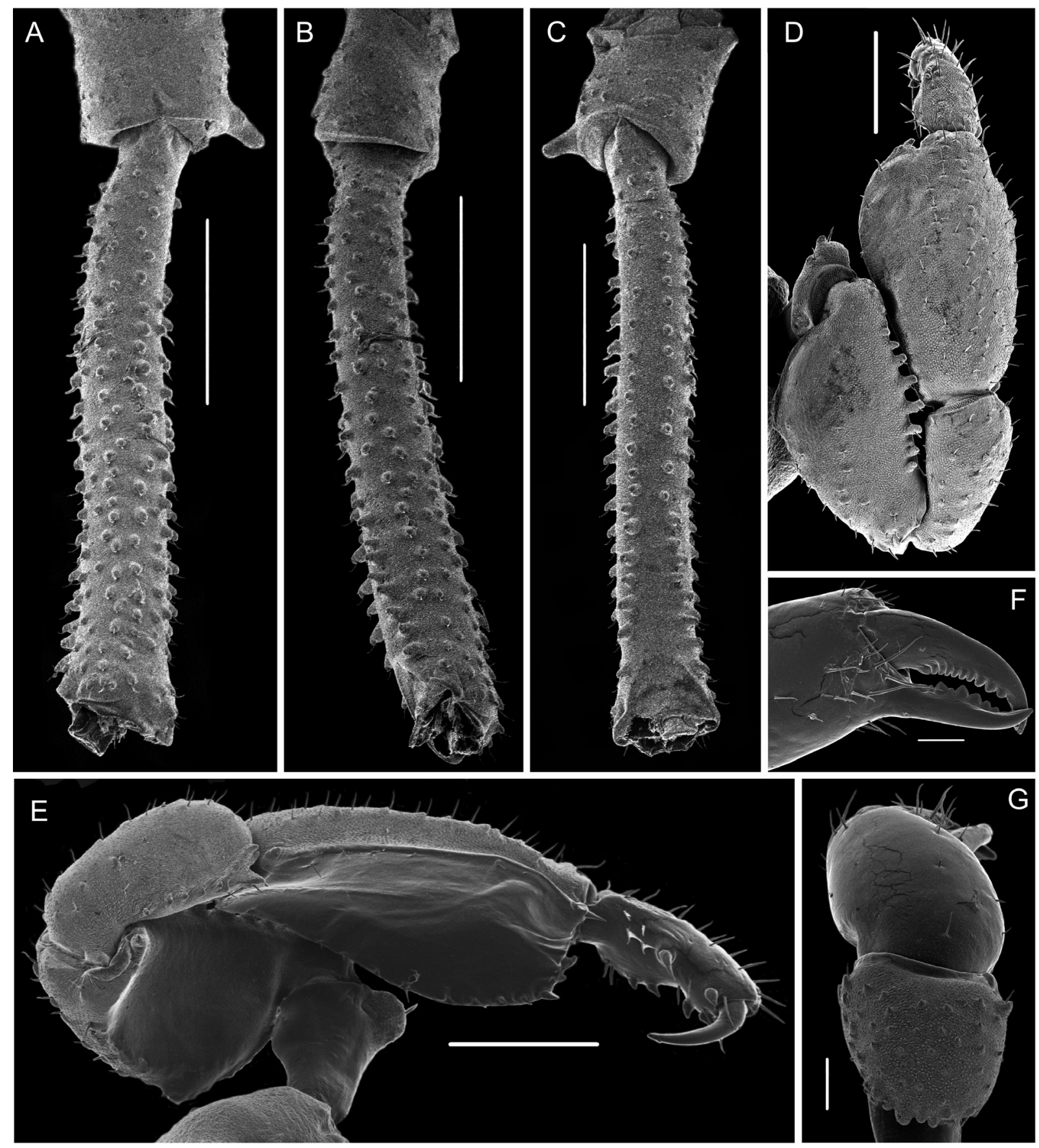

Fig. 29. Eulibitia scalaris (Sørensen in Henriksen, 1932) comb. nov., $\widehat{\jmath}$ (ICN-AO 1208). A. Trochanter and femur of leg IV, dorsal view. B. Same, prolateral view. C. Same, ventral view. D. Left pedipalpus, ectal view. E. Same, mesal view. F. Fingers of the hand of left chelicera, dorsal view. G. Left chelicera, dorsal view. Scale bars: A-C $=1 \mathrm{~mm} ; \mathrm{D}-\mathrm{E}=500 \mu \mathrm{m} ; \mathrm{F}-\mathrm{G}=200 \mu \mathrm{m}$. 
Chelicerae (Fig. 29F-G). Basichelicerite uniformly covered with tubercles of different sizes, some basal and one mesodistal larger; movable finger with row of ten tubercles; fixed finger with four tubercles, decreasing in size from basal to distal part of finger.

Pedipalps (Fig. 29D-E). Trochanter with strong ventral apophysis. Femur with pronounced dorsal keel, with ventral row of eight setiferous tubercles and mesodistal process. Patella with mesal keel formed by five small tubercles and large one distally. Shallow slit along tibia mesal surface, separating dorsal and ventral sides.

Legs (Figs 28B, 29A-C). Coxa IV granulated, with small clavi inguines, larger in females. Trochanter IV with small retro-distal apophysis. Femur IV substraight, with two longitudinal ventral rows of small

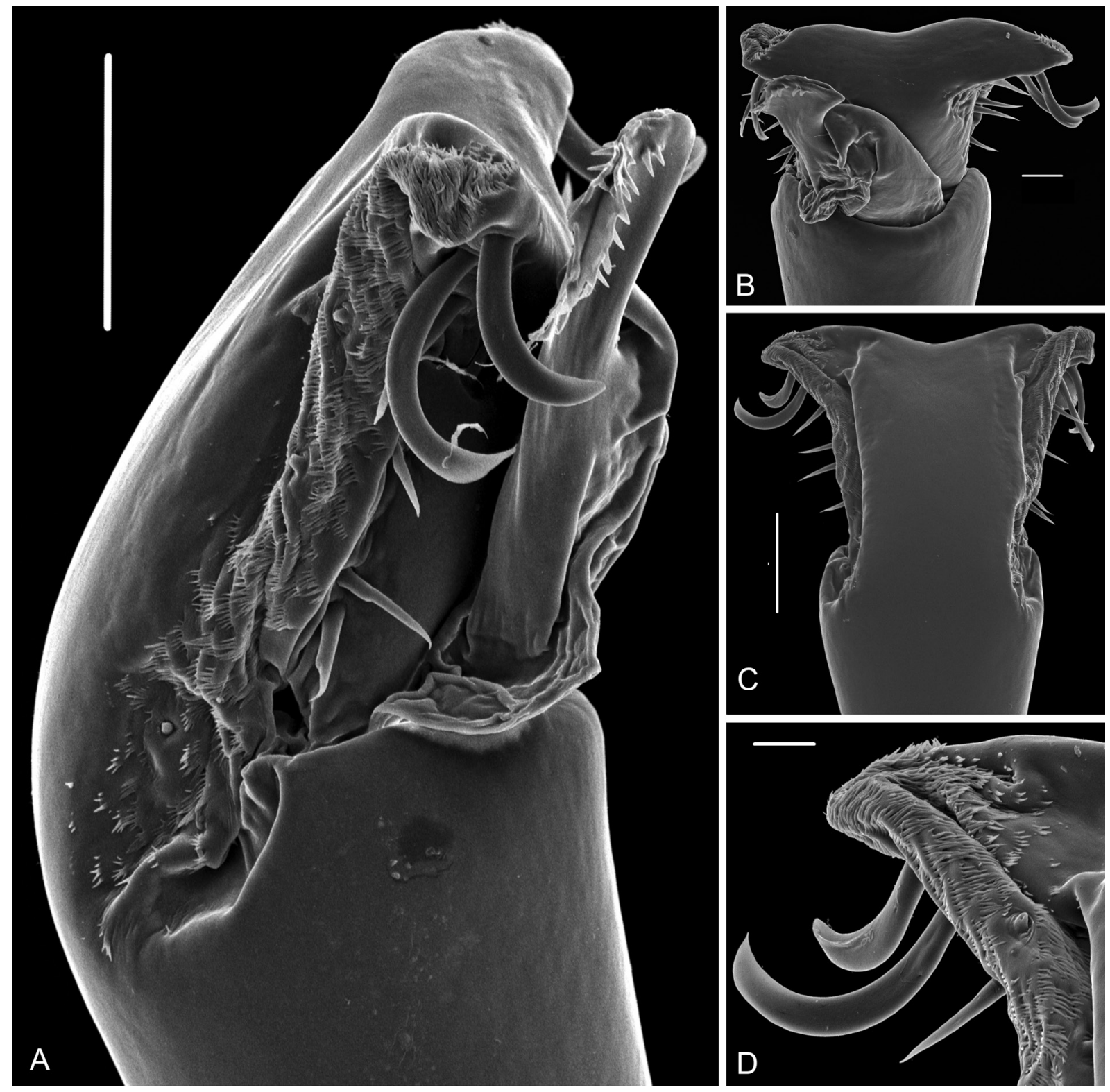

Fig. 30. Eulibitia scalaris (Sørensen in Henriksen, 1932) comb. nov., § (ICN-AO 1208), distal part of penis. A. Lateral view. B. Dorsal view. C. Ventral view. D. Detail of MS C, MS D1, MS E1 and microsetae, ventral view. Scale bars: $A, C=50 \mu \mathrm{m} ; \mathrm{B}=20 \mu \mathrm{m} ; \mathrm{D}=10 \mu \mathrm{m}$. 


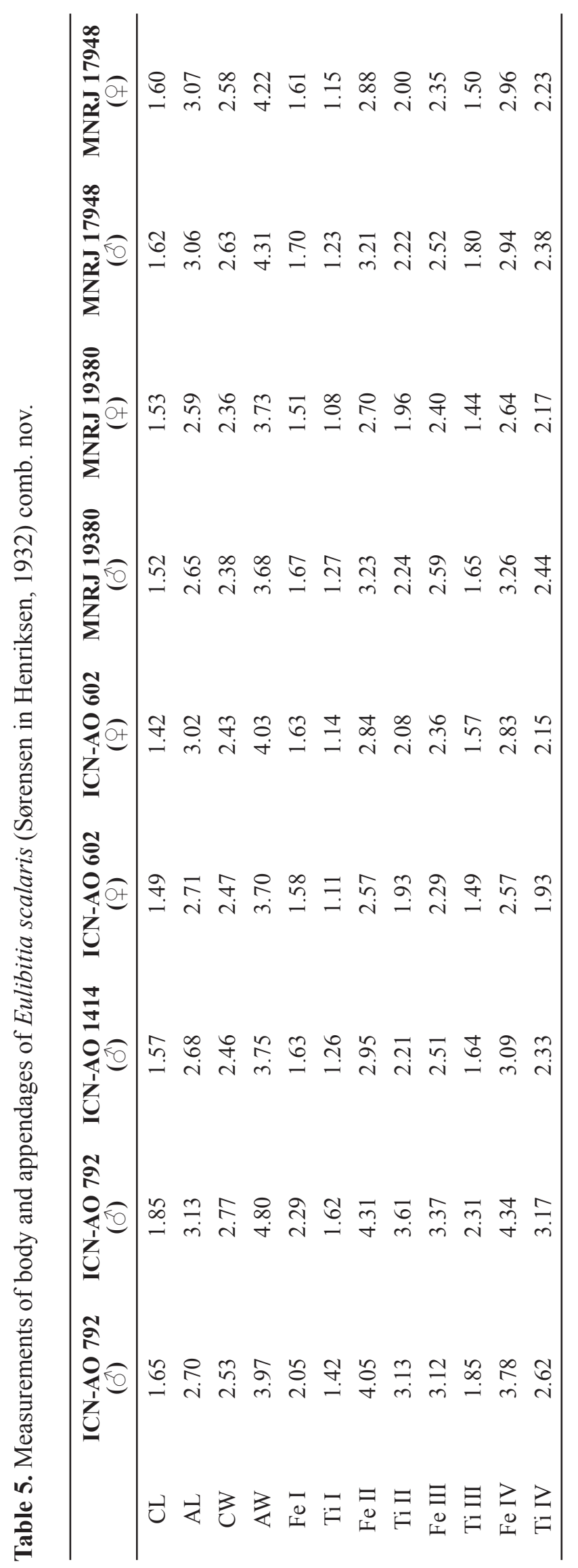


tubercles along entire length. Patella IV substraight, with small setiferous tubercles. Tarsal counts: $5-5 / 10-10 / 6-6 / 6-7$.

Color (Fig. 27). Body and appendages color background 40 (Strong Reddish Brown) mottled in 44 (Dark Reddish Brown), ladder mask 104 (Pale Greenish Yellow). Trochanters and tarsomeres 83 (Brilliant Yellow).

Genitalia (Fig. 30). VP of penis trapezoidal, narrower basally, with distal border concave; dorsal apophysis of glans subsquare to rounded, wattle of stylus long. Shapes and organization of macrosetae as follows: MS C1-C2 large, curved and flat; MS D1-D2 large and straight; MS A1-A2 large, straight, cylindrical, located in basal middle of ventral plate; MS B and MS E1-E2 ventral, very small, immersed in microsetae. MS B most basal MS. Microsetae confined to lateral margins of ventral plate.

\section{Variation}

Pattern of yellow spots as in Fig. 28C-H. Tubercles of pedipalpal femur vary in number from 5 to 8 . Tarsal counts: $5-6 ; 7-12 ; 6-7 ; 6-7$. Variation of measurements is given in Table 5.

\section{Female}

With larger clavi inguines and longer coda than males (Fig. 28F-G). Males with thicker basitarsus (but not notably swollen) (Fig. 28B).

\section{Distribution}

E. scalaris occurs in the WWF ecoregions: (1) Magdalena Valley montane forests (NT0136), tropical and subtropical moist broadleaf forest biome, in Cundinamarca and Boyacá Departments, (2) Magdalena Valley dry forests (NT0221), tropical and subtropical dry broadleaf forest biome, in Tolima Department, and (3) Northern Andean páramo (NT1006), montane grassland and shrubland biome, in Cundinamarca and Boyacá Departments (Fig. 33).
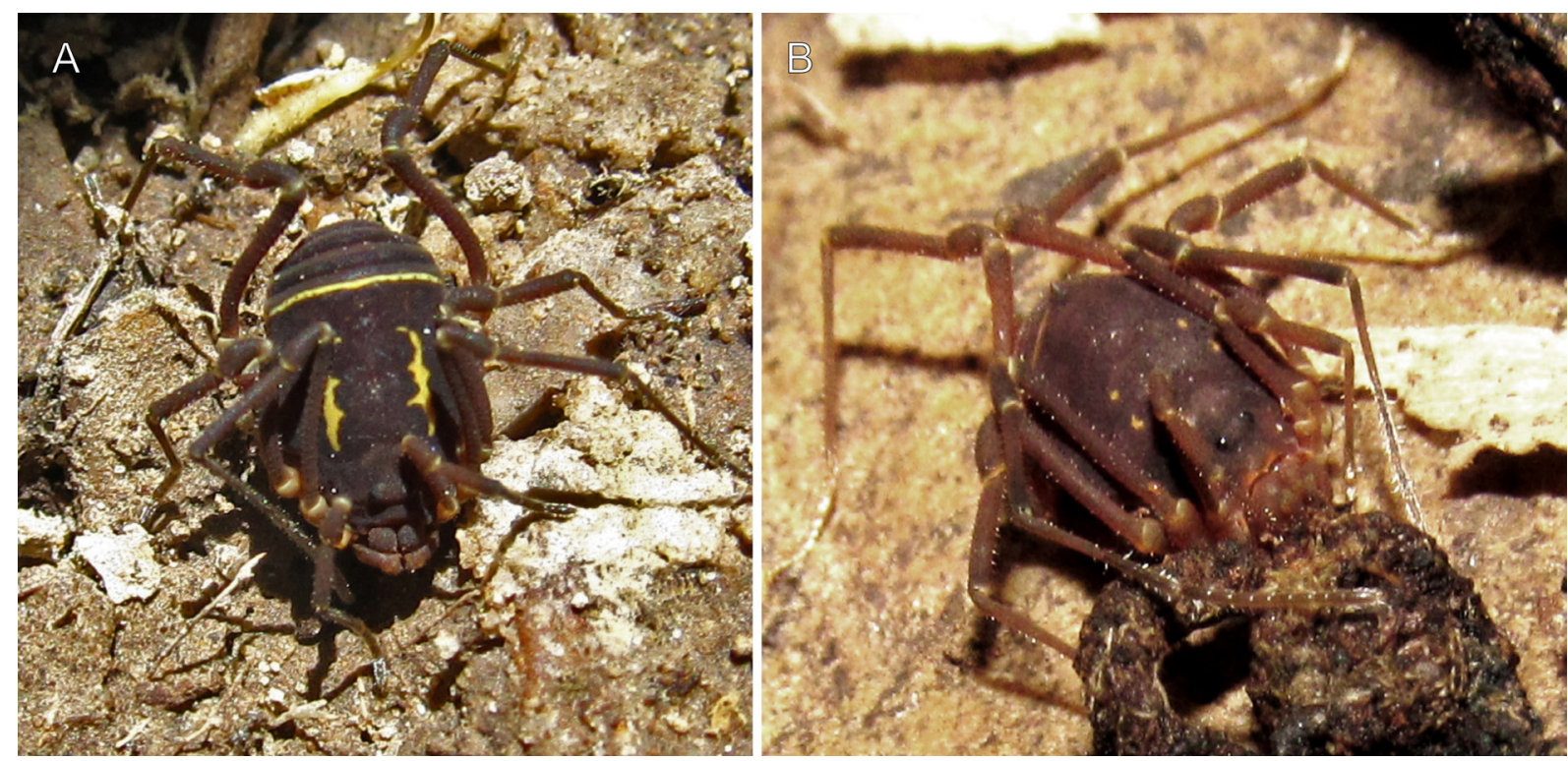

Fig. 31. Living specimens. A. Eulibitia scalaris (Sørensen in Henriksen, 1932) comb. nov. (ICN-AO 1208), photograph by Andrés García, Arcabuco, Boyacá Department. B. Eulibitia pollux sp. nov., photograph by M. Medrano, Choachi, Cundinamarca Department. 


\section{Remarks}

Goodnight \& Goodnight (1943) described Acromares lateralis and placed it in that genus because they thought that the outstanding tubercles of the dorsal scutum were localized in area IV. However, examination of a photograph of the type material allows us to conclude that the tubercles are on the posterior margin of the scutum instead of on area IV and to recognize this species as a synonym of E. scalaris comb. nov.

Ambatoiella Mello-Leitão, 1943

Ambatoiella Mello-Leitão, 1943: 8; Kury 2003: 37 (junior subjective synonym of Vonones Simon, 1879 according to Goodnight \& Goodnight (1953: 60); synonymy disclaimed by Kury (2003); type species: Ambatoiella vigilans Mello-Leitão, 1943, by original designation).

Ambatoiella sexpunctata (Roewer, 1914) comb. nov.

Eulibitia sexpunctata Roewer, 1914: 127, pl. 13, fig 4.

Eulibitia sexpunctata - Roewer 1923: 299, fig. 321.

\section{Type material}

\section{Holotype}

ECUADOR: $\curvearrowright$, Guayas, Guayaquil (MNHN, examined).

\section{Paratype}

ECUADOR: 1 ○े, Riobamba (SMF RI/473 - 32, examined by photograph).

\section{Remarks}

This species is morphologically similar to Ambatoiella vigilans Mello-Leitão, 1943 by: (1) coxa IV only apically visible in dorsal view, and (2) coda large, about one third the length of DS. Likewise, the type localities of the two species are only $50 \mathrm{~km}$ apart from each other and are in the same mountain range. There is a strong possibility that they are male and female of the same species; however, we decided to maintain them as separate species until further analyses have been carried out.

Cosmetinae incertae sedis

Eulibitia annulipes Roewer, 1912

Eulibitia annulipes Roewer, 1912: 18.

Eulibitia annulipes - Roewer 1923: 298.

\section{Type material}

\section{Holotype}

COLOMBIA: $\widehat{\gamma}$, Tolima [according to label; incorrectly reported in the original description as "Ecuador (Guayaquil)"] (SMF RI/447 - 32, examined by photograph).

\section{Remarks}

The size of the body, shape of the outline of DS and the strong and uniform granularity of the scutum do not correspond to the genus Eulibitia. It was impossible to fit this species in any known genus; the most similar genus is Ambatoiella based on the alpha-shaped scutum, but an analysis of the type material or topotypes is needed to allow an accurate decision. 


\section{Discussion}

\section{Morphology}

Eulibitia seems to be a good example of the conservative external morphology of Cosmetidae mentioned above in the Introduction; the variations in shape of outline of DS and the morphology of pedipalpus, legs and chelicera are extremely subtle, and the delimitation of species may be difficult. Nonetheless, some characteristics have proved useful to differentiate species of Eulibitia, such as: (1) the armature of the scutal areas, commonly useless for diagnosing genera; (2) the armature of femur IV; and (3) the occurrence of clavi inguines.

The morphology of the reproductive organs in Gonyleptoidea has been shown to be very valuable in phylogenetic analyses (i.e., Kury \& Villarreal 2015; Cruz-López \& Francke 2015), and has been well explored in detail for some species (i.e., Bennett \& Townsend 2013; Walker \& Townsend 2014; Townsend et al. 2015). In Cosmetidae, however, the genital morphology is somewhat uniform, if compared with Gonyleptidae for example. In the species of Eulibitia only the size of MS D2 varies. It is probable that the genital morphology in Cosmetidae is more useful in defining genera or suprageneric groups (e.g., the enormous caruncle of the stylus in Libitia, the small MS A in Ambatoiella and the long VP in Discosomaticinae such as Gryne).

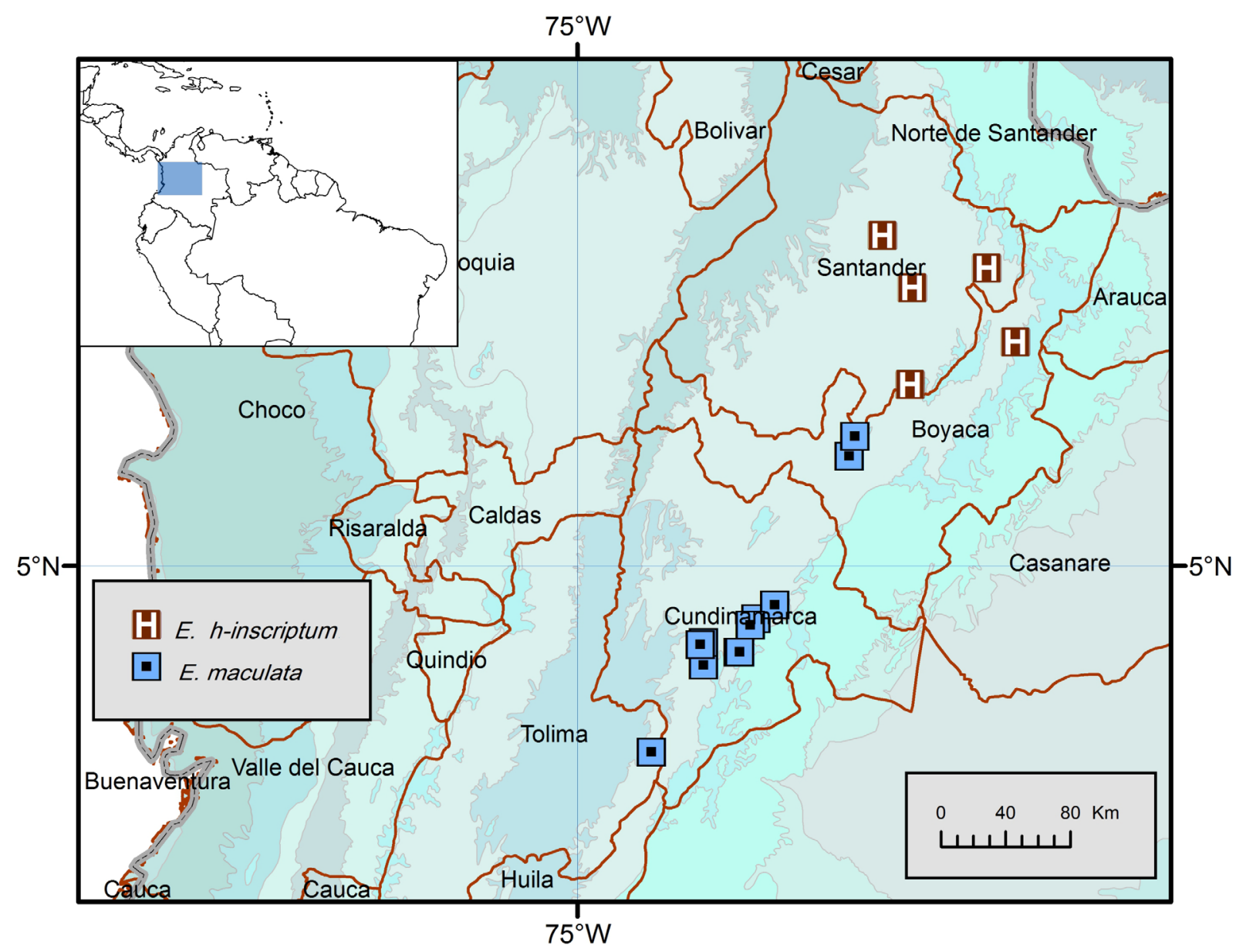

Fig. 32. Northern Andes in Colombia, showing localities for Eulibitia maculata Roewer, 1912 and E. h-inscriptum (Mello-Leitão, 1941) comb. nov. Colored patches on the background represent WWF ecoregions. 


\section{Relationships of Eulibitia}

The Andean genera Ambatoiella, Libitia and Libitiella seem to be related to Eulibitia in having: (1) legs short and femur IV sometimes slightly curved; (2) body almost unarmed, with tubercles or spines short or minute in the scutal areas; (3) absence of marked sexual dimorphism, such as hypertelic chelicera in males; (4) basitarsomeres of leg I of males clearly thicker than distitarsomeres (except in Ambatoiella, where they are monomorphic, equally sturdy), but not enormously enlarged as in other more distantly related genera (e.g., Cumbalia Roewer, 1963, Fig 2); (5) macrosetae D1 closer to C2 than to D2; and (6) presence of a soft latero-distal area on VP (at macrosetae D1) which may be sunken, forming a noticeable notch (Figs 4A, E, 14A, 18A, 22A, 26A, 30B). Although no phylogenetic analyses have been carried out in Cosmetidae, these genera seem to form a natural group. Cumbalia shows other differences to the core of the Eulibitia-like Andean genera, such as: (1) the basalmost basitarsomere is much longer than the second one (as opposed to being subequal, regardless of whether counting two or three articles) and (2) Mt III and IV of male tapering (as opposed to ordinarily cylindrical rods).

However, some features allow us to diagnose Eulibitia in contrast to these other Andean genera: (1) shape of DS and lateral projections of protoglyphs (Fig. 1); (2) armature of basichelicerite (almost smooth in Libitia, Fig. 4C-D); (3) presence of teeth on movable and fixed fingers of cheliceral hand (absent in Ambatoiella, Fig. 4B, F); (4) absence of pectination formed by strong proventral spiniform

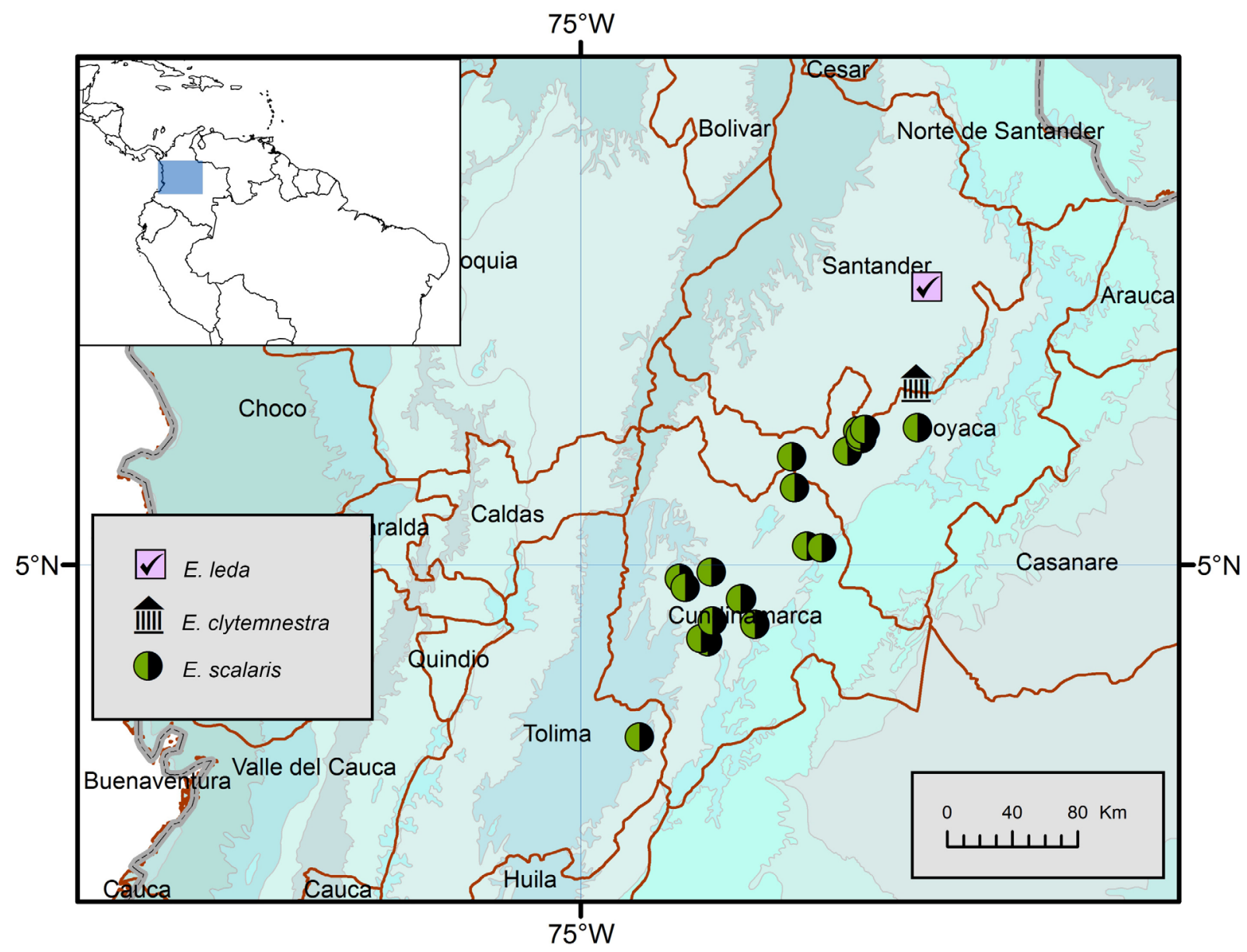

Fig. 33. Northern Andes in Colombia, showing localities for Eulibitia leda sp. nov., E. clytemnestra sp. nov. and E. scalaris (Sørensen in Henriksen, 1932) comb. nov. Colored patches on the background represent WWF ecoregions. 
apophyses on distal 3/4 of Cx IV in male (present in Ambatoiella); (5) Mt I 15\% to 30\% longer than Ta I (as opposed to subequal in the others); (6) normal-sized basitarsomeres of legs III-IV (much thicker in males of Libitia, Fig. 2); (7) basitarsomeres of leg IV trimerous as in Ambatoiella (5 articles in Eulibitia and 6-7 in Cumbalia); and (8) size of macrosetae A1-A2 of penis ventral plate (short in Ambatoiella, Fig. 4A, E).

On the other hand, the genus Eulibitia also seems to be related to the Amazonian genus Taito, which exhibits common characteristics like beta-type DS, clavi inguines sometimes present, slight sexual dimorphism and a transverse yellow stripe on the posterior margin of the scutum. However, this genus differs from Eulibitia by: (1) presence of equuleus in DS; (2) posterior margin of scutum never with paramedian tubercles; (3) anal operculum of males sometimes with robust tubercles; (4) legs long and slender; and (5) dorsal apophysis of coxa IV large and directed backwards; in addition to this are the features mentioned in Kury \& Barros (2014) as possible synapomorphies, such as the calli (latero-distal projections of the truncus), which are not present in species of Eulibitia (Fig. 26).

\section{Remarks on distribution}

The genus Eulibitia is confined to the northern Andean montane forests of Colombia, with a marked preference for the Magdalena Valley montane forest (NT0136) and Northern Andean páramo (NT1006)

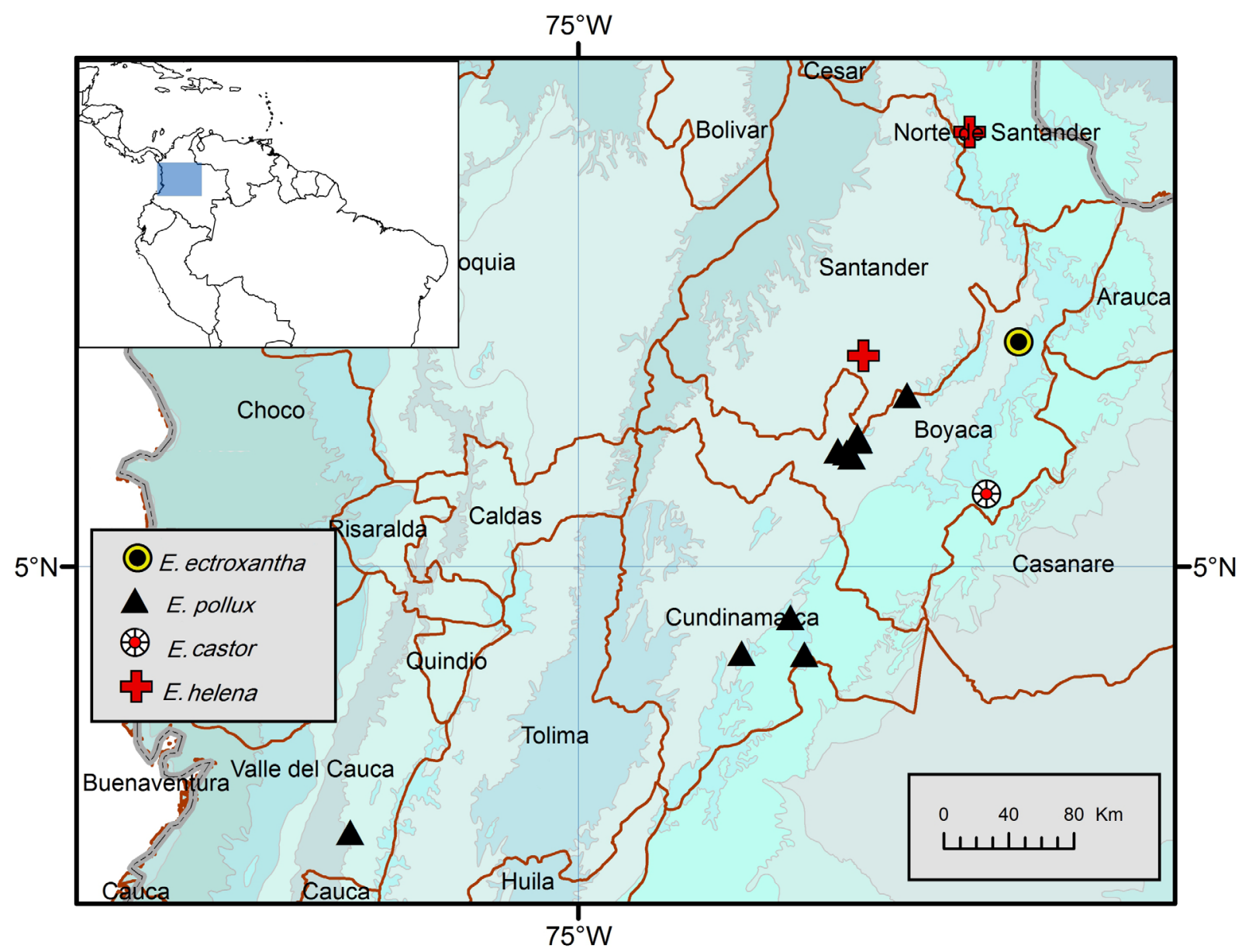

Fig. 34. Northern Andes in Colombia, showing localities for Eulibitia ectroxantha (Mello-Leitão, 1941) comb. nov., E. pollux sp. nov., E. castor sp. nov. and E. helena sp. nov. Colored patches on the background represent WWF ecoregions. 
ecoregions, in two biomes: tropical and subtropical moist broadleaf forests, and montane grasslands and shrubland.

Species of Eulibitia are widely sympatric, which is why they are presented here on three maps (Figs 32-34) to avoid a muddled overlap. Eulibitia scalaris is the most abundant species in collections and the most widespread, occurring in three different biomes corresponding to three ecoregions: tropical and subtropical moist broadleaf forests (Magdalena Valley montane forests - NT0136), tropical and subtropical dry broadleaf forests (Magdalena Valley dry forests - NT0221) and montane grasslands and shrubland (Northern Andean páramo - NT1006).

There is a single point of occurrence of E. pollux sp. nov. in the Cauca Valley montane forest ecoregion (NT0109), in Palmira (Valle del Cauca), a place isolated from the other records of the species and even the genus. The marked preference of species of Eulibitia for the Northern Andean páramo (NT1006) ecoregion, contrasting with the lowland city Palmira (1040 m a.s.1.) and the Magdalena River and the Central Cordillera as physical barriers, suggest that this record should be considered doubtful.

\section{Acknowledgements}

We thank the following individuals and institutions: Osvaldo Villarreal (MNRJ) for important help and constructive criticism from the beginning of this project; Amanda Mendes (Universidade do Estado do Rio de Janeiro) and Alcimar Carvalho (MNRJ) for comments on draft versions; Andrés Garcia and Carla Barros for diverse help and support in the lab; Ricardo Pinto-da-Rocha (Universidade de São Paulo) kindly shared his photographs of the SMF and ZMH types; Elise-Anne Leguin provided a photograph of a holotype in MNHN; Janet Beccaloni kindly assisted ABK during visits to BMNH in 2011 and 2013. Stack images of Sørensen's types in BMNH were created under supervision of Dr Vladimir Blagoderov. The collection curators Claudia Medina (IAvH) and Eduardo Flórez (ICN) made the specimens examined here available. Amanda Veiga, Camila Simões and Beatriz Cordeiro (MNRJ) and Roger Silva (Fundação Oswaldo Cruz) assisted with the SEM photographs. The Conselho Nacional de Desenvolvimento Científico e Tecnológico (CNPq), responsible for the Programa de Estudantes Convênio de PósGraduação (PEC-PG), made a trip by MM to Brazil possible through an MSc scholarship. The Programa de Apoio à Pós-graduação (PROAP) paid for the SEM photographs. This study was supported by grant \#562149/2010-4 (PROTAX-OPESC project), scholarship \#302116/2010-9 (PQ-AMMA project) from $\mathrm{CNPq}$ to $\mathrm{ABK}$. The final draft benefited from the criticism of two anonymous referees.

\section{References}

Acosta L.E., Pérez-González A. \& Tourinho A.L. 2007. Methods and techniques of study: Methods for taxonomic study. In: Machado G., Pinto-da-Rocha R. \& Giribet G. (eds) Harvestmen, the Biology of Opiliones: 494-505. Harvard University Press, Cambridge, Massachusetts.

Bennett M.K. \& Townsend V. 2013. Reproductive morphology of three species of neotropical harvestmen (Opiliones, Laniatores, Gonyleptoidea). Journal of Morphology 274: 1415-1424. https://doi.org/10.1002/jmor.20191

Caetano D.S. \& Machado G. 2013. The ecological tale of Gonyleptidae (Arachnida, Opiliones) evolution: phylogeny of a Neotropical lineage of armoured harvestmen using ecological, behavioural and chemical characters. Cladistics 29 (6): 589-609. https://doi.org/10.1111/cla.12009

Cruz-López J.A. \& Francke O.F. 2015. Cladistic analysis and taxonomic revision of the genus Karos Goodnight \& Goodnight, 1944 (Opiliones, Laniatores, Stygnopsidae). Zoological Journal of the Linnean Society 175: 827-891. https://doi.org/10.1111/zoj.12299 
DaSilva M.B. \& Gnaspini P. 2009. A systematic revision of Goniosomatinae (Arachnida: Opiliones: Gonyleptidae), with a cladistic analysis and biogeographical notes. Invertebrate Systematics 23: 530624. https://doi.org/10.1071/IS09022

Ferreira C.P. \& Kury A.B. 2010. A review of Roquettea, with description of three new Brazilian species and notes on Gryne (Opiliones, Cosmetidae, Discosomaticinae). Zoological Science 27: 697-708. https://doi.org/10.2108/zsj.27.697

Flórez E. \& Sánchez H. 1995. La diversidad de los arácnidos en Colombia — aproximación inicial. In: Rangel O. (ed.) Colombia, Diversidad Biótica, I: 327-372. Instituto de Ciencias naturales, UN, Inderena, Fes, Fen. Santafé de Bogotá.

GeoNames. 2015. GeoNames [online]. Available from http://www.geonames.org/ [accessed 15 Jun. 2015].

Goodnight C.J. \& Goodnight M.L. 1942a. New and little known Phalangida from Mexico. American Museum Novitates 1163: 1-16.

Goodnight C.J. \& Goodnight M.L. 1942b. Phalangids from Central America and the West Indies. American Museum Novitates 1184: 1-23.

Goodnight C.J. \& Goodnight M.L. 1943. Phalangida from South America. American Museum Novitates 1234: $1-19$.

Goodnight C.J. \& Goodnight M.L. 1953. The opilionid fauna of Chiapas, Mexico, and adjacent areas (Arachnoidea, Opiliones). American Museum Novitates 1610: 1-81.

Hadley A. 2015. CombineZP [online]. Available from https://en.freedownloadmanager.org/Windows-PC/CombineZP-FREE.html [accessed 4 Oct. 2017].

Harvey M.S. 2002. The neglected cousins: What do we know about the smaller arachnid orders? Journal of Arachnology 30 (2): 357-372. https://doi.org/10.1636/0161-8202(2002)030[0357:tncwdw]2.0.co;2

Henriksen K.L. 1932. Descriptiones Laniatorum (Arachnidorum Opilionum Subordinis) fecit William Sørensen. Opus posthumum recognovit et edidit Kai L. Henriksen. Det Kongelige Danske Videnskabernes Selskabs skrifter, Naturvidenskabelig og Mathematisk Afdeling, Series 9, 3 (4): 197-422.

Jaffer, A. 2001-. NBS/ISCC centroids. In: Color-Name Dictionaries [online].

Available from http://people.csail.mit.edu/jaffer/Color/Dictionaries\#nbs-iscc [accessed 12 Jan. 2017].

Kury A.B. 1990. Synonymic notes on Mitobates Sund. with redescription of the type species $M$. conspersus (Perty) (Opiliones: Gonyleptidae). Bulletin of the British Arachnological Society 8 (6): 194200.

Kury A.B. 2003. Annotated catalogue of the Laniatores of the New World (Arachnida, Opiliones). Revista Ibérica de Aracnología, Volumen especial monográfico 1: 1-337.

Kury A.B. 2013. Order Opiliones Sundevall, 1833. In: Zhang Z.-Q. (ed.) Animal Biodiversity: An Outline of Higher-Level Classification and Survey of Taxonomic Richness (Addenda 2013). Zootaxa 3703 (1): 27-33. https://doi.org/10.11646/zootaxa.3703.1.7

Kury A.B. 2014. Why does the Tricommatinae position bounce so much within Laniatores? A cladistic analysis, with description of a new family of Gonyleptoidea (Opiliones, Laniatores). Zoological Journal of the Linnean Society 172: 1-48. https://doi.org/10.1111/zoj.12165

Kury A.B. 2016a. Classification of Opiliones. Museu Nacional/UFRJ website [2000-] [online]. Available from http://www.museunacional.ufrj.br/mndi/Aracnologia/opiliones.html [accessed 15 Oct. 2016]. 
Kury A.B. 2016b. A classification of the penial microsetae of Gonyleptoidea (Opiliones: Laniatores). Zootaxa 4179 (1): 144-150. https://doi.org/10.11646/zootaxa.4179.1.13

Kury A.B. \& Alonso-Zarazaga M.-A. 2011. Addenda and corrigenda to the "Annotated catalogue of the Laniatores of the New World (Arachnida, Opiliones)". Zootaxa 3034: 47-68.

Kury A.B. \& Barros C.M. 2014. A new genus and eight new species of Amazonian cosmetines (Opiliones, Laniatores, Cosmetidae). Zoological Studies 53: 1-46. https://doi.org/10.1186/s40555-014-0024-4

Kury A.B. \& Medrano M. 2016. Review of terminology for the outline of dorsal scutum in Laniatores (Arachnida, Opiliones). Zootaxa 4097 (1): 130-134. https://doi.org/10.11646/zootaxa.4097.1.9

Kury A.B. \& Orrico V.G. 2006. A new species of Lacronia Strand, 1942 from the highlands of Rio de Janeiro (Opiliones, Gonyleptidae, Pachylinae). Revista Ibérica de Aracnologia 13: 147-153.

Kury A.B. \& Pinto-da-Rocha R. 2007. Cosmetidae Koch, 1839. In: Pinto-da-Rocha R., Machado G. \& Giribet G. (eds) Harvestmen: The Biology of the Opiliones: 182-185. Harvard University Press, London and Cambridge, Massachusetts.

Kury A.B. \& Villarreal O.M. 2015. The prickly blade mapped: Establishing homologies and a chaetotaxy for macrosetae of penis ventral plate in Gonyleptoidea (Arachnida, Opiliones, Laniatores). Zoological Journal of the Linnean Society 174: 1-46. https://doi.org/10.1111/zoj.12225

Medrano M. \& Kury A.B. 2016. Characterization of Platymessa with redescription of the type species and a new generic synonymy (Arachnida, Opiliones, Cosmetidae). Zootaxa 4085 (1): 52-62.

https://doi.org/10.11646/zootaxa.4085.1.2

Mello-Leitão C.F. de 1926. Notas sobre Opiliones Laniatores sul-americanos. Revista do Museu Paulista 14: 327-383.

Mello-Leitão C.F. de 1932. Opiliões do Brasil. Revista do Museu Paulista 17 (2): 1-505.

Mello-Leitão C.F. de 1933. Notas sobre os opiliões do Brasil descritos na obra póstuma de Sörensen: "Descriptiones Laniatorum". Boletim do Museu Nacional 9 (1): 99-114.

Mello-Leitão C.F. de 1935. Algumas notas sobre os Laniatores. Archivos do Museu Nacional 36 (4): 87-116.

Mello-Leitão C.F. de 1941. Alguns opiliões novos da Colômbia. Anais da Academia Brasileira de Ciências 13 (3): 165-171.

Mello-Leitão C.F. de 1943. Arácnidos recogidos en el Ecuador y el Perú por la Señora H.E. Frizell Don. Comunicaciones zoologicas del Museo de Historia natural de Montevideo 1 (5): 1-8.

Olson D.M., Dinerstein E., Wikramanayake E.D., Burgess N.D., Powell G.V.N., Underwood E.C., D'amico J.A., Itoua I., Strand H.E., Morrison J.C., Loucks C.J., Allnutt T.F., Ricketts T.H., Kura Y., Lamoreux J.F., Wettengel W.W., Hedao P. \& Kassem K.R. 2001. Terrestrial ecoregions of the world: A new map of life on Earth. BioScience 51: 933-938.

https://doi.org/10.1641/0006-3568(2001)051[0933:TEOTWA]2.0.CO;2

Pinto-da-Rocha R. \& Hara M. 2011. Redescription of Platygyndes Roewer 1943, a false Gonyleptidae, (Arachnida, Opiliones, Cosmetidae). ZooKeys 143: 1-12. https://doi.org/10.3897/zookeys.143.1916

Pinto-da-Rocha R., Bragagnolo C., Marques F.P.L. \& Antunes Jr M. 2014. Phylogeny of harvestmen family Gonyleptidae inferred from a multilocus approach (Arachnida: Opiliones). Cladistics 30 (5): 519-539. https://doi.org/10.1111/cla.12065

Piza Jr S.T. de. 1942. A respeito da sistemática de alguns opiliões. Revista Brasileira de Biologia 2 (4): 403-416. 
Roewer C.F. 1912. Die Familie der Cosmetiden Opiliones-Laniatores. Archiv für Naturgeschichte, Abteilung A 78 (10): 1-122.

Roewer C.F. 1914. Arachnida Opiliones. In: Académie des Sciences (ed.) Mission du Service Géographique de l'Armée pour la Mesure d'un Arc de Méridien équatorial en Amérique du Sud: 121141. Vol. 10 (Entomologie, Botanique), Issue 2 (Opiliones. Diptères. Myriapodes). Gauthier-Villars et Cie, Paris.

Roewer C.F. 1923. Die Weberknechte der Erde. Systematische Bearbeitung der bisher bekannten Opiliones. Gustav-Fisher, Jena.

Roewer C.F. 1928. Weitere Weberknechte II. (2. Ergänzung der Weberknechte der Erde, 1923.) Abhandlungen der Naturwissenschaftlichen Verein zu Bremen 26 (3): 527-632.

Roewer C.F. 1963. Opiliones aus Peru und Colombien. (Arachnida Arthrogastra aus Peru V.) Senckenbergiana Biologica 44 (1): 5-72.

Soares B.A.M. 1945. Opiliões da coleção do Museu Nacional do Rio de Janeiro. Arquivos de Zoologia do Estado de São Paulo 4 (9): 341-394.

Soares H.E.M. 1970. Novas espécies de opiliões da Região Amazônica (Opiliones, Cosmetidae, Gonyleptidae, Phalangiidae, Stygnidae). Revista Brasileira de Biologia 30 (3): 323-338.

Soares H.E.M. \& Soares B.A.M. 1985. Opera Opiliologica Varia XXII. Opiliones Gonyleptidae. Naturalia 10: 157-200.

Strand E. 1942. Miscellanea nomenclatoria zoologica et Paleontologica X. Folia Zoologica et Hydrobiologica 11 (1): 386-402.

Townsend V., Bertram M.S. \& Milne M.A. 2015. Variation in ovipositor morphology among laniatorean harvestmen (Arachnida: Opiliones). Zoomorphology 134 (3): 487-497.

https://doi.org/10.1007/s00435-015-0269-4

Walker E. \& Townsend V. 2014. Ovipositor morphology of cosmetid harvestmen (Arachnida, Opiliones, Laniatores): A new source of informative characters. Journal of Morphology 275 (12): 1376-1385. https://doi.org/10.1002/jmor.20310

Weidner H. 1959. Die entomologischen Sammlungen des Zoologischen Staatsinstitut und Zoologischen Museum Hamburg. I. Teil. Pararthropoda und Chelicerata I. Mitteilungen aus dem hamburgischen zoologischen Museum und Institut 57: 89-142.

Manuscript submitted: 3 November 2016

Manuscript accepted: 13 February 2017

Manuscript published: 11 October 2017

Subject editor: Rudy Jocqué

Desk editor: Danny Eibye-Jacobsen

Printed versions of all papers are also deposited in the libraries of the institutes that are members of the EJT consortium: Muséum national d'Histoire naturelle, Paris, France; Botanic Garden Meise, Belgium; Royal Museum for Central Africa, Tervuren, Belgium; Natural History Museum, London, United Kingdom; Royal Belgian Institute of Natural Sciences, Brussels, Belgium; Natural History Museum of Denmark, Copenhagen, Denmark; Naturalis Biodiversity Center, Leiden, the Netherlands; Museo Nacional de Ciencias Naturales-CSIC, Madrid, Spain; Real Jardín Botánico de Madrid CSIC, Spain. 